\title{
Tapping the Earth's Natural Heat
}

By Wendell A. Duffield,

John H. Sass, and

Michael L. Sorey 


\section{DISCLAIMER}

This report was prepared as an account of work sponsored by an agency of the United States Government. Neither the United States Government nor any agency Thereof, nor any of their employees, makes any warranty, express or implied, or assumes any legal liability or responsibility for the accuracy, completeness, or usefulness of any information, apparatus, product, or process disclosed, or represents that its use would not infringe privately owned rights. Reference herein to any specific commercial product, process, or service by trade name, trademark, manufacturer, or otherwise does not necessarily constitute or imply its endorsement, recommendation, or favoring by the United States Government or any agency thereof. The views and opinions of authors expressed herein do not necessarily state or reflect those of the United States Government or any agency thereof. 


\section{DISCLAIMER}

Portions of this document may be illegible in electronic image products. Images are produced from the best available original document. 


\section{Conversion Factors}

For readers who wish to convert measurements from the metric system of units to the inch-pound system, the conversion factors are listed below.

\begin{tabular}{|rcl|}
\hline Multiply & By & To obtain \\
\hline hectacre & 2.47 & acre \\
square meter & 10.76 & square foot \\
kilometer & .6214 & mile \\
metric ton & 1.102 & short ton (2,000 pounds) \\
metric ton & .9842 & long ton (2,240 pounds) \\
cubic kilometer & .2399 & cubic mile \\
liter per second & 15.85 & gallon per minute \\
kilogram per second & 27.273 & pound per minute \\
\hline
\end{tabular}

To convert from degree Celsius $\left({ }^{\circ} \mathrm{C}\right)$ to degree Fahrenheit $\left({ }^{\circ} \mathrm{F}\right)$, multiply the ${ }^{\circ} \mathrm{C}$ value by 1.8 and add 32 to the resulting value.

\section{U.S. DEPARTMENT OF THE INTERIOR BRUCE BABBITT, Secretary}

\section{U.S. GEOLOGICAL SURVEY}

Gordon P. Eaton, Director

Text and illustrations edited by Carolyn Donlin

Graphics prepared by Sara Boore and Susan Mayfield

Book designed by Sara Boore and Susan Mayfield

Any use of trade, product, or firm names in this publication is for descriptive purposes only and does not imply endorsement by the U.S. Covernment

UNITED STATES GOVERNMENT PRINTING OFFICE, WASHINGTON: 1994

Free on application to

USGS Map Distribution

Box 25286, Building 810

Denver Federal Center

Denver, CO 80225

\section{Library of Congress Cataloging-in-Publication Data}

Duffield, Wendell A.

Tapping the earth's natural heat / by Wendell A. Duffield, John H. Sass, and Michael L. Sorey.

p. $\quad \mathrm{cm}$. - (U.S. Geological Survey Circular ; 1125. Public issues in earth science)

Includes bibliographical references.

Supt. of Docs. no.: I 19.412:1125

1. Geothermal resources. I. Sass, J.H. (John Harvey), $1937-$

II. Sorey, M.L. III. Title.

IV. Series: U.S. Geological Survey circular; 1125. V. Series: U.S. Geological Survey circular. Public issues in earth science.

GB1199.5.D84 1994 94-27386

333.8 '8-dc20 


\section{Foreword}

Our Nation is powered largely by energy produced from the cornbustion of fossil fuelscoal, petroleum, and natural gas. In all likelihood, these conventional sources of energy will be depleted within the next few hundred years, and possibly much sooner. Moreover, the extraction and combustion of fossil fuels cause major environmental harm. A vital issue facing the world therefore is how to meet our ever-increasing energy demands in an economically feasible and environmentally sensitive way. There is no simple solution. In the short term, we can delay the depletion of conventional energy sources by energy conservation practiced at all consumer levels, but in the long term, an effective strategy must include greater use of sustainable and relatively nonpolluting energy sources—such as geothermal, solar, wind, ocean tides, and biomass-in the total energy generating mix.

This circular describes the potential for geothermal energy, the naturally occurring heat within the Earth, to contribute to such a mix. For thousands of years, people have benefited from the use of heat emitted at the Earth's surface through hot springs and steam vents. Modern drilling technology has allowed us to increase our use of the abundant hot water steam produced deep within the Earth. Indeed, geothermal energy is the most w sustainable, nonconventional alternative to fossil fuels today. It is highly be used in the generation of electricity, as well as in a host of direct-use ap. space heating and various industrial processes. Geothermal energy suitable $t$ generation is found mostly in the Western United States, although direct-use $a_{\perp}$ possible in almost all parts of the country. As an energy source, it is much clean duce and use than energy from fossil fuels, including even natural gas.

The U.S. Geological Survey has been and remains active in conducting field anc raboratory studies to better understand the distribution, origin, and abundance of geothermal resources. A principal goal is to identify and evaluate the geothermal resources of the Nation. An ancillary goal is to monitor the behavior of natural geothermal features in national parks and other protected recreational lands; such monitoring allows early detection and mitigation of changes that might result from nearby commercial development.

If fully harnessed using current technologies, geothermal resources of the United States could supply as much as 10 percent of the Nation's energy demand. With advances in technology, the contribution of geothermal energy might be increased substantially. As we look to the future, a major challenge to geoscientists, geothermal developers, government officials, and citizens is to work together to realize the full potential of geothermal energy. The U.S. Geological Survey is pleased to summarize information related to developing geothermal energy while minimizing its environmental impact. The quality of life in the future depends on timely actions to harness geothermal and other sustainable energy resources in an environmentally sound manner.

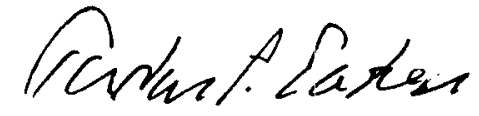

Director, U.S. Geological Survey 


\section{Tapping the Earth's Natural Heat}

2 Introduction

3 Acknowledgments

Section One

6 Geothermal Energy as a Natural Resource

6 Global Distribution

10 Comparison with Other Natural Resources

Section Two

14 Geothermal Environments and Energy Potential

15 Hydrothermal Systems

15 Electrical-Grade Systems: Power Generation

23 Warm-Water Systems: Direct Use

27 Geopressured Systems

27 "Dry" Geothermal Environments

\section{Section Three}

32 Geothermal Studies at the U.S. Geological Survey

34 Assessing the Nation's Geothermal Resources

40 Geothermal-Energy Development

40 Relevance to Other Geologic Studies

\section{Section Four}

42 Geothermal Energy and Environmental Impact

\section{Section Five}

50 A Look Toward the Future

50 Supporting New Exploration

53 Searching for Deeper Hydrothermal Systems

53 Developing Reservoir-Enhancement Technology

54 Geothermal Energy In Our Nation's Future

56 Suggested Additional Reading

Appendixes

58 1. Geothermal Developments in the United States as of 1990

60 2. Selected Principal Geothermal Studies of the U.S. Geological Survey

62 3. Scientific Drilling in Geothermal Systems 


\section{Special Topics}

4 Geothermal Then-Geothermal Now

8 Magma, Volcanoes, and Geothermal Energy

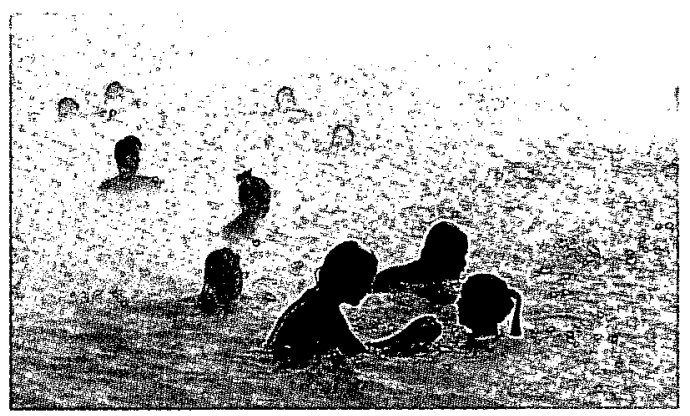

12 Geothermal Energy and the Ring of Fire

18 Tapping the Geothermal Potential of the Great Basin

20 The Geysers, California-World's Largest Producer of Geothermal Electricity

22 Electricity from Moderate-Temperature Hydrothermal Systems

24 Geothermal Space Heating - A Boon to Iceland's Economy

26 Direct-Use Geothermal Applications-Paris, France, and Klamath Falls, Oregon

28 "Mining" the Earth's Heat

33 Hot Springs "Remember" Their Deeper, Hotter Origins

36 "Seeing” Beneath the Earth's Surface

38 Geothermal Resource Assessment-How Much of the Earth's Heat Can Be Tapped?

43 Geothermal Energy is Cleaner than Conventional Energy Sources

44 Geothermal Development in Hawaii-Continuing Debate

46 Yellowstone National Park-Threatened by Nearby Geothermal Development?

48 Long Valley Caldera-Monitoring Hydrologic Changes Caused by Geothermal Development
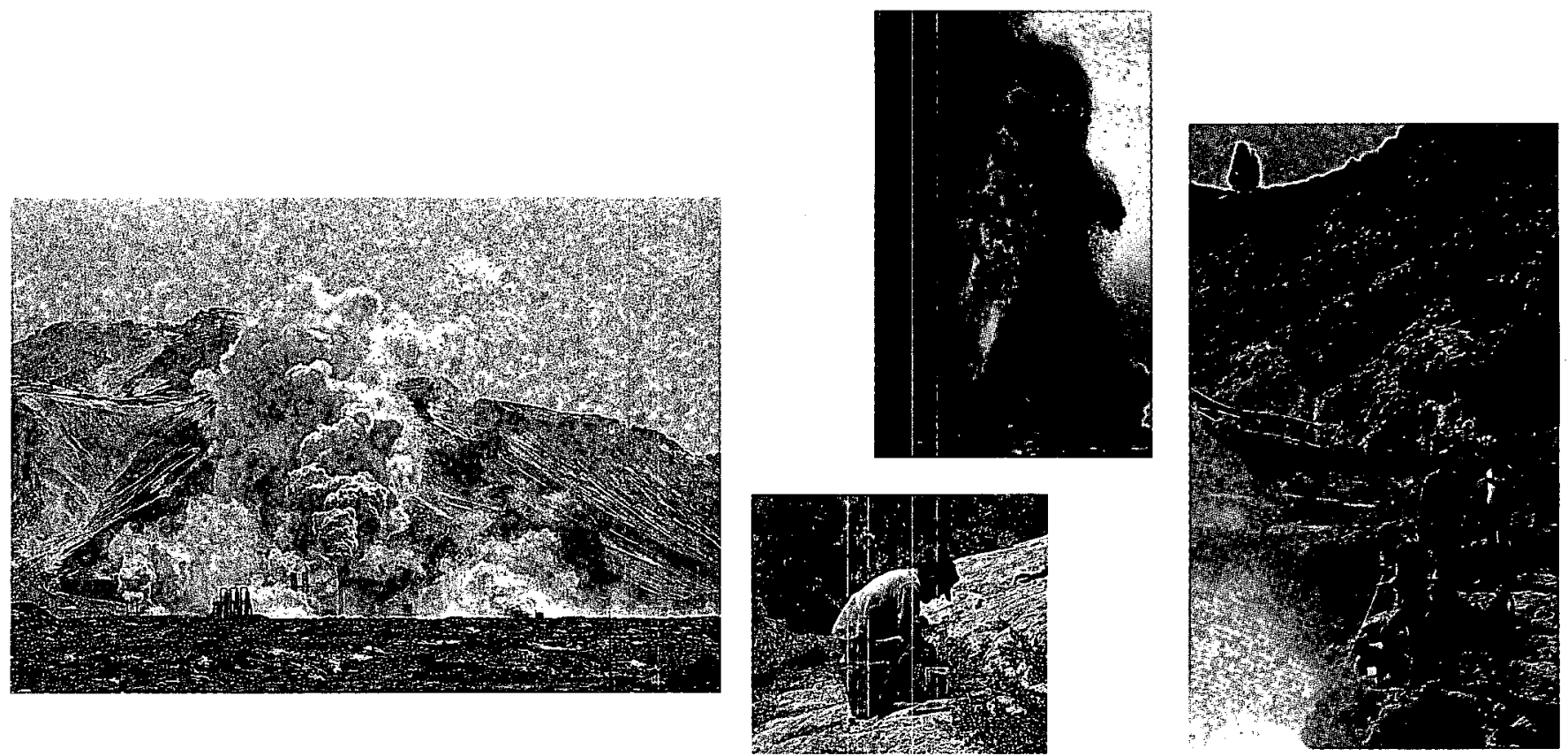


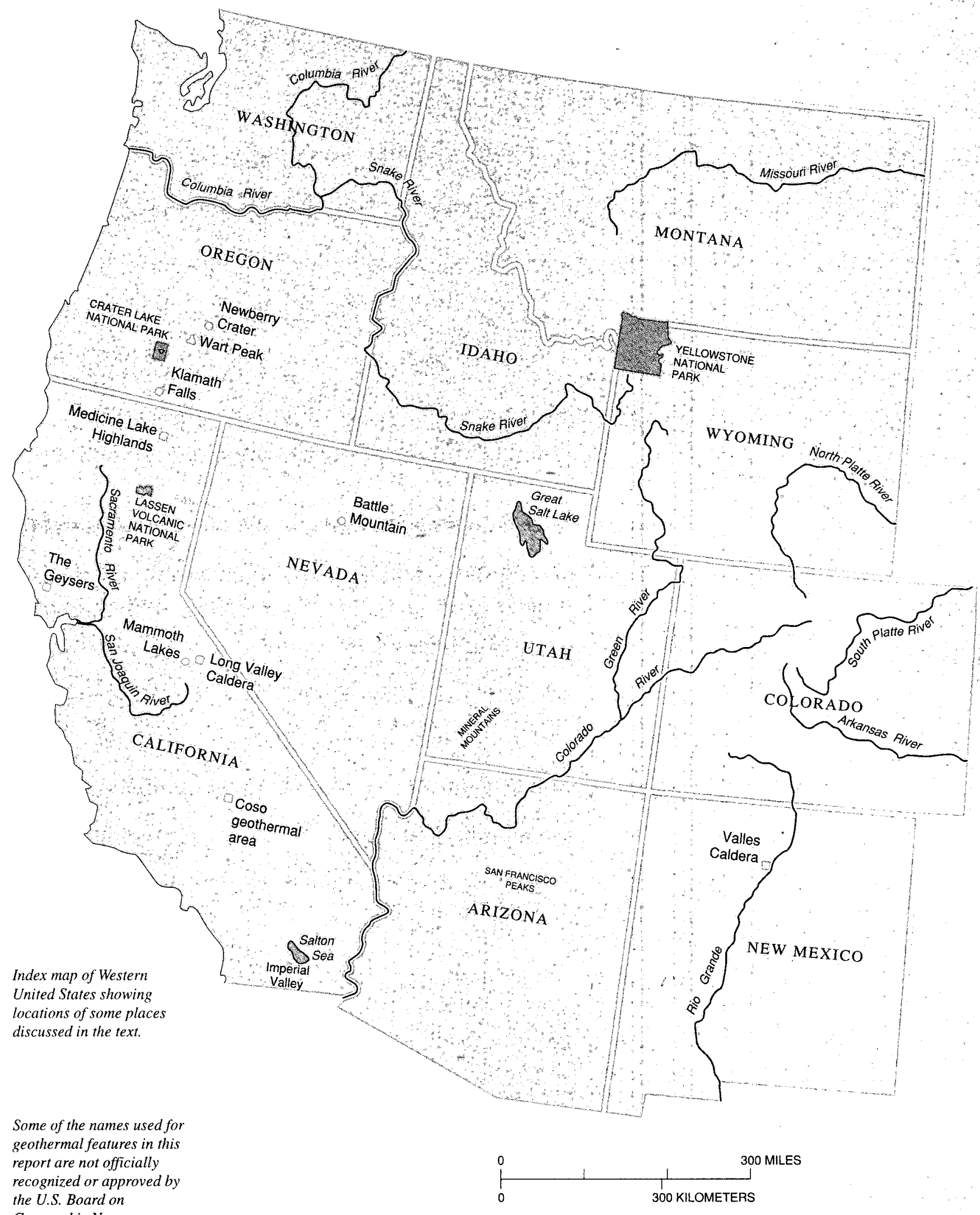

Geographic Names. 


\section{Introduction}

\section{The Earth's}

natural heat is

cleaner than

conventional

sources of

energy and there

is less environ-

mental impact

associated with

its use.
$\mathrm{T}$ he Earth is a bountiful source of heat. It continuously produces heat at depth, primarily by the decay of naturally radioactive chemical elements (principally uranium, thorium, and potassium) that occur in small amounts in all rocks. This deep heat then rises toward the cooler surface, where scientists can measure the rate of its escape through the Earth's crust. The annual heat loss from the Earth is enormous-equivalent to 10 times the annual energy consumption of the United States and more than that needed to power all nations of the world, if it could be fully harnessed! Even if only 1 percent of the thermal energy contained within the uppermost 10 kilometers of our planet could be tapped, this amount would be 500 times that contained in all oil and gas resources of the world. The Earth's natural heat is cleaner than conventional sources of energy (coal, oil, and gas), and there is less environmental impact associated with its use.

How might we benefit from this vast amount of thermal energy beneath our feet? Where, by what means, and how much of the Earth's natural heat can be tapped? These are critically important questions as we approach the 21 st century, during which the global population is expected to greatly exceed 6 billion and the world's fossil-fuel resources will be further depleted, if not exhausted. Faced with this prospect, both the public and private sectors are working toward more fully utilizing the Earth's abundant thermal energy - commonly called geothermal energy.

For centuries, people have enjoyed the benefits of geothermal energy available at hot springs, but it is only through technological advances made during the 20th century that we can tap this energy source in the subsurface and use it in a variety of ways, including the generation of electricity. To sustain world civilization as we know it, we must start depending more on energy sources other than fossil fuels (coal, oil, and gas) in addition to reducing the per capita amount of energy we use. Through a combination of scientific research, innovative engineering, and economic incentives, geothermal energy could become one of several cost-effective alternatives to nonrenewable and polluting energy sources, especially in meeting nontransportation demands, both in the United States and abroad.

A skeptic might question the wisdom of devoting much national effort to geothermal energy development, especially because many experts believe that geothermal heat can contribute-at most—only about 10 percent to the Nation's energy supply using current technologies. However, achievable advances in exploration and heat-extraction technology could increase this contribution substantially. But whether or not such advances are made, we should 
not forget the wise proverb about "not putting all eggs in one basket." The United States is still powered mostly by energy from fossil fuels; at present, about half of our oil is imported. We have apparently forgotten the hard lessons of the 1970's oil embargo, during which we experienced serious disruptions to daily life and the national economy when the supply of imported petroleum was interrupted. Just as a judicious investor does not put all capital into a single stock, a prudent nation will attempt to diversify its energy supply from multiple resources.

The primary purpose of this publication is to provide information that will help the reader understand how, where, and to what extent geothermal energy can contribute to our Nation's needs. We (1) describe the distribution and nature of geothermal energy; (2) review the common types of geothermal systems that provide useful energy using current technology; (3) consider potential geothermal resources that could be tapped with new technologies; and (4) summarize the role of earth-science information in assessing and tapping the geothermal resources of the United States, and in providing technical assistance to developing countries in studies of their geothermal fields.

\section{ACKNOWLEDGMENTS}

We thank Carolyn Donlin, Marianne Guffanti, Steve Ingebritsen, Patrick Muffler, Henry Spall, and Robert Tilling for helping improve the content and presentation of this publication, and many other colleagues in government, academia and the private sector for helpful collaborations on many aspects of geothermal energy during the past three decades. The assistance of Susan Priest, Liz Colvard, and Rick Blakely in the preparation of the illustrations is greatly appreciated. We also wish to thank Sara Boore and Susan Mayfield for the work they did in creating and preparing the final illustrations for publication.

The annual heat loss from the Earth is enormous-equivalent to 10 times the annual energy consumption of the United States and more than that needed to power all nations of the world, if it could be fully harnessed! 


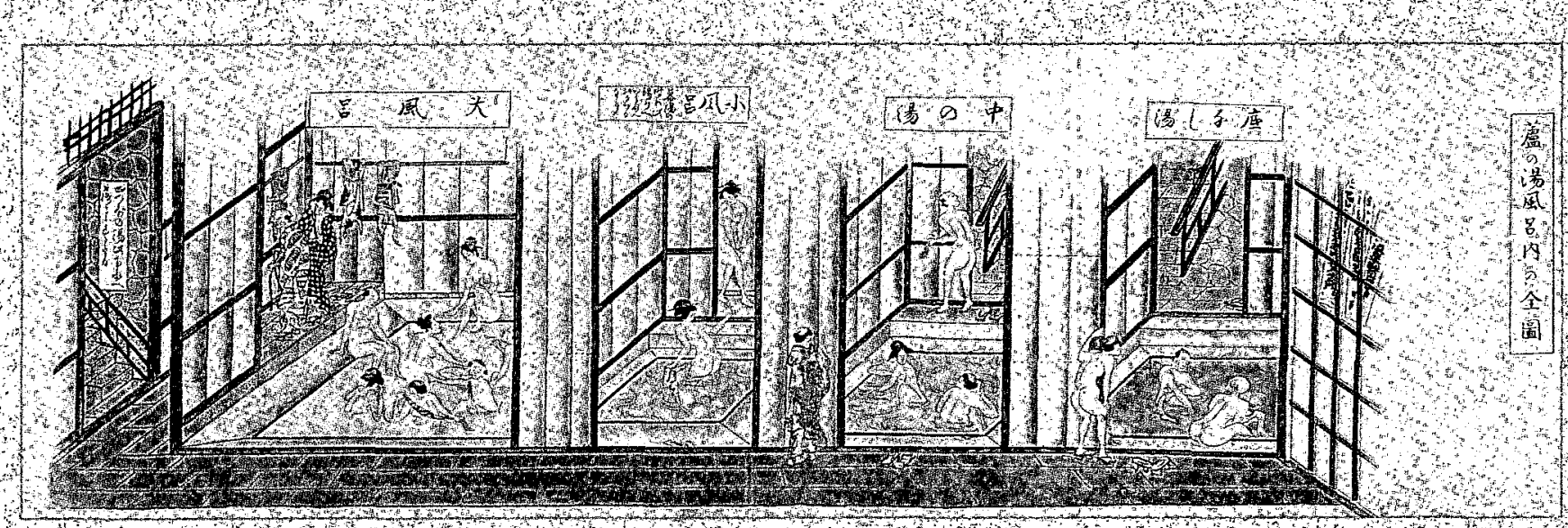

Scene from a Japa nese spa shows one of the early uses of geo thermal energy Ant work was originally published ina guide book called "Seven Hot Springs of Hakonen written and painted anonymously in 181 by a writer whose pen name was Bunsou and an artist whose pen name was Rouka Courtesy of Hakone Museüm of Folk Culture in Hakone City Japan

\section{Geothermal Then-Geothermal Now}

\section{GEOTHERMALIN ANCIENT TIMES}

Long before recorded history, some ancient peoples must have been aware of geothermal features such as hissing steam vents enupting geysers, boiling mud pots, and bubbling hot springs One can only speculate on their reactions to such impressive natural phenomena, but some combination of fear, awe and appreciation seems likely $\mathrm{By}$ the time of recorded history hot springs and other geothermal features were being üsed by people for food preparation and for bathing. The geothermally heated spas of the ancient Greeks Romans and Japanese have been mitated throughout history, and today their modern counterparts attract many visitors for recreational and medical reasons

Prehistoric and early historical use of geothermal features was effectively limited to those found at the Earth s surface. With rare exception such features produce water or steam with temperatures of less than $100^{\circ} \mathrm{C}$ (the boiling point of water at sea evel), the ir relatively low temperatures restrict the variety of possible uses Lack of knowledge and technical limita toon prohibited any attempt to develop deeper, hotter geothermalenergy still, many early civilizations benefited from the geothermal resources with which they were provided by nature.

\section{GEOTHERMALNOW}

With $20^{\text {in }}$ century technology drills can penetrate thousands of meters into the Earth in search of geothermal resources. Such drilling has resulted in the discovery of geothermal water as hot as $400^{\circ} \mathrm{C}$, which can provide a resource of high-pressure steam to drive turbine generators at the Earth's surface. The traditional, ancient uses of geothermal water continue to have considerable scenic and recreational value, but the present day capability to produce high-temperature fluid through drilled wells opens the door to diverse utilization of geother mal energy over a broad range of temperatures Information gathered rom measurements made during flow testing of geothermal wells can ndicate how much power they can provide Typical commercial geothermal well are rated between 5 and 8 megawatts electric (1 megawatt $=1,000$ kilowatts $=1$ million watts $)$ 


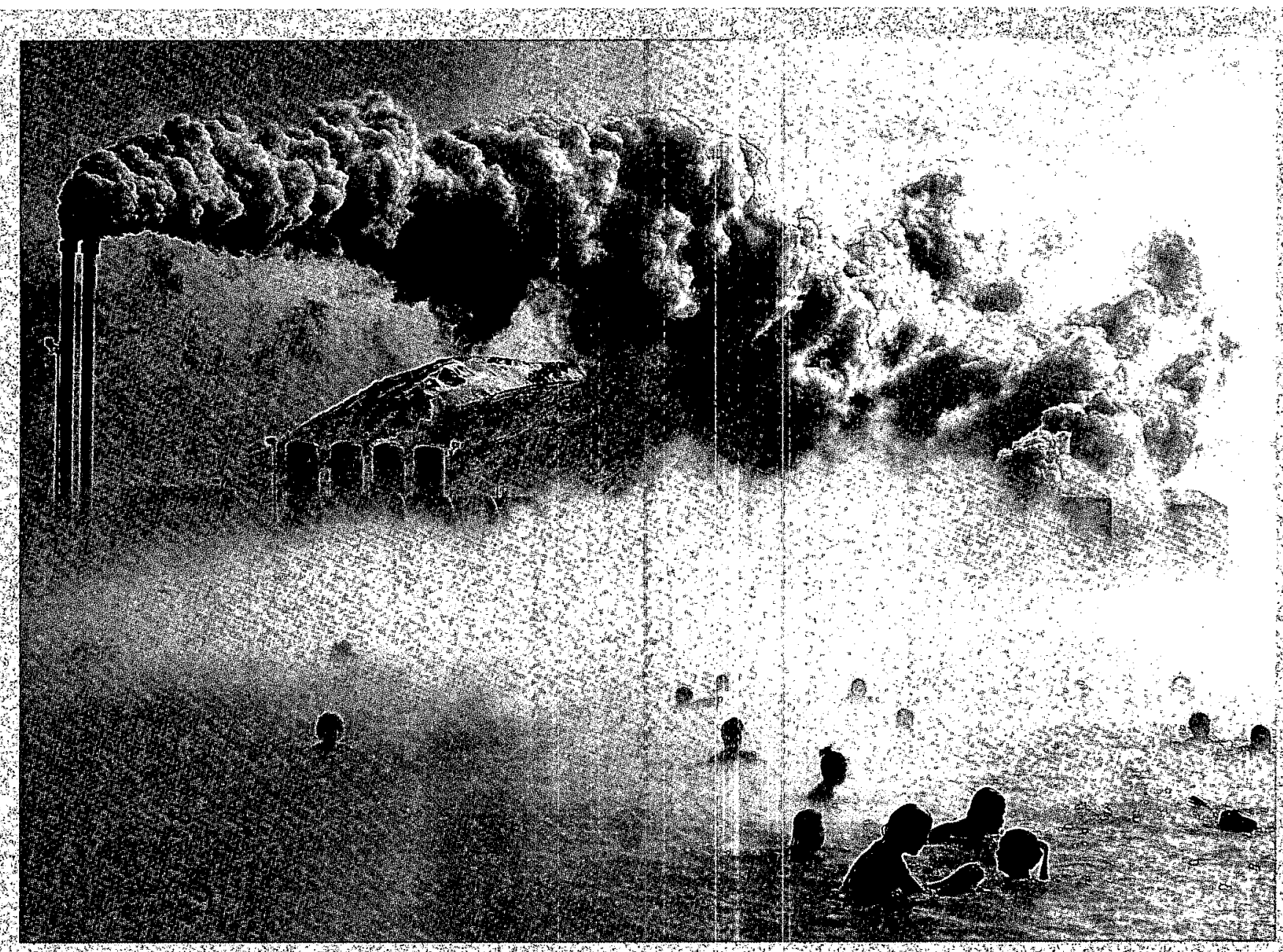

Research and development have also shown that the size and vigor of geothermal surface features are not necessarily representative of the entire system For example, at The Geysers in northern ealifornia, where the surface geothermal features are relatively weak, drilling. revealed the world's largest known reservoir of steam. Electricity generated from The Geysers geothermalf feld, which is fed into the regional power grid, is enough to meet the energy demands of the nearby city of San Francisco Similarly in the mperial Valley of southern California, rare and feeble hot springs belie the presence of many large subterra" nean reservoirs of hot water now party harnessed to produce about 400 megawatts of electrical power A major challenge for ongong exploration is to develop technigues of predrilling surface studies that can help dentify geothermal resources that have nosurace expression whatsoever.

With $20^{\text {th }}$ century technology, drills can penetrate thousands of meters into the Earth Swimers enjoying a hot water pond near Grindavik Iceland. formed by salty waste walerfrom a o oother mal powerplant in backgroundl dumped onto the round This pond called the

Blue Lagoon by" Icelanders is beTieved to have healing powers Photogrâph by Gudmundur $E$ : Sigualdason Nordic Volcanological Insti tute, Reykjavik Ice land Used with per mission. thing

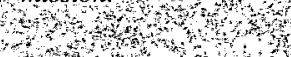
in search of geothermal resources such drilling has resulted in the discovery of geothermal water as hot as $400 \mathrm{C}$, which can provide a resource of high pressure steam to drive turbine generators at the Earth's surface. 


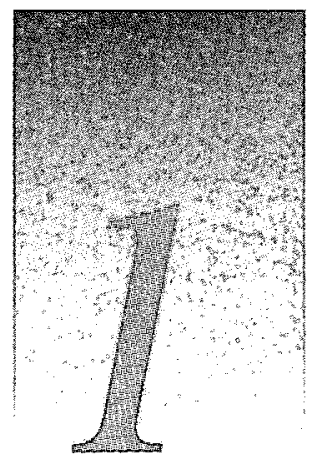

\section{Geothermal Energy as a Natural Resource}

$\mathrm{G}$ eothermal energy is present everywhere beneath the Earth's surface, although the highest temperature, and thus the most desirable, resources are concentrated in regions of active or geologically young volcanoes. Though the resource is thermal energy rather than a physical substance such as gold or coal, many aspects of geothermal energy are analogous to characteristics of mineral and fossil-fuel resources. Geothermal also has some unique, desirable attributes.

\section{GLOBAL DISTRIBUTION}

Measurements made in drill holes, mines, and other excavations demonstrate that temperature increases downward within the Earth. The rate at which the temperature increases (temperature gradient or geothermal gradient) is proportional to the rate at which heat is escaping to the surface through the Earth's crust (heat flow). Thus, zones of higher-than-average heat flow are the most likely places for encountering high temperatures at shallow depth, perhaps

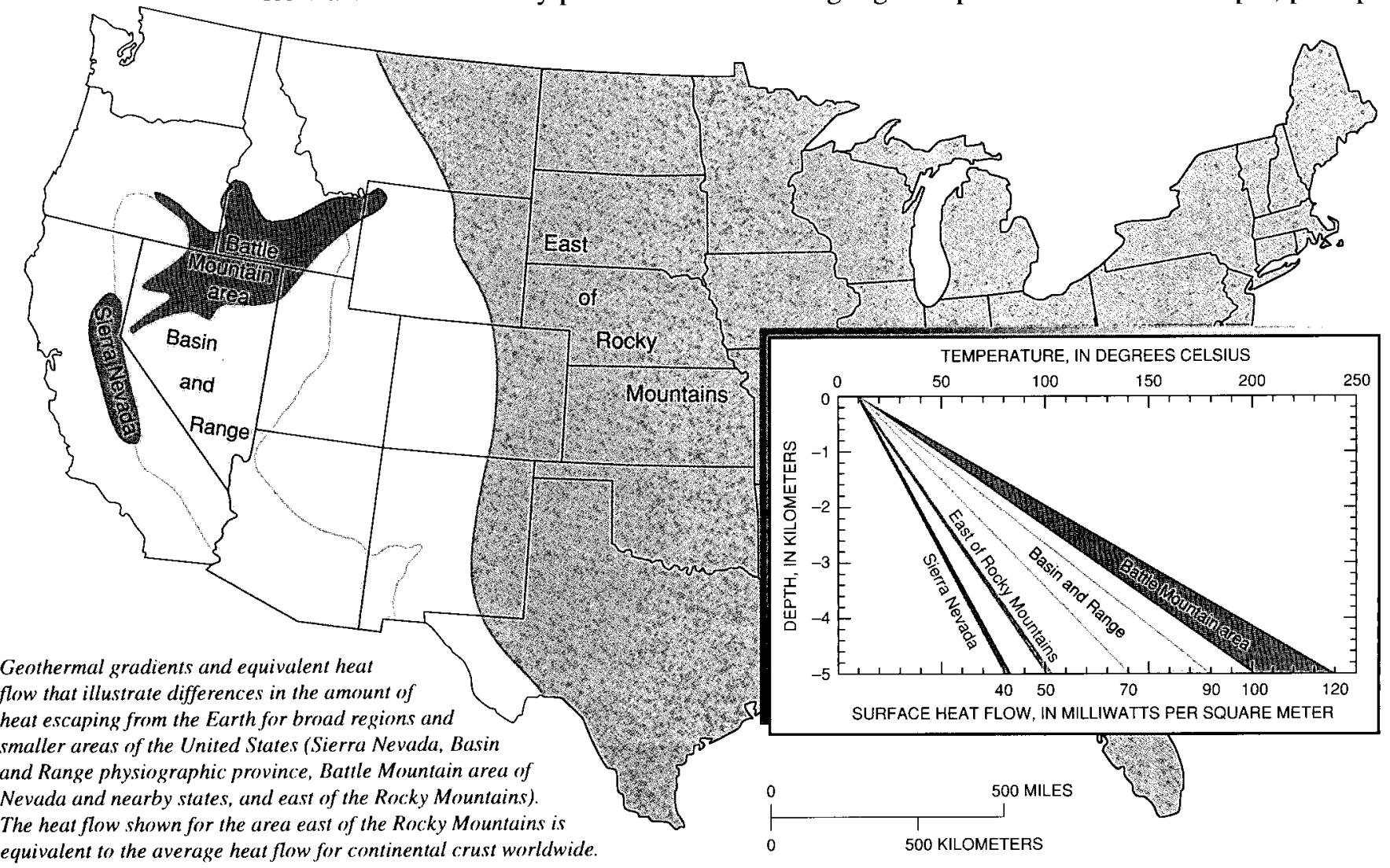




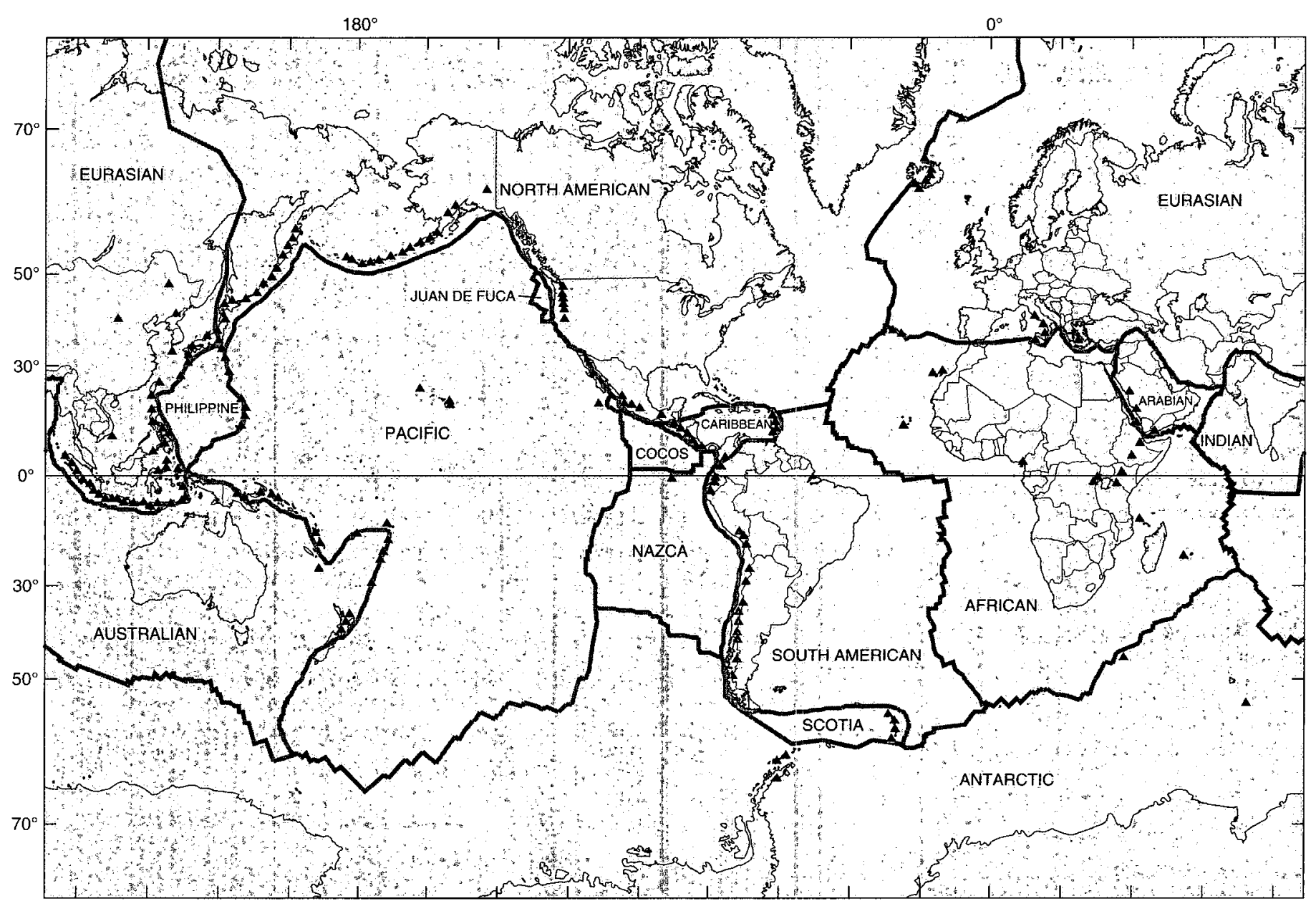

shallow enough to favor exploitation of geothermal energy. Whereas the average rate at which heat escapes through the Earth's crust accounts for a prodigious amount each year, local heat flow varies widely from region to region.

Large quantities of heat that are economically extractable tend to be concentrated in places main lithospheric plates and some of the world's active volcanoes (triangles). where hot or even molten rock (magma) exists at relatively shallow depths in the Earth's outermost layer (the crust). Such "hot" zones generally are near the boundaries of the dozen or so slabs of rigid rock (called plates) that form the Earth's lithosphere, which is composed of the Earth's crust and the uppermost, solid part of the underlying denser, hotter layer (the mantle). According to the now widely accepted theory of plate tectonics, these large, rigid lithospheric plates move relative to one another, at average rates of several centimeters per year, above hotter, mobile mantle material (the asthenosphere). High heat flow also is associated with the Earth's "hot spots" (also called melting anomalies or thermal plumes), whose origins are somehow related to the narrowly-focused upward flow of extremely hot mantle material from very deep within the Earth. Hot spots can occur at plate boundaries (for example, in Iceland) or in plate interiors thousands of kilometers from the nearest boundary (for example, the Hawaiian hot spot in the middle of the Pacific Plate). Regions of stretched and fault-broken rocks (rift valleys) within plates, like those in East Africa and along the Rio Grande River in Colorado and New Mexico, also are favorable target areas for high concentrations of the Earth's heat at relatively shallow depths. 
Agesof selected vol canic eruptions versus volumes of their asso ciated magmabodies for several areas in the United States:

\section{Magma, Volcanoes, and Geothermal Energy}

Geologists realize that bodies of magma in the Earth supper crust are the heat source for most high temperature geothermal resources that have potential for electricity generation The principal evidence for believing this is the common occurrence of young, sometimes active, volcanoes within areas of proven high temperature geothermat resources. Moreover; in many of these volcanic regions, geophysical studies (see seeing Beneath the Earth s Surface discussion) indicate the presence of subsurface low density material that is softer and hotter than adjacent crustal materials this is best interpreted as a magma body sur rounded by denser cooler rigid rocks.

Because of the recognized link between magma bodies and high temperature geothermal resources, geologists of the US. Geological Survey de veloped a method to determine the approximate size and temperature of a hallow magma body from the age and volume of silicic volcanic rocks (that is rocks contaning large amounts of the chemical element silicon) enupted from that body $A$ key point in this method is that for any volume of magma

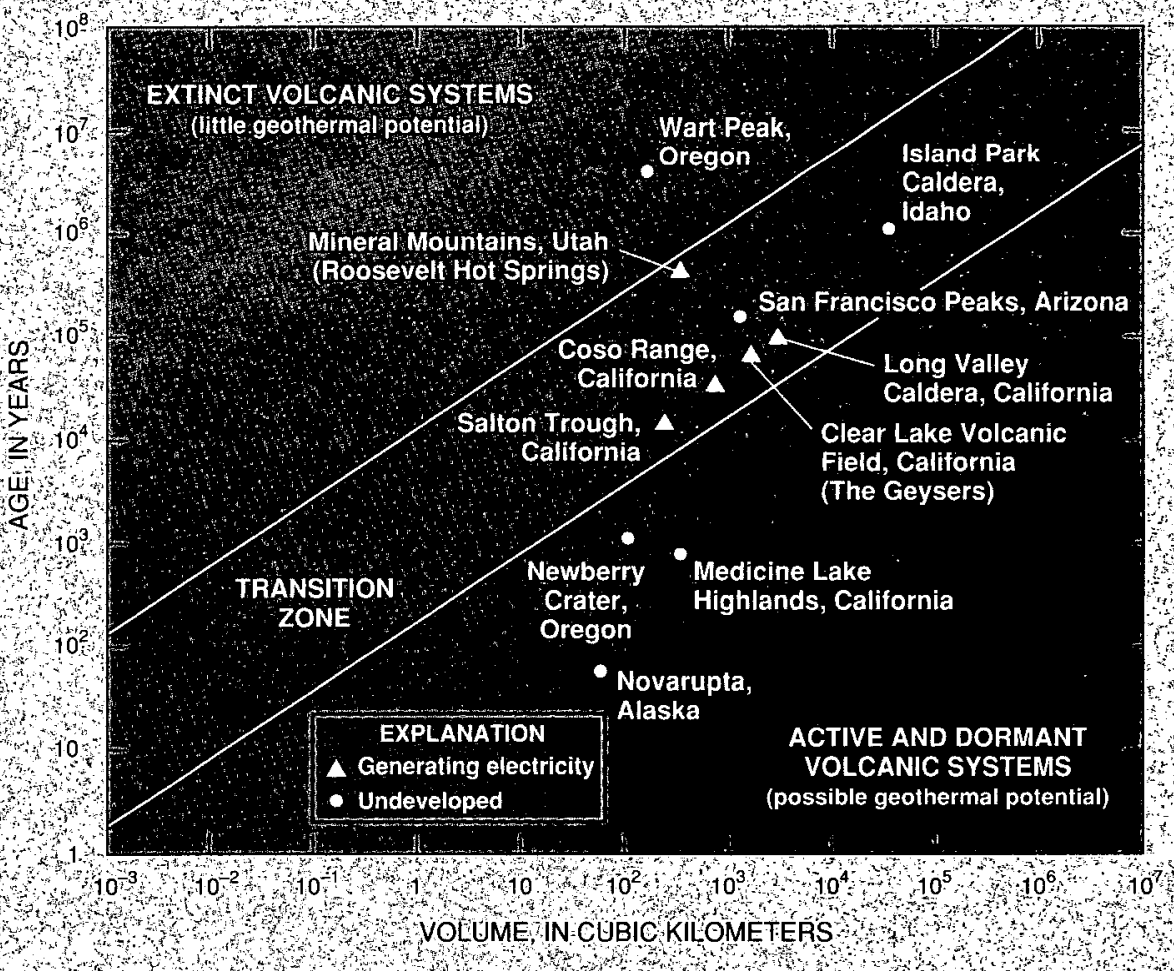

enupted, a volume about ten times that is inferred to remain in the Earth s crust The 1.10 ratio is based on studies of volcanic and subsurface magmatic rock from many 10 cations around the world and is now widely accepted. Another key point of the method is the calculation of about how long it takes for a body of crustal magma to cool Both heat 


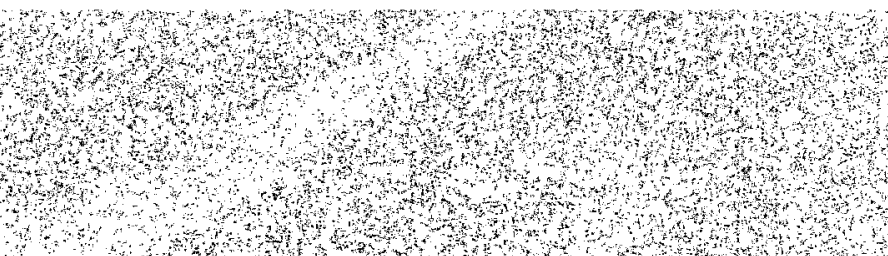

conduction and magmatic convection are considered in various combinations that lead to a classification of volcanic systems, with high geothemal potential, systems with low geother malpotential, and an intervening transition zone within which the geotherimal potential of a system cannot be determined fromavailable information

Because the data needed to calculate geothermal potential include the age and volume of the youngest silicic volcanism for a given volcanic area, early field projects of the US Geological Survey's Geothermal Investigations Program were designed to produce this information for many geologically young volcanie fields of the United States For example the results of field mapping interpreted in the light of the model led to the conclusion that some hundreds of cubic kilometers of magma of at least 650 e are in the crust beneath the Coso volcanic freld (within the Coso Range) in California. Similarly mapping has shown that 15 cubic kilometers of magma was erupted in 1912 at Novarupta (Katmai Groupof Volcanoes) to produce a volcanic deposith that partly fills the Valley of Ten Thousand Smokes in Alaska Accordingly the model suggests that the present magma body beneath Novarupta is at least $650^{\circ} \mathrm{C}$ and around a hundred cubic kilometers in yolume on the bas of other recently gathered data, the model suggests less geothermal potential for the more voluminous magma volcano system of the San Francisco Peaks in Arizona, because the most recent silicic enuption there was tens of thousands of years ago A smaller volume and even older system, such as Wart Peak, Oregon, is calculated to contain little or no geothermal potential The plot showing age of the most recent silicic enuption versus volume of the associated magma body for several magma volcano systems demonstrates how these characteristies are related to geothermal potential The large amounts of geothermal energy that reside in national parks suchas Katmai and Yéllowstone are exeluded from exploration and de velopment However, the age volume model ndicates that other areas such as Mineral Mountains in Utah, as well as Coso volcanic field and Medicine Lake Highlands in Californa have vary ng high degrees of geothermal potential Recent commercial surface exploration and follow up drilling there have, in fact proved the presence of ahightem perature geothermal resource in eachof these three areas

In addition to a hot water steam (hydrothermal) component by far the majority of the thermal energy associated with a magma volcano system resides in the magmabody itself and the hot rockaround it Using current technology, only the hydrothermal component can be exploited, meanwhile, studies are in progress to demonstrate the feasibility of possible future exploitation of the nonhy drothermal components of geothermal energy.

\section{Because of the} recognized link between magma bodies and

high-tempera-

ture geothermal

resources,

geologists of

the U:S, Geo-

logical Survey

developed a

method to

determine the

approximate

size and tem-

perature of a

shallow magma

body

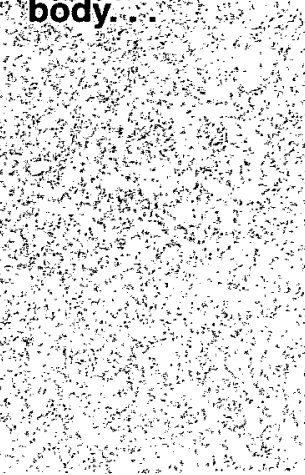


Zones of high heat flow near plate boundaries are also where most volcanic eruptions and earthquakes occur. The magma that feeds volcanoes originates in the mantle, and considerable heat accompanies the rising magma as it intrudes into volcanoes. Much of this intruding magma remains in the crust, beneath volcanoes, and constitutes an intense, high-temperature geothermal heat source for periods of thousands to millions of years, depending on the depth, volume, and frequency of intrusion. In addition, frequent earthquakes - produced as the tectonic plates grind against each other - fracture rocks, thus allowing water to circulate at depth and to transport heat toward the Earth's surface. Together, the rise of magma from the mantle and the circulation of hot water (hydrothermal convection) maintain the high heat flow that is prevalent along plate boundaries.

Accordingly, the plate-boundary zones and hot spot regions are prime target areas for the discovery and development of high-temperature hydrothermal-convection systems capable of producing steam that can drive turbines to generate electricity. Even though such zones constitute less than 10 percent of the Earth's surface, their potential to affect the world energy picture and related political and socioeconomic consequences is substantial, mainly because these zones include many developing nations. An excellent example is the boundary zone rimming the Pacific Plate-called the "Ring of Fire" because of its abundance of active volcanoesthat contains many high-temperature hydrothermal-convection systems. For the developing countries within this zone, the occurrence of an indigenous energy source, such as geothermal, could substantially bolster their national economies by reducing or eliminating the need to import petroleum. The Philippines, Indonesia, and several countries in Central America already benefit greatly from geothermally generated electricity; additional projects are underway and planned. Of course, the use of geothermal energy already contributes to the economies of industrialized nations along the circum-Pacific Ring of Fire, such as the United States, Japan, New Zealand, and Mexico; Canada is expected to have its first geothermally powered electrical plant on line soon.

\section{COMPARISON WITH OTHER NATURAL RESOURCES}

Geothermal resources are similar to many mineral and energy resources. A mineral deposit is generally evaluated in terms of the quality or purity (grade) of the ore and the amount of this ore (size or tonnage) that can be mined profitably. Such grade-and-size criteria also can be applied to the evaluation of geothermal energy potential. Grade would be roughly analogous to temperature, and size would correspond to the volume of heat-containing material that can be tapped. For mineral and geothermal deposits alike, concentrations of the natural resource should be significantly higher than average (the background level) for the Earth's crust and must be at depths accessible by present-day extraction technologies before commercial development is feasible.

However, geothermal resources differ in important ways from many other natural resources. For example, the exploitation of metallic minerals generally involves digging, crushing, and processing huge amounts of rock to recover a relatively small amount of a particular element. In contrast, geothermal energy is tapped by means of a liquid carrier-generally the water in 
the pores and fractures of rocks - that either naturally reaches the surface at hot springs, or can readily be brought to the surface through drilled wells. The extraction of geothermal energy is accomplished without the large-scale, landscape-scarring movement of rock involved in mining operations, such as mine shafts and tunnels, open pits, and waste heaps.

Geothermal energy has another important advantage. It is usable over a very wide spectrum of temperature and volume, whereas the benefits of other natural resources can be reaped only if a deposit exceeds some minimum size and (or) grade for profitable exploitation or efficiency of operation. For example, at the low end of the spectrum, geothermal energy can help heat and cool a single residence. To do so requires only the burial of piping a few meters underground, where the temperature fluctuates little with the changing seasons. Then, by circulating water or some other fluid through this piping using a standard heat pump, thermal energy is extracted from the ground during the coldest times of the year and deposited in the ground during the hottest times. Together, the heat pump and the Earth's thermal energy form a small, effective, and commercially viable heating and cooling system. This type of system is already in use at more than 100,000 buildings in the United States.

Toward the high end of the spectrum, a single large-volume, high-temperature deposit of geothermal energy can be harnessed to generate electricity sufficient to serve a city of 1 million people or more. For example, at The Geysers (which is the commonly used name for the Geysers geothermal area) in northern California, fractures in rocks beneath a large area are filled with steam of about $240^{\circ} \mathrm{C}$ at depths that can easily be reached using present-day drilling technology. This steam is produced through wells, piped directly to conventional turbine generators, and used to generate electricity. With an installed capacity of more than 1,500 megawatts electric, The Geysers is presently the largest group of geothermally powered electrical plants in the world. At current rates of per capita consumption in the United States, 1 megawatt is sufficient to supply a community with a population of 1,000 .

Between these relatively extreme examples are geothermal resources that encompass a broad spectrum of grade (temperature) and tonnage (volume). The challenge, for governmental agencies and the private sector alike, is to assess the amount and distribution of these resources, to work toward new and inventive ways to use this form of energy, and to incorporate geothermal into an appropriate energy mix for the Nation and the world.

Toward the high end of the spectrum, a single large-volume, high-temperature deposit of geothermal energy can be harnessed to generate electricity sufficient to serve a city of 1 million people or more. 


\section{Geothermal Energy and the Ring of Fire}

The volcanically active and earthquake prone regon rimming the Pacif as the Ring of Fre This region could also be called the Ring of Geothermal Energy because it contains many high temperature geothermál systems associated with active voleas noes Hundreds of volcanoes girdle the Pacific Basin from the Aleutian Range of Alaskas through the Kamchatka Peninsula, Japan the Philippines Indonesia New Zealand the Andes Central America, Mexico, and the Cascade Range of the Pacific Northwest and Canada. Projects to harness geothermal energy are either underway or on line in all of these areas In some developing countries such as in Central America the use of geothermal energy to provide electricity could also provide social and economic benefits.

Many active volcanoes form a long chain that parallels the Pacific Coastal Plain from Mexico across Guatemala, Honduras, El Salvador, Nicaragua, Costa Rica, and Panama. Abundant geothermal features hot springs, fumaroles and boiling nud pots, are associ ated with these volcanoes Some Central American countries have hydroelectric resources

Part of the circum Pacific Ring of Fire is defined by a chain of active volcanos (solid triangles) pars alleling the Pacific Hoastof Central America Geothermal projects are either on line or in progress at

Zunil Amatitlan and Tecuamburrol Guatemala), A huachapan and Berlin (El Salva otodor) Platanares (Honduras) Momotombo (Nicara gua) ond Miravalles (Costa Ricá) There are other excellent geothermal prospects in Central Americal

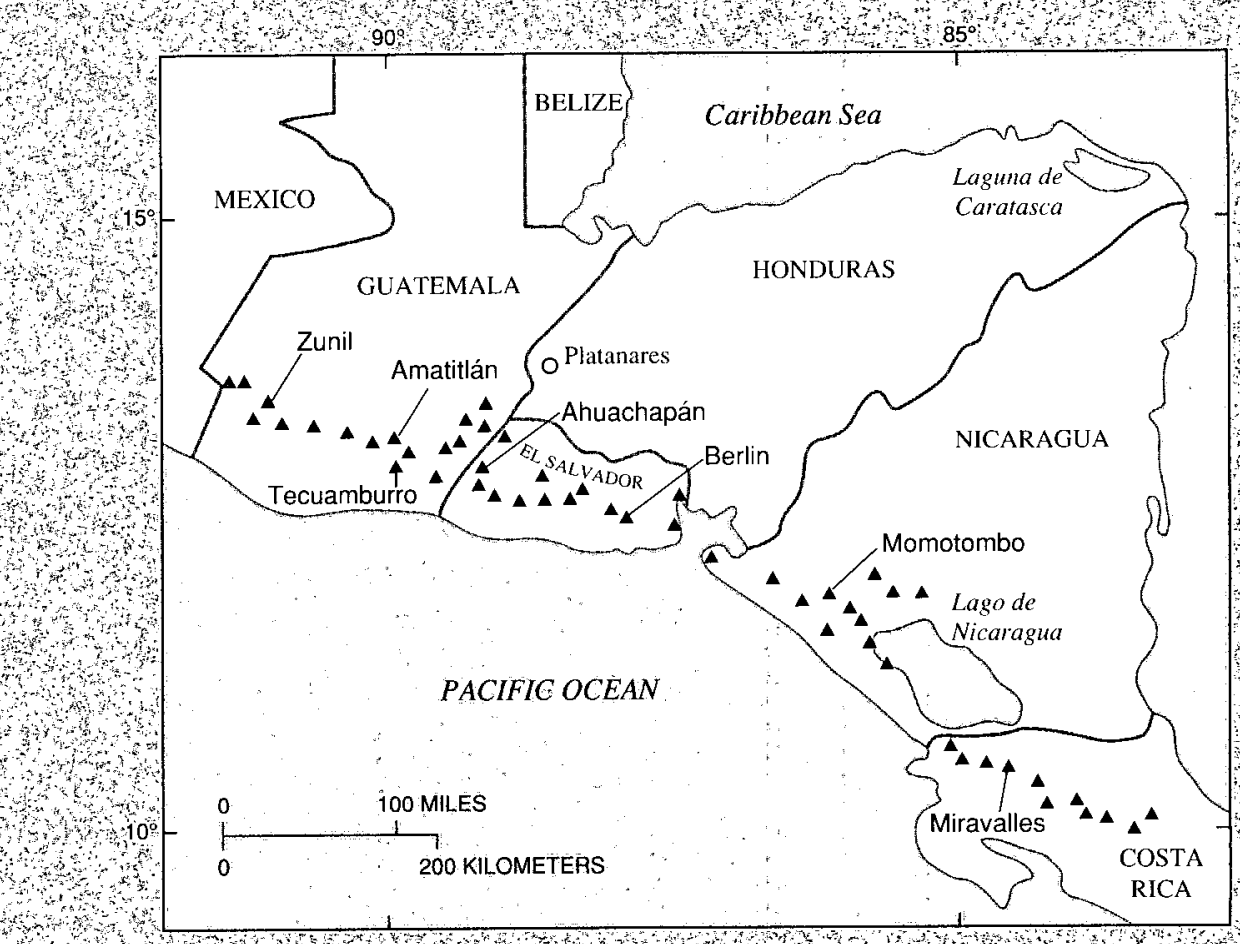

that help satisfy national energy demands stil, all nust mport considerable amounts of petroleum to fuel their economies and to supply the energy demands of rapidly growing populations. Geothemal energy is viable and developing altenative energy source to petroleum in these regions El Salvador and Nicaragua began generating electricity with geothermal energy in the mid 1970 , and, at present, geothermal energy providés about a 


\section{The volcanically active and earthquake prone region rimming the \\ Pacific ocean is known as the Ring of Fire.this region could also be called the Ring of Geo- thermal Energy, because it contains many high- temperature geothermal systems associated with active volcanoes.}

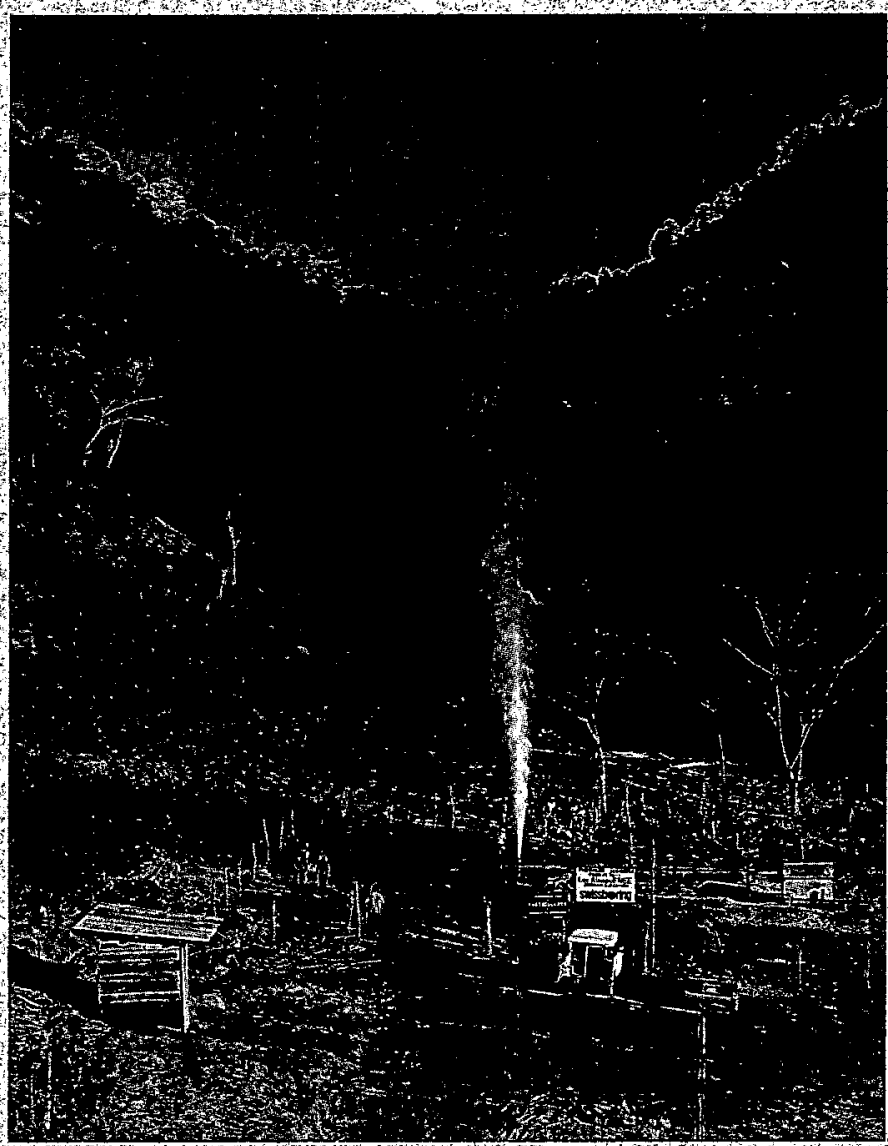

third of the electrical powerneeds of El Salvador With a more favorable political and economic climate these two countries probably could satisfy much more of their electrical demand from geothermal resources

In Costa Rica, about 55 megawatts of generating capacity came on line at Miravalles in 1994. This capacity is scheduled to be doubled by 1995 , thus providing about 10 percent of that nation's electricity Other barely explored geothermal resource areas are present in Costa Rica.

Guatemala is close to producing its first geothemal electricity, at Zunil, An initial 15 megawattelectric capacity is scheduled to be doubled by the end of the century Geothermal prospects are being evaluated at A matitlán and Tecuamburo. With an abundant hy droelectric option, the Guatemalan Government could blend hydropower and geothermal on way that reducesandminimizes the proportion of national demand now satisfied by imported petroleum and other conventional energy sources.

Honduras has little Pacific $O$ cean front and therefore occupies little of the Ring of Fire. Nonetheless, several geothermal prospects are identified in Hondura, and a fewof these are hot enough to produce electricity Holes drilled duning the mid 1980 s a platanares revealed a hydrotherma 1 s ytem at $16 \mathrm{C}^{\circ} \mathrm{C}$ a temperature sufficient to generate electricity Additional drilling at this and other locations is needed to better characterize the geothermal resources of that nation 


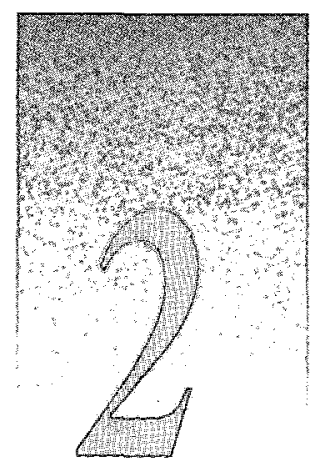

\section{Geothermal Environments and Energy Potential}

$\mathrm{T}$ hermal energy is contained in a variety of geothermal environments, and these commonly are classified by temperature and amount of fluid — water and (or) steam-available for carrying the thermal energy to the Earth's surface. The magma environment is the highest temperature and a relatively water-poor part of this classification. Magmas range in temperature from about 650 to $1,300^{\circ} \mathrm{C}\left(1,200\right.$ to $\left.2,400^{\circ} \mathrm{F}\right)$, depending on chemical composition. For comparison, common steel melts at about $1,500^{\circ} \mathrm{C}$. Even the most water-rich magmas contain no more than a few weight percent of water, an amount insufficient and unavailable for geothermal use. These bodies of magma in the crust are termed "dry" and are the ultimate sources of heat for other geothermal environments.

With decreasing temperature, the magma environment passes into what is called the hotdry-rock environment. This is characterized by hot, solid rock that contains little or no available water because it has few pore spaces or fractures to store (the open space within a rock is called porosity) and transmit water (the capacity of a porous rock to transmit fluid is called its permeability). With increasing water, the hot-dry-rock environment gives way to a broad cat-

Different types of geothermal environments in the Earth's upper crust. Generally, temperature increases with depth, but the depth line is dashed to indicate that the rate of temperature increase varies within the crust. "Available" refers to water and steam in rocks that can be tapped by a well and produced at the Earth's surface. High-and moderatetemperature rocks with considerable available water and (or) steam are the only geothermal environments that can currently be developed to generate electricity.
"AVAILABLE" WATER OR STEAM

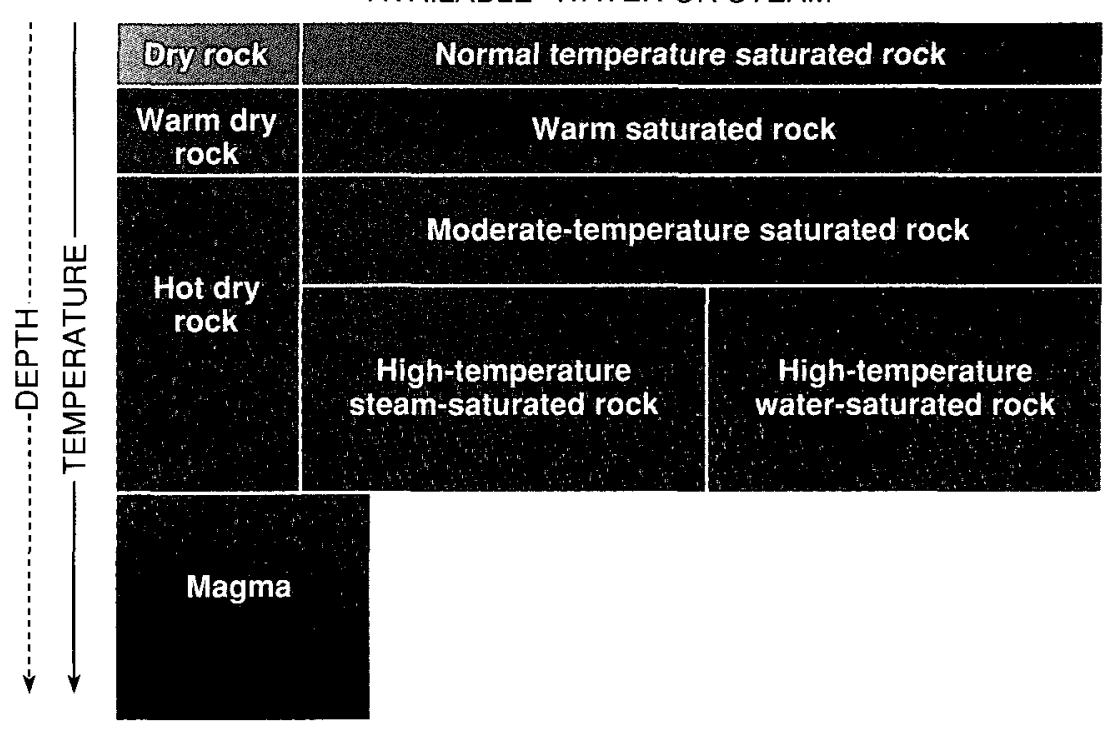


egory of fluid-saturated rocks with variable porosity, permeability, and temperature. Within this category are relatively high temperature rock, saturated either with steam or liquid water or a mixture of both, and rocks saturated only with water at increasingly lower temperatures. Geothermal environments through which available water circulates freely are called hydrothermal-convection, or simply, hydrothermal systems.

In nature, the various geothermal-energy environments commonly occur in close proximity, separated by boundaries that can be either relatively abrupt or gradual. For example, a body of magma in the Earth's crust is enveloped by hot, solid rock whose temperature decreases outward from the magma. With or without an associated body of magma, hot dry rock and fluid-saturated, high-temperature rock environments generally coexist within a well-defined, anomalously hot part of the Earth's crust, the distinction between them being in the amount of available fluid and permeability. In contrast, moderate- to normal-temperature hydrothermal systems may occur in isolation, if circulating water is heated solely by flowing through crustal rocks, without input from an adjacent, high-temperature magmatic heat source.

Determining whether or not heat can be extracted from a particular geothermal environment is critically dependent on depth. The pertinent question is whether the geothermal target is within economically drillable depths, roughly 4 kilometers or less with current technology. Each of the geothermal environments can occur over a range of depths, depending upon the geologic characteristics of a given geographic site. For example, most magma bodies in the Earth's crust are estimated to be about 5 kilometers deep, or slightly deeper; yet some bodies of molten rock pond in craters at the Earth's surface during volcanic eruptions and cool and solidify there under their own thin but growing crust. Similarly, exploitable geothermal energy in hydrothermal systems around $250^{\circ} \mathrm{C}$ may be discovered at depths from one to several kilometers, depending upon the local geothermal gradient and the vigor of upward flow of hot fluids. For optimum exploitation, a major challenge is to locate geothermal environments of maximum temperature at minimum depth.

\section{HYDROTHERMAL SYSTEMS}

Geothermal potential also is highly dependent on rock porosity and permeability. For a given reservoir temperature, the greater the porosity and permeability of a hydrothermal system, the greater its production of available water and thus energy yield. In today's market, with current and foreseeable technologies, the hydrothermal environment is the only commercially exploitable form of geothermal energy. New technologies must be developed to extract the potential thermal energy associated with any of the dry geothermal environments.

\section{Electrical-Grade Systems: Power Generation}

As the name implies, an electrical-grade hydrothermal system is one that can generate electricity by means of driving a turbine with geothermal fluids. At present, only the high- and moderate-temperature hydrothermal systems can be so used. The temperature that separates electrical-grade from cooler hydrothermal systems varies, but it falls within the 100 to $150^{\circ} \mathrm{C}$ 
(left) Diagram showing how electricity is generated from a hot-water hydrothermal system.

The part of the hydrothermal water that flashes to steam is separated and used to drive turbine generator

Wastewater from separator and condenser is injected back into the subsurface to help extend the useful life of the hydrothermal system.

(right) Diagram showing how electricity is generated from a vapor-dominated hydrothermal system. Steam is used directly from wells to drive a turbine generator. Wastewater from the condenser is injected back into the subsurface to help extend the useful life of the hydrothermal system.
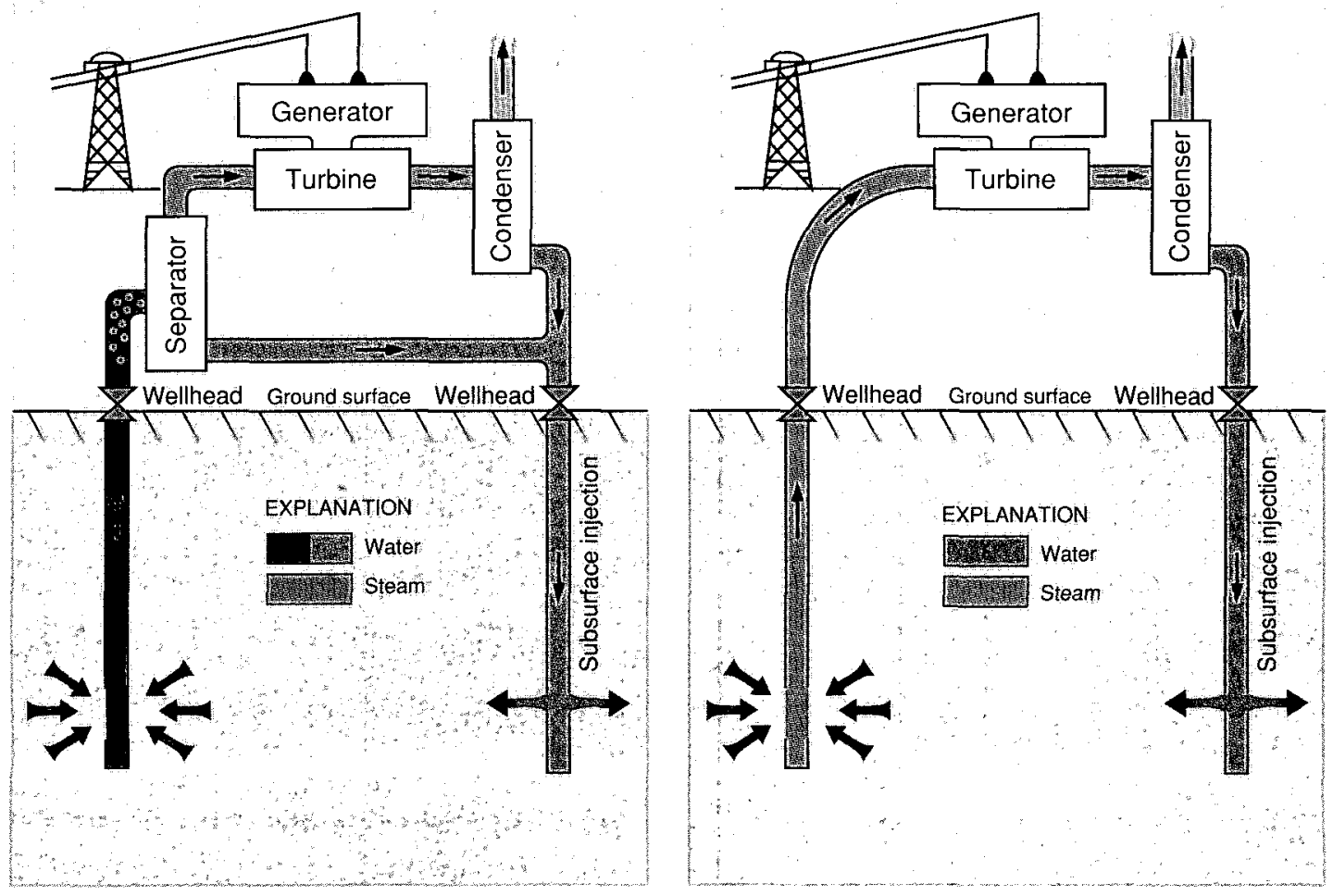

range. There are three types of electrical-grade hydrothermal systems: hot-water, vapor-dominated, and moderate-temperature water (binary) systems.

Hot-water hydrothermal systems of about $200^{\circ} \mathrm{C}$ or more are capable of producing steam at pressures sufficient to drive turbine generators. These systems are in porous and permeable rock saturated with water, which partly boils to steam when it rises up production wells. This steam is routed to a turbine generator to produce electricity. A prime example of a hot-water system is the geothermal field at Coso in south-central California.

Less commonly, rocks of a high-temperature hydrothermal system are partially saturated with steam, rather than liquid water; such systems are called vapor-dominated. The origin of these systems requires a combination of a potent heat source and a restricted source of water recharge. In these situations, only steam is produced through the wells, and this steam can be routed directly into turbine generators. Because the vapor-dominated systems do not require the separation of steam from water, the energy they contain is relatively simple and efficient to harness; accordingly, such systems are most desirable for electrical power production. Like most highly sought after commodities, vapor-dominated systems are rare compared with their valuable but less-simple-to-develop counterparts, the hot-water systems. The largest vapordominated system developed in the world is at The Geysers in northern California.

Moderate-temperature hydrothermal systems are incapable of producing steam at high enough pressure to directly drive a turbine generator; they are hot enough to produce a high-pressure 


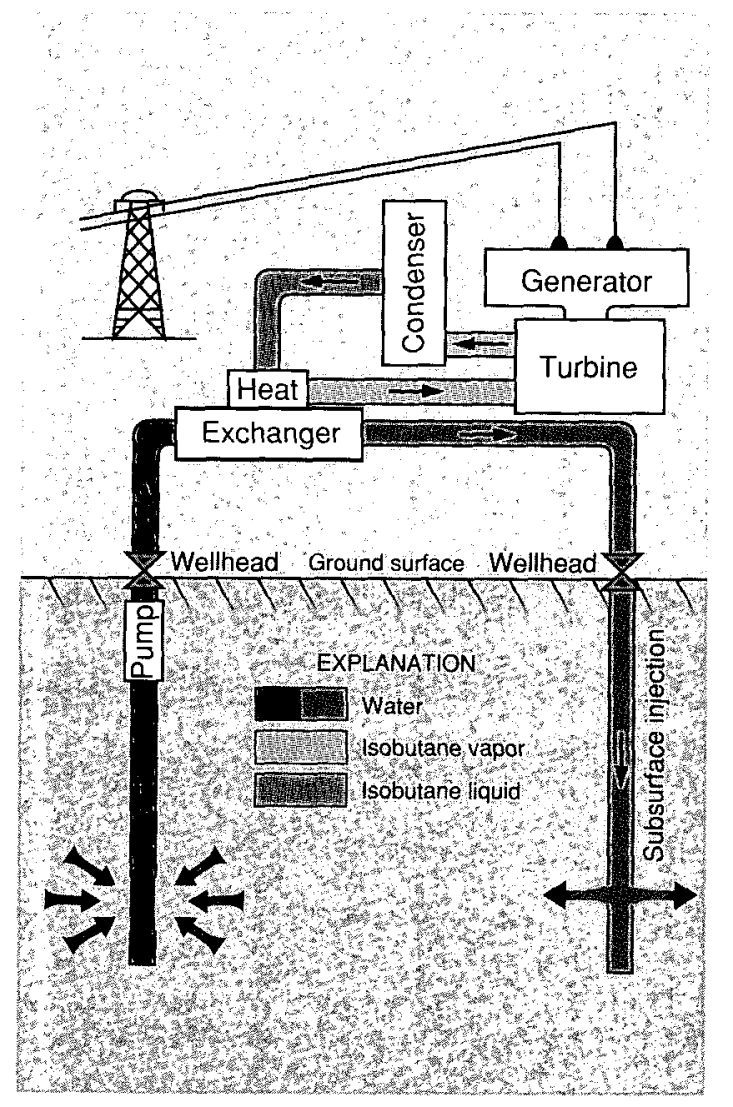

Diagram showing how electricity is generated from a moderate-temperature hydrothermal system. The geothermal water is used to boil a second fluid (isobutane in this example) whose vapor then drives a turbine generator. The wastewater is injected back into the subsurface to help extend the useful life of the hydrothermal system.

\section{Because the vapor-dominated systems do not require the separation of steam from water, the energy they contain is relatively simple and efficient to harness; accordingly, such systems are most desirable for elec- trical power production.}

vapor through heat transfer to a second "working" fluid, which in turn drives a turbine generator. The power-generation technique that transfers the geothermal heat to another fluid (for example, isobutane), whose boiling temperature is lower than that of water, is called a binarycycle, or simply, a binary system. Binary systems that produce geothermal electricity were recently installed near Mammoth Lakes, east of the Sierra Nevada in central California. By taking advantage of the more widespread distribution of moderate-temperature geothermal water, binary systems can add significantly to the overall contribution to geothermally generated electricity.

As of 1990, geothermally powered generating capacity was about 2,800 megawatts electric in the United States and 5,800 megawatts electric worldwide. The annual rate of growth in power production from hydrothermal systems averaged about 6 percent through the 1980's. 


\section{Tapping the Geothermal Potential of the Great Basin}

Geothermal systems whose main fluid is water (in contrast to steam)-called waterdominated hydrothermal systems - are the most common type used by the geothermal electrical industry. One of the most recently harnessed of these systems is at the Coso geothermal area in south-central California. This area lies within the Coso Range, which is located along the southwestern margin of the Great Basin, a physiographic section that includes the eastern part of California, most of Nevada, and the western part of Utah The Great Basin is part of the Basin and Range physiographic province. The Great Basin has high geothermal potential because geologically recent fracturing of rocks in this region enhances the circulation of geothermal fluids, and because of the many young volcanoes along its margins whose underlying magma bodies serve as potent heat sources for geothermal fluids.

The Coso geothermal area has long been recognized to hold significant geothermal potential, because the area contains patches of hot, steaming ground as well as scores of volcanic cones and domes whose nearly uneroded shapes indicate geologic youth. In the mid 1970's, a team of Federal Government and university scientists began a multidisciplinary assessment of the Coso geothermal area in an attempt to quantify its resource potential. The project included a variety of geologic, geophysical, geochemical, and hydrologic studies, whose combined results suggested a resource equivalent to 650 megawatts of electrical generating capacity for a minimum of 30 years.

Virtually all of the Coso geothermal area is on Federal land. Much is within the bounds of the China Lake Naval Weapons Center. The very first well drilled by industry was a commercial success, and subsequent wells have resulted in an unusually high success ratio. By 1990,240 megawatts of electrical-generating capacity were on line and contributing power to the Naval Weapons Center and the southern California power network. On average, this is enough electricity to supply the needs of a United States city with a population of 240,000 The Coso powerplants are providing the China Lake

Map of Western United Statesroughly heart shaped area in center of map is the Great Basin Dot in upper right part of Great Bäsin is Roosevelt Hot Springs, dot in lower left is Coso aval Weapons Center with substantial annual savings. In addition, the geothermal energy produced displaces the need for comparable generating capacity by other and perhaps less environmentally benign means.

About 550 kilometers east northeast of Coso geothermal area, along the eastern margin of the Great Basin, Roosevelt Hot Springs and Cove Fort geothermal area near Coye Fort, $\mathrm{tah}$, mark another concentration of fault-broken rocks and geologically youthful volcanoes, with their associated geothermal potential Geothermally powered electrical generation capacity there at present is about 35 megawatts and there are plans to develop about 200 megawatts more. 


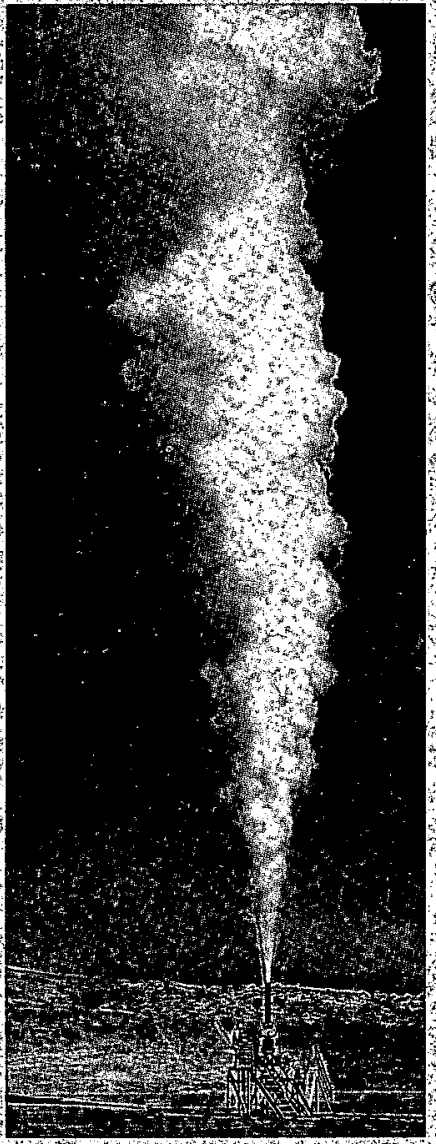

First geothermal well drilled at Coso geothermal area, south-central Califormia by privates industry It, to gether with a few other wells has been developed to feed steam into the initial powerplant.

\section{Virtually noneroded}

lava domes and flows are visual evidence of the geologic youth of the coso geothermal. area $A$ magma body in the crust beneath this area is the likely heat source for the Coso hydrothermalconvection system
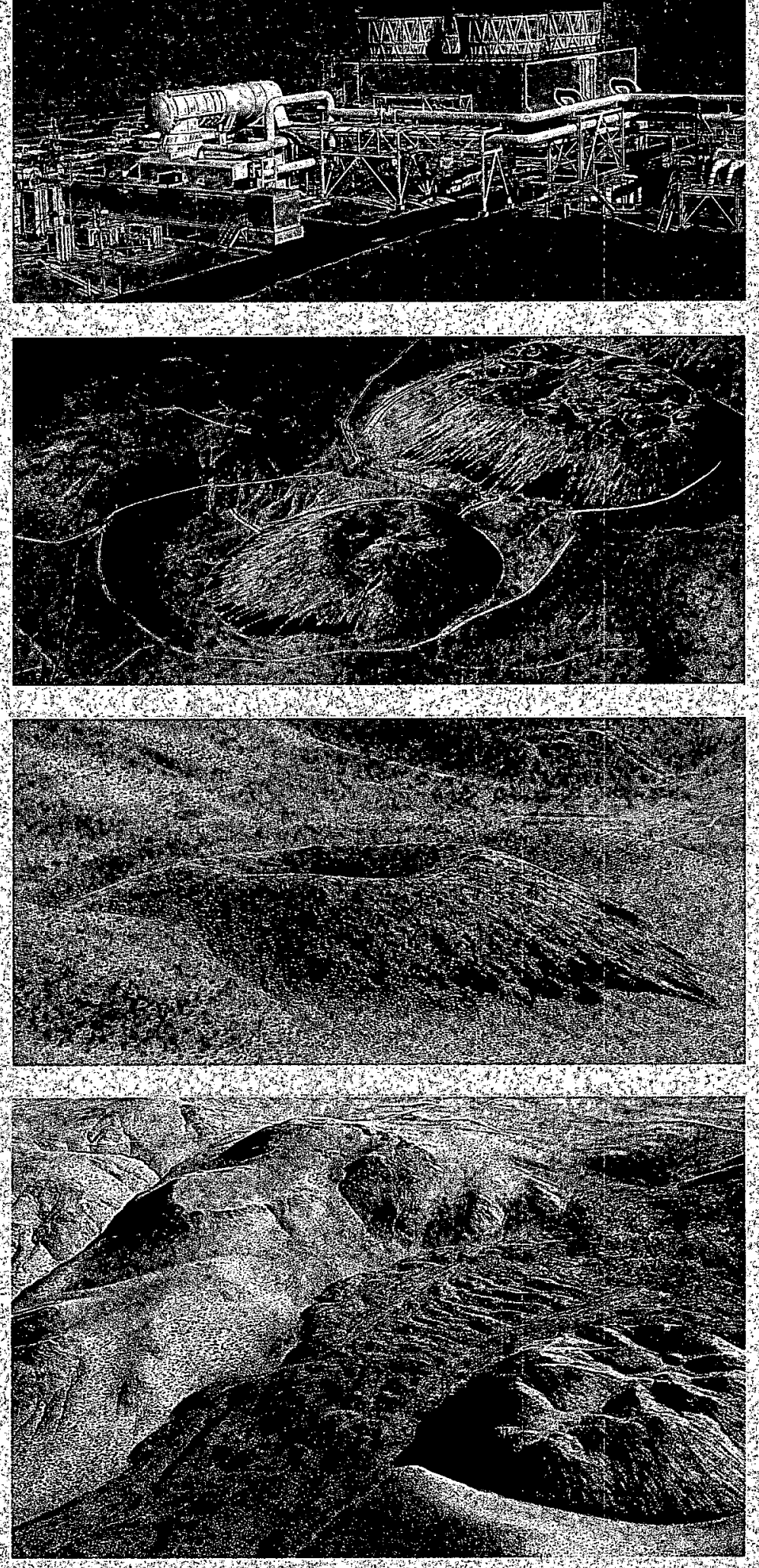

Aerial view of a basalt tava flow emplaced around the base of $a$ lumpy topped rhyolite do me 


\section{The Geysers, California-World's Largest Producer of Geothermal Electricity}

it was not

until 1924 that

the first

production

wells were

drilled and a

few kilowatts

of electrical

power were

generated for

use at a local

resort During

the 1950's,

wells were

drilled as deep

as 300 meters;

and the main

steam reser-

voir was thús

discovered.few

people had

any idea that

the steam

reservoir

coùld be

developed to

the extent that

it was by the

1990 's.

The Geysers, a vapor dominated hydrothermal system in northern California; has grown into the world's largest geothermal electrical development. The production level in 1992 was 1300 megawatts, enough to satisfy anited States city of about 13 million people. By 1992 , The Geysers had produced almost 160 billion kilowatt hours of electric ity equivalent in energy to 200 million barrels of oil

It took decades for people to recognize the huge energy potential of The Geysers. The surface geothermal features, weak fumaroles and warm springs, were known to settlers in the region by the mid 1800 's but it was not until 1924 that the first production wells were drilled and a few kilowatts of electrical power were generated for use at a local resort During the 1950 , wells were drilled as deep as 300 meters, and the main steam reservoir was thus discovered At that time, however, few people had any dea that the steam reservoir could be developed to the extent that twas by the 1990 ' $\mathrm{According}$, development proceeded cautiously, from the first powerplant of 12 megawatts electrie in 1960 to a total installed capacity of 82 megawatts by 1970 Major growth during the $1970 \mathrm{~s}$ brought the electrical capacity to 943 megawatts by 1980 and even faster growth during the 1980 s pushed capacity to over 2,000 megawatts by the end of the decade. Twenty -six individual powerplants had been constructed by 1990 anging from 12 negawatts to 19 megawatts. More than 600 wells had been drilled by 1994 , some as deep as 3.2 kilometers and capital investment by then was over $\$ 4$ billion

Located in nountainous, sparsely inhabited terrain approximately 120 kilometers north of San Francisco the production area the Geysers geothermall field covers nearly 80 square kilometers and is surrounded by an area 10 times as large in which the amount of heat being conducted to the Earth's surface is anomalously high The Geysers is located just south west of the Clear Lake volcanic field, whose most recent yolcanic eruptions occurred only a few thousand years ago. Accordingly, it is likely that The Geysers geothermal field is sustained by hot or molten rock at depths of 5 to 10 kilometers. Despite its name, there never were true geysers (periodically spouting hot springs) in the area, the surface features before drilling were restricted to weak steam vents, warm ground, and mudpots, whose unimpressive character belied the huge resource below. Indeed The Geysers is an unusual geothermal field in that its wells produce nearly pure steam, with no accompanying water

Because of ts large size and resultant importance to the electricity supply in Californa, The Geysers has been studied intensively In the early 970 , data from The Geysers were crucial to U S Geological Survey scientists in devising a now widely accepted general model for vapordominated (dry steam) hydrothermal systems. The Geysers has been a natural laboratory for geothermal exploration and reservoir engineening 


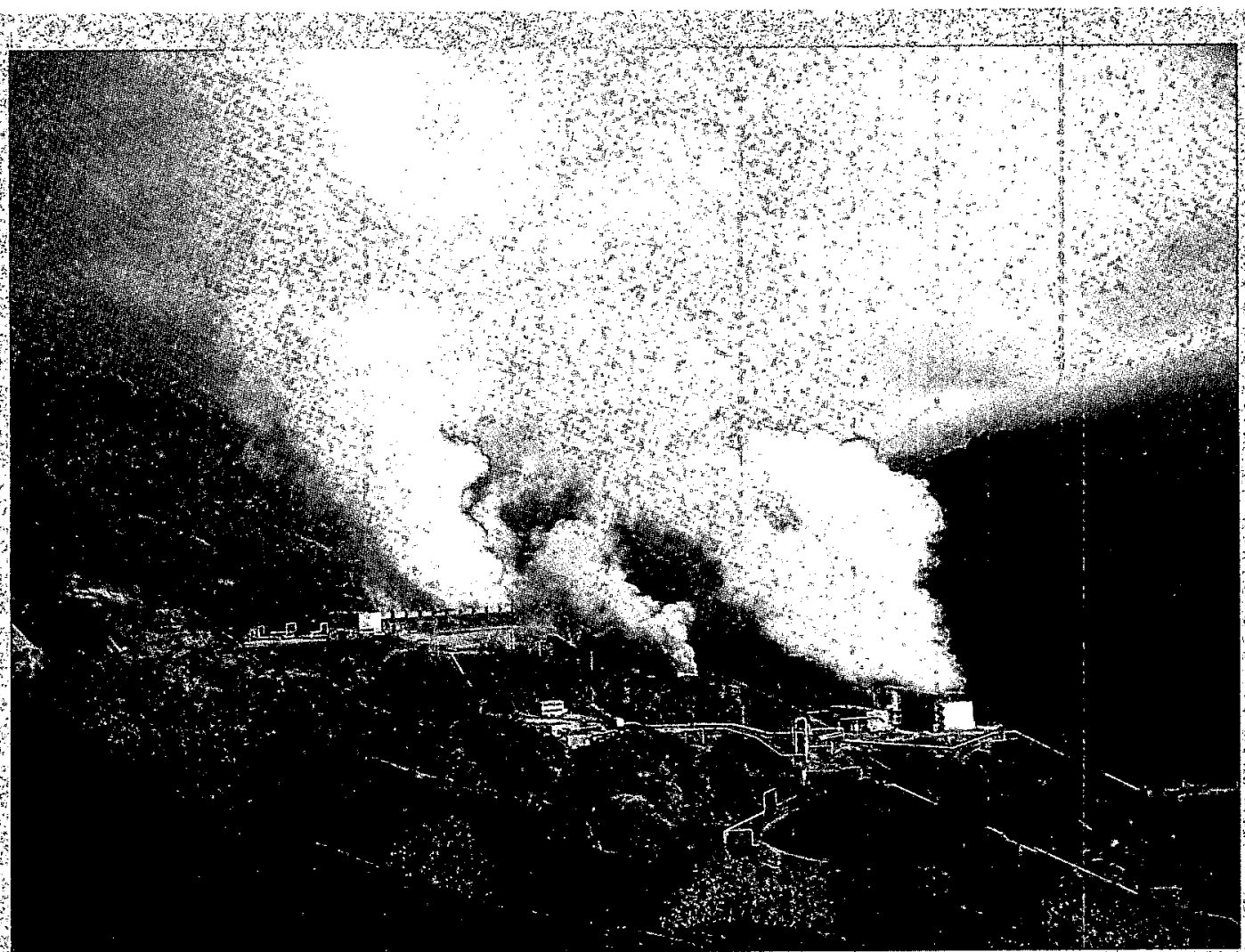

studies, and in the application of both traditional geophysical methods from the oil industry and innovative geochemical methods particular to geothermal fields And finally, The Geysers has led in the development of abatement techniques that reduce emissions of hydrogen sulfide gas commonly contaned in geothermal fluids to nearly zero

As a result of the rapid development at The Geysers during the 1980 , shere has ben a recent decline in the rate of steam production (and electrical generation) due to loss of pressure in production wells Steam prodúction peaked in 1988 , and has declined continuously since then. Current studies ndicate that a 10 wer, but more sustainable rate of steam production will be reached over the next decade, especially if additional water sources can be used to increase the quantity of liquid water injected tinto the reservoir Nonetheless, The Geysers remains the worlds premier geothermal field, and it continues to provide over 1000 megawatts of electrical power to the people of California with little environmental impact The decline in reservour pressure has prompted the individuâl steamproducing companes each of which previously held propretary iformat on to share production data and collaborate witheach other and with scientists of the US Geological Survey and the Bepartment of Energy's National Laboratories to find ways to extend the useful life of the entire geothermal system Most of the geothermal energy of this system remains unmined stored nocks that form the hydrothermal reservoir The team of private and government researchers is challenged to find ways to enhance the heat recovery from this reservoir and to ncrease the efficiency with which the steam produced at the surface can be converted to electricity

The Geysers near the cityof Santa Rosa in northern California is the worlds largest electricity generating geothermal develop: ment Most of the wells are about 3,000 meters deep or some what less and pro duce nearly pure steam Pipes carry stean to turbine gen erators and associated condensers $V a$ por plumes from con densers are visible here Generators range from about 10 10100 megawat rat ings, many are about 50 megawatts Sev eral steam wells feed into a single genera tor. After geothermal development the land is available for other purposes such as srazing Photograph by Julie Bonnelly Nolan 


\section{Electricity from Moderate-Temperature Hydrothermal Systems}

\section{Heat exchang \\ ers transfer \\ thermal energy}

from $170 \mathrm{C}$

water to the

isobutane,

which vapor-

izes and drives

the turbine

generators.

Binary cycle gother malpowerplants near Mammoth Lakes California Mammoth Môntain in back ground on right Pho. tograph by Edward Evans Geothermal Resources Council Davis Califormia Used with permission

Many hydrothermal systems contain water too cool to directly power steam driven turbine generators yet hot enough to boil anotherfluid whose vapor can drive the turbine. This method of power production called abinarys sysem utilizes the combined properties of geothermal water and a second so called working fluid" in the energy conversion cycle. $A$ geothermal development employing a binary system with sobutane as the working fluid is currently in operation near Mammoth Lakes, east of the Sierra Nevada in central Cálifornia

Three binary cycle powerplants near Mammoth Lakes produce a total of about $45 \mathrm{mega}$ watts of electricity This area is located within the Long Valley Caldera which contains numerous hot springs and other surface features of an active hydrothermalsystem Wells, each about 200 meters deep supply the binary powerplants with $170^{\circ} \mathrm{C}$ water Heat exchangers transfer thermal energy from this water to the isobutane, which vaporizes and drives the turbine generators, is then condensed and revaporized to repeat the turbine-driving cycle.

The geothermal water for this development is kept liquid by using pumps to maintain appropriate pressure and is injected through wells back inte the subsurface reservoir once heat has been transferred to the isobutane. This injection avoids problems, such as chemical precipitation, often associated with boiling of geothemal water, and it minimizes decline in reservoir pressure while maximizing recovery of thermal energy stored in the reservoir about 10 megawatts of the powerplants output is used to pump the geothermal water through heat exchangers and back into the reservoir, resulting in a net output of about 35 megawatts for customer use f fow rate of about 1,000 kilograms per second of geothermal water from the production wells is required for maximum powerplant output In general binary cycle powerplants can produce electricity profitably fromgeothermal water at temperatures as low as $100^{\circ} \mathrm{C}$

The Mammoth geothermal powerplants are built on both private and public lands $\mathrm{A}$ portion of the revenue generated from these plants is returned through taxes and royalties to local, state and Federal agencies to offet costs incurred in permitting and regulating their operation

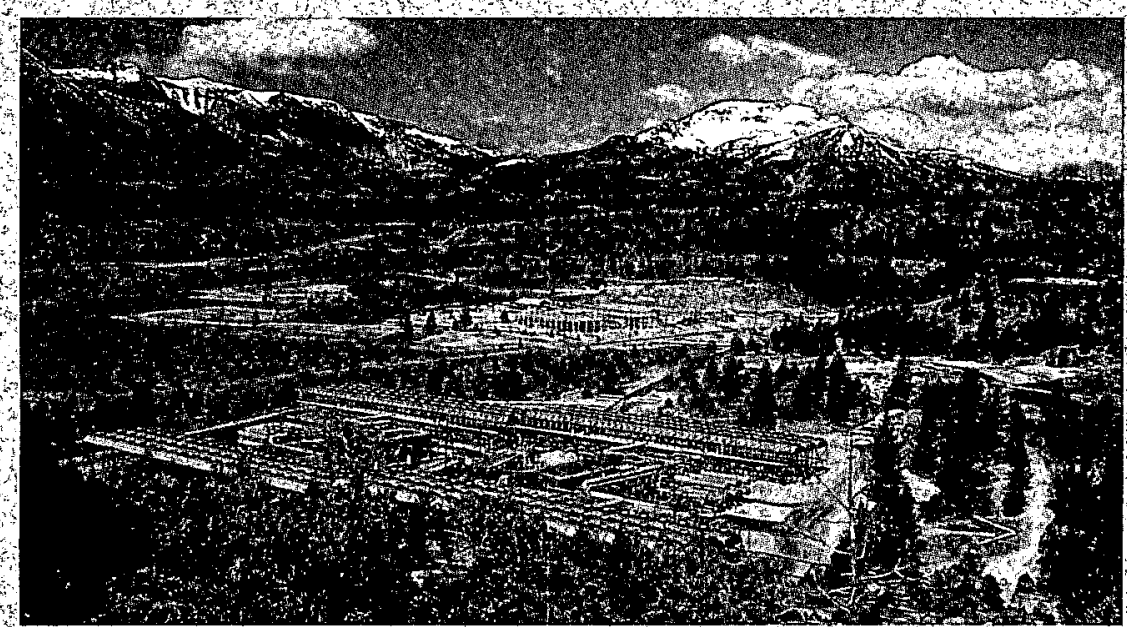

The Mammoth geothermal develop mentis in an environmentally sensitiveregion that is a popular year round resort A program designed to monitor the effects of development on the local environment has been successfully imples mented through a cooperative effort among the private developer, various regulatory agencies, and the US Geological Survey. 


\section{Warm-Water Systems: Direct Use}

Before the development of high-temperature drilling and well-completion technology, geothermal resources were limited to nonelectrical (that is, direct-use) applications. Thermal water too cool to produce electricity can still furnish energy for direct uses that range from swimming pools and spas, to heating soil for enhanced crop production at cool-climate latitudes, to

Common nonelectric uses of geothermal water as a function of temperature

Temperature (in degrees Celsius)

90

80

70

60

50

40

30

20

\section{Use}

Drying fish, deicing

Space heating, milk pasteurization

Refrigeration, distillation of ethanol

Combined space and soil heating for greenhouses

Mushroom growing

Enhanced oil recovery

Water for winter mining in cold climates

Spas, fish hatching and raising

heating buildings (Appendix 1). The total capacity for direct use currently amounts to about 1,700 megawatts thermal nationwide, substituting annually for the equivalent energy from 4.5 million barrels of petroleum. Worldwide, comparable figures are 11,300 megawatts thermal and 20.5 million barrels of petroleum. Low-temperature geothermal water is a relatively lowgrade "fuel" that generally cannot be transported far without considerable thermal-energy loss, unless piping is extremely well insulated and rate of flow through the piping is rapid. Yet, much of the world geothermal energy supply is consumed for direct-use applications. Warmwater systems - the most widely distributed of the hydrothermal systems — can locally complement or supplant conventional energy sources.

Extensive development of the warm-water systems, most commonly found in volcanic areas but also in a few nonvolcanic areas, can significantly improve the energy balance of a nation. For example, the use of geothermal water for space heating and other direct-use applications in Iceland substantially benefits the economy of that nation. Similarly, people living in Klamath Falls, Oregon, and Boise, Idaho, have used geothermal water to heat homes and offices for nearly a century, though on a smaller scale than in Iceland.

The total capacity for direct use currently amounts to about 1,700 megawatts thermal nationwide, substituting annually for the equivalent energy from 4.5 million barrels of petroleum. 


\section{Geothermal Space Heating - A Boon to Iceland's Economy}

Iceland straddles an irregular boundary between two of the Earths lithospheric plates that are mov ing apart The coun try literally grows by this plate motion (rifting) in a roughly east west diréction at an aver age rate of about 12 centimeters peryear. The plate boundary is the locus of man earthquakes active volcanoes and associated geothermal systems Because the entire country cont sists of geologically young volcanic rocks, warm water can be encountered in holes drilled al most anywhere.

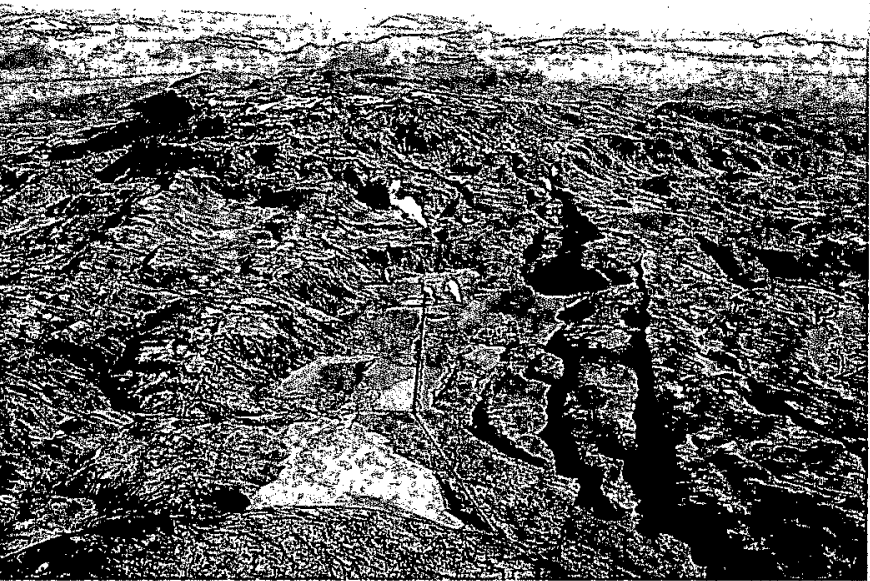

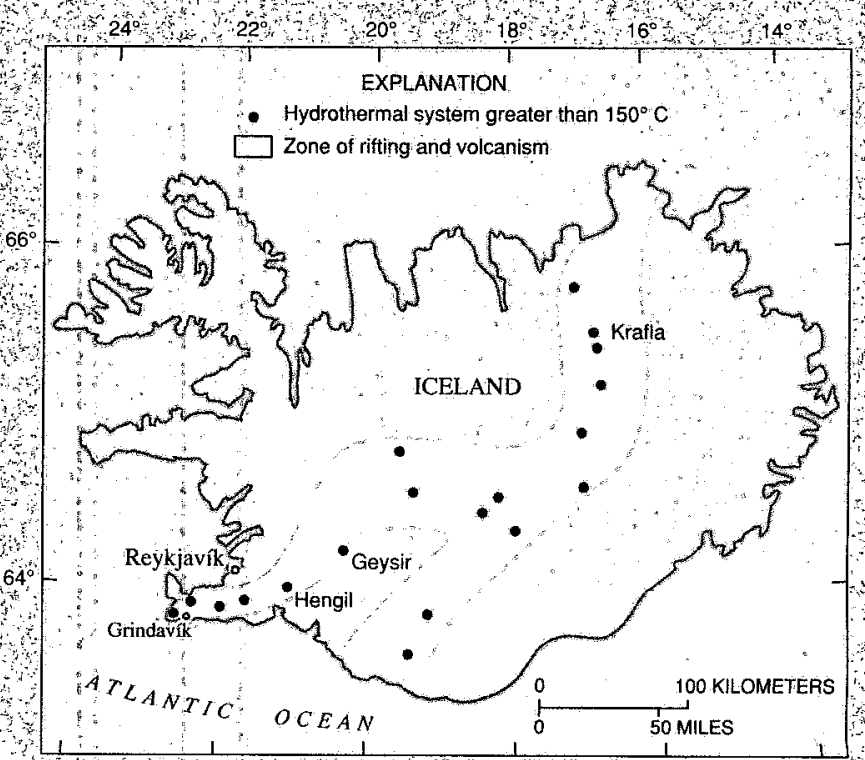
belts of active volcanoes, Iceland has abun dant geothermal resources of both electrical and nonelectrical grade The country also has abundant surface-water resources, and most of the nations electricity is generated from hydropower Nearly all buildings however, are heated with geothermal water The gether mal water (or fresh surface water heated with geothermal water through a heat exchanger) for space heating in Reykjavik the national capital, is piped as far as 25 kilometers from well fields before being routed to radiators in buildings. Very little thermâl energy is lost in transit because a high rate of flow is maintained through well insulated pipes:

Typically, the water delivered to homes and other buildings of of auality sufficent for other direct uses (for example, bathing and food preparation) in addition to space heating, and therefore is also piped to taps the size of space heating developments varies from large enough to serve the entire national capital (population of about 145,000, which is about 40 percent of the country population to appropri ately small enough for a single family residence in a rural setting Geothermal water also is used in Iceland to heat greenhouses; so that flowers and vegetables can be grown year round

Aerial view of the zone where leeland is spreading (rifting) apart Lin ear ridges and cliffs in foreground mark traces of fractures that form during rifting plumes of steam are from geothermal wells at Hengil 


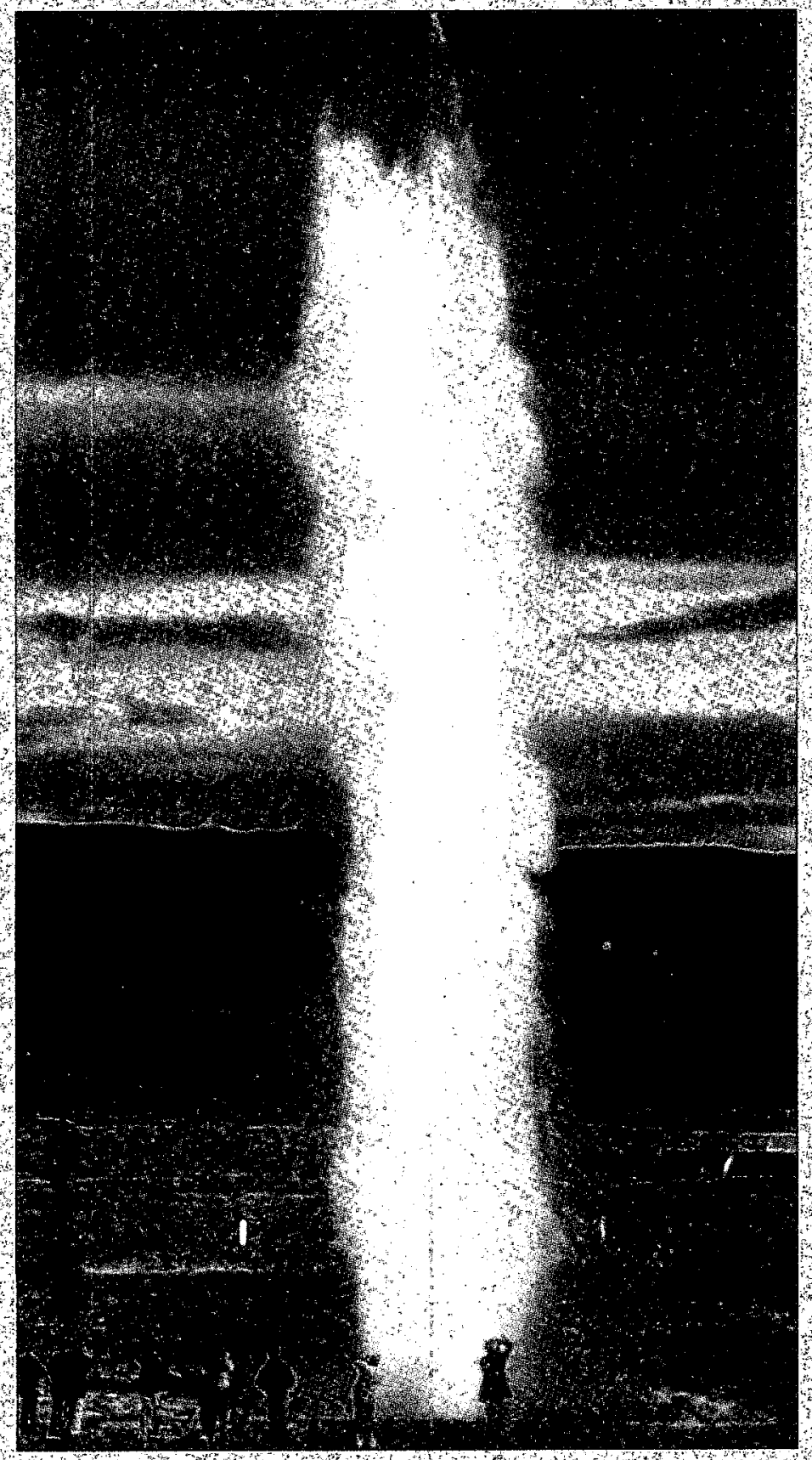

Eruption of a thermal pool whose Ice landic nâme geysir (spelled geyser elsewhere is now used worldwide for such geothermal features Geothermal water of the Geysit area is used to heat greenhouses for growing yegelables With the aid of artificial lighting int winter such greenhouses produce veg etables year roünd Copyrighted pho tograph by Barbara Decker Double Decker Press Used with permission

Interior of rotating restaitrant on top of geothermal hot water storage tanks in Reykjavik Iceland Photograph by Gudmundur E Sigualdason Nordic Volcanological Institute Reykjavik Iceland Used with permission.
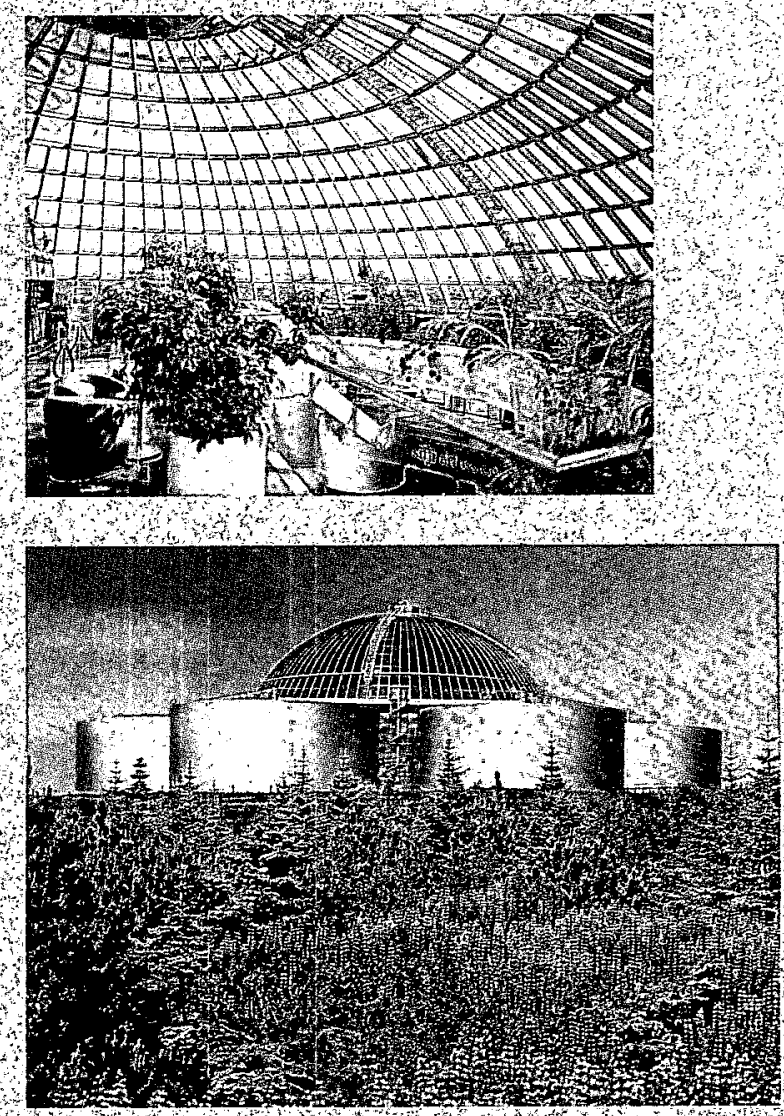

Exterior of rotating restaurant on top of geothermal hot water storage tanks in Reykjavilk Iceland Photograph by Gudmundur E. Sigualdason, Nordic Volcanological lnstitute, Reykjavi $k$ Iceland Used with permission 


\section{Direct-Use Geothermal Applications Paris, France, and Klamath Falls, Oregon}

Geothermal heat can be the dominant source of energy for direct use applications such as space heating and industral processing as in Iceland, or it can play a smaller scale but important role In the region around Paris some 13,000 apartment housing units are heated by 60 to $80^{\circ}$ E water obtained from geothermal wells about 15 to 2 kilometers deep once heat has been extracted the geothermal water is pumped back underground where it is reheated by contact with rocks.

The city of Klamath Falls, Oregon, is located in the southem part of the Cascade Range in an area of abundant near-surface geothermal water of temperatures appropriate for direct use applications For more than acentury, citizens of this community have used this resource in innovative way. Hundreds of residents tave drilled shallow wells on their property fo tap
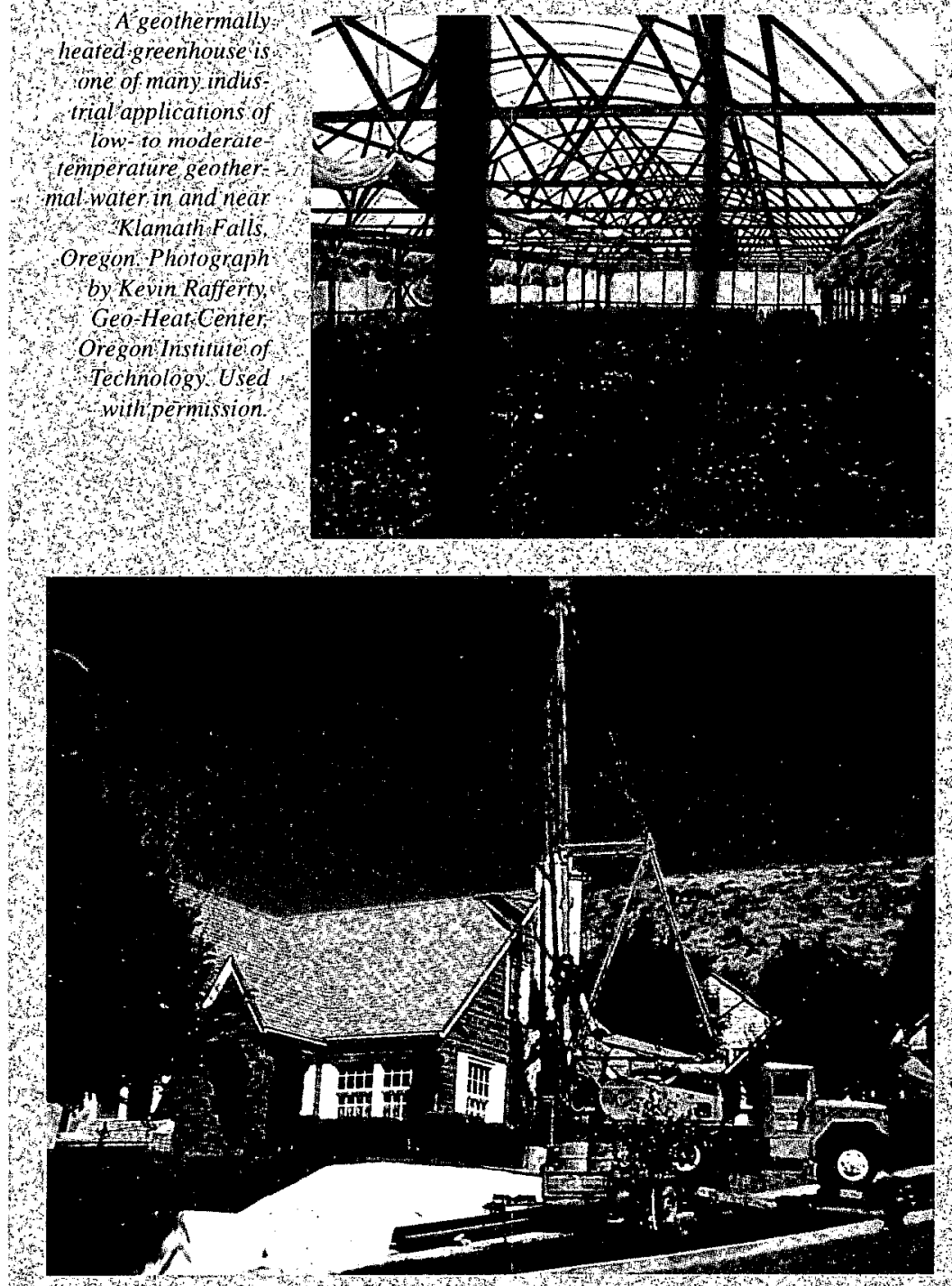
geothermal energy for home heating Commonly no hot water is pumped to the surface, but heat is instead extracted by circulating cold city water through a loop of pipe lowered into the well This technique greatly extends the life of the geothermal resource, because now water is removed from the hydrothermal system Durring winter many residents circulate warm water through pipes enbedded in the concrete of driveways and sidewalks to meltithe abundant snow that Klamath Falls usually recelves.

* large scale directuse system provides heat for several govenmment and commerciál buildings in the downtown area of Klamath Falls ncluding the Oregon Institute of Technology (OH) Geothermal water also is used by ndustry in greenhouses at fish farms, and by daines The Geo Heat Center at OIT leads the Nation in research and development related to directuses of geothermal water

A rig set up to drill a well for a single family residentiall heartexchanger system in Kla math Falls oregon Photo graph by Kevin Rafferty Geo Heat Center Oregoninstit fute of Technology Used with permission 


\section{Geopressured Systems}

A type of hydrothermal environment whose hot water is almost completely sealed from exchange with surrounding rocks is called a geopressured system; this type of system typically forms in basins that are being filled with sediment, rather than in volcanic areas. Geopressure refers to the hydrothermal water being at higher-than-normal pressure for its depth (that is, they are overpressured). Such excess pressure builds in the pore water of sedimentary rocks when the rate at which pore water is squeezed from these rocks cannot keep pace with the rate of accumulation of the overlying sediment. As a result, geopressured systems contain some mechanical energy, stemming from the fluid overpressure, in addition to the thermal energy of the geothermal water. Moreover, these systems also contain potential for combustion energy, because considerable methane gas (otherwise known as natural gas) is commonly dissolved in the geothermal water. The bulk of the thermal energy of geopressured systems is accounted for by roughly equal contributions from the temperature of the water and the dissolved methane. The most intensely studied area containing geopressured-geothermal energy is the northern part of the Gulf of Mexico; similar systems are present in sedimentary rocks beneath the Great Valley of California and the Great Plains. None of these systems has yet been commercially developed, but active research continues.

\section{"DRY" GEOTHERMAL ENVIRONMENTS}

With current technology, the abundant thermal energy in high-temperature geothermal environments lacking available water or sufficient permeability for well production-hot dry rock and magma - cannot be tapped, but these environments are the focus of considerable research to explore the feasibility of harnessing their energy. In terms of temperature, magma has the highest geothermal energy potential known. Though of lower temperature, hot dry rock is present in most drillable parts of the Earth's crust, and therefore it will be able to contribute to energy needs of broad geographic areas, if the currently experimental techniques of energy extraction are improved to a commercially competitive status.

The lack of available water in hot dry rock usually reflects a combination of low porosity and low permeability, owing to the absence of fractures or to the partial filling of fractures by mineral deposition. However, new fractures can be created by pumping water at high pressure down a drill hole to increase both porosity and permeability. The artificially enhanced fracture system then can serve as a conduit zone, through which water can flow to extract the heat contained in the hot rock; water is pumped down from the surface via an injection well and, after being heated at depth by flowing through the artificially fractured hot rock, is brought back to surface via a return or production well. The technical feasibility of this mode of energy extraction already has been demonstrated by an experiment at Fenton Hill, New Mexico. Depending on economics, the type of application, and resolution of some remaining technical problems, it might be possible to apply hot-dry-rock technology over large areas of the continents. For example, energy for space heating on a large scale can be tapped from rocks with 


\section{'Mining' the Earth's Heat}

To date, only those hydrothermal systems with a sufficiently high temperature and permeable water saturated rock have been developed However, systems having both these characteristics are not widespread Yet rocks with temperatures high enough for direct use applications, or possibly for generation of electricity, are present every where at drillable depths, whether or not they are permeable and water saturated $\mathrm{Accordingly,} \mathrm{if} \mathrm{current} \mathrm{experimental} \mathrm{techniques} \mathrm{are}$ perfected the thermal energy could be mined from those vast areas of the Earth containing sufficiently hot rock but insufficient available water Such regions potentially represent a huge inventory of geothermal energy.
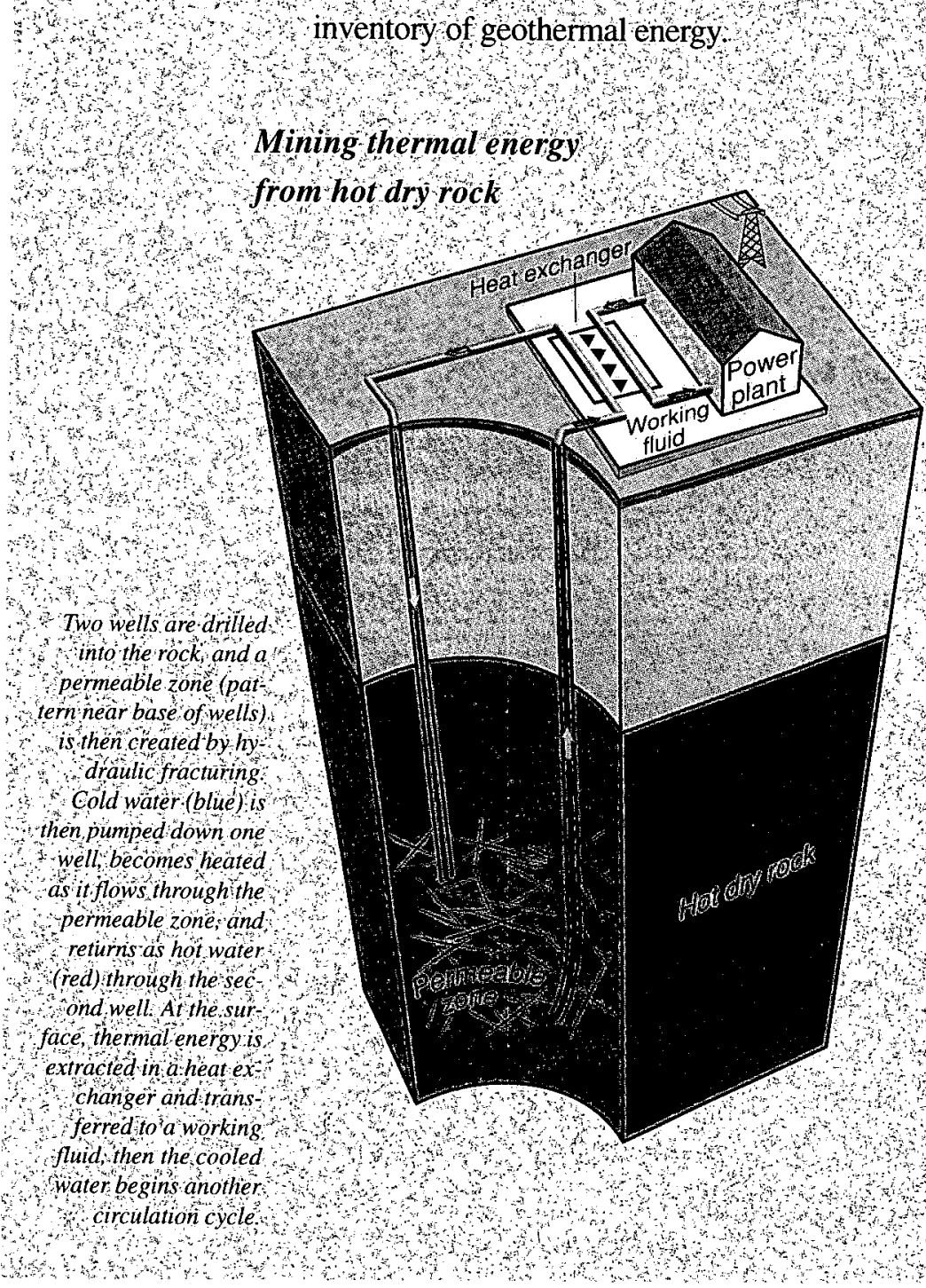

\section{HOT DRYROCK}

Research is underway at several locations world wide, and the technical feasibility of nining heat from high-temperature, waterpoor rocks has already been demonstrated büt the costs of doing so are still prohibitive. This technology has been dubbed hot dry-rock. (HDR) technology to emphasize the fact that these potential geothermal resourees are either dry or too impermeable to transmit contained water at usefil rates Necessary permeability can be and has been created with various methods (called hydraulic fracturing or hydrofracting) used in the petroleum industry to enhance the recovery of oil and gas. Hydrofracting involves the high pressure injection of a fluid (usually water) into a reservoir to crack rock and (or) enlarge preexisting openings Possible sources for the water used in hydrefracting range from tapping nearby shallow, cool ground water or surface water to using treated sewage effluent

The pioneering research and development

temperatures in the 40 to $60^{\circ} \mathrm{C}$ range, and in most continental areas, such temperatures can be expected at 2 to 3 kilometers, depths easily reached by conventional drilling. If environmental costs are considered, energy production from hot dry rock could become economically competitive in many areas of the world. 
in HDR technology were nitiated by scientists of the Eos Aiamos National Laboratory (GANL), New Mexico, 101974 To date, the EANL field experiment has involved the drilling of a par of wells (injection and production); the creation of a permeable reservol, through hydraulic fracturing, in rocks surrounding the bottom parts of the wells; and the completion of several flow tests at moderate (as much as 5 megawatts thermal) power output to demonstrate the feasibility of the technology ohis HDR experiment was conducted at Fenton Hill, near the edge of the volcanically young Valles Caldera near Los Alamos New Mexico Economic projections indicate that electricity generated by the

\section{Fenton Hill installation would cost two to}

three times as much as electricity generated by

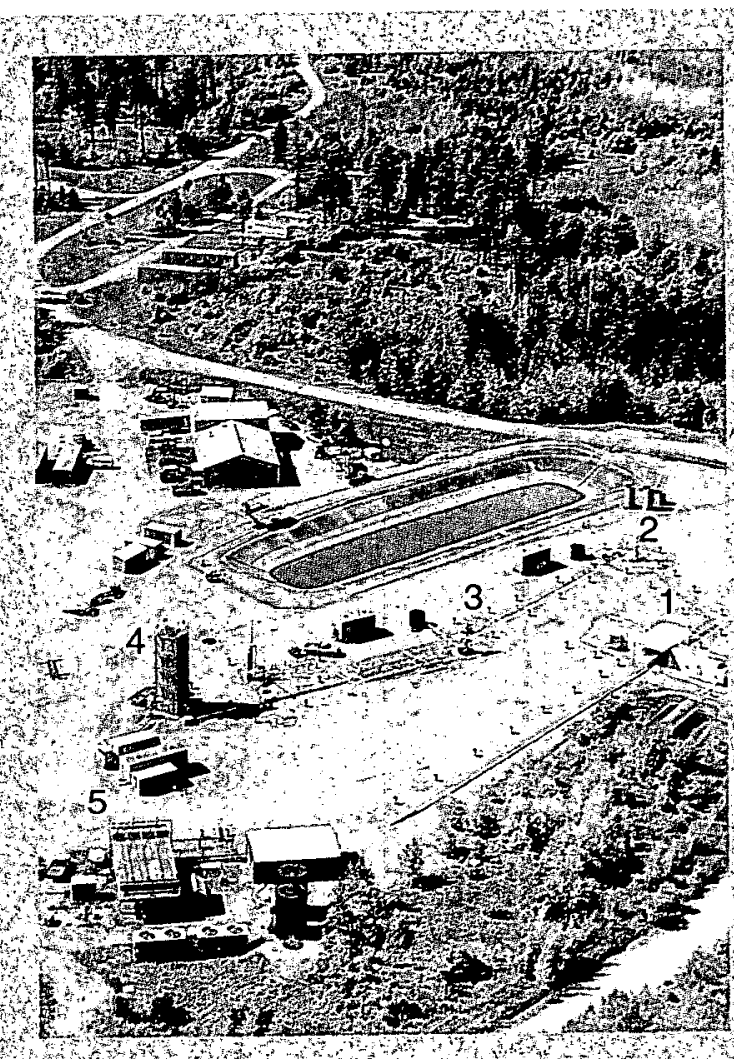

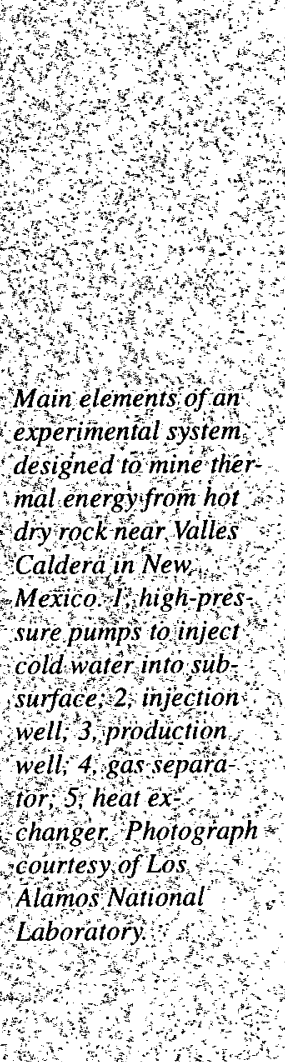
modern gas fired plants Suggested changes in production strategies, not yet-field-tested, could reduce this margin considerably fif long-termenvironmental costs are considered in a compar son of energy producing means the cost effectiveness of HDR technology is greatly increased. Althoügh research at Fenton hill has been focused on energy outputs and temperatures appropriate to generate electricity, the HDR technology is also applicable to direct uses, such as spaceand pocess heating Pilot project in Britain, central Europe, and Russia are directed toward these lower temperature applications

\section{MAGMA}

Rock materals in the Earth's crust that are molten called magmo have the highest heat content, with temperatures that range from about 650 to $300^{\circ} \mathrm{C}$ Applying terminology from the minumg ndustry, magna is the purest form (or highest grade) of geothermal ore, Magma is, in fact the ultimate source of all high temperature geothermal environments in the crust (including both wet or hydrothermal systems and dry systems or hot dry rock),

The size, distribution, and frequency of volcanic eruptions provide directevidence that magma s widespread within the crust Much of this magn is within about 5 kilometers of the

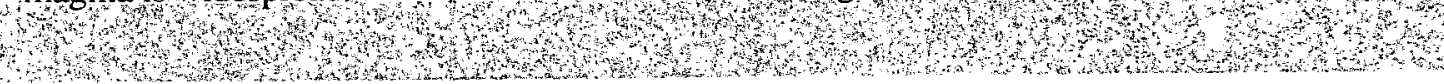

In contrast to the widespread potential of hot dry rock, energy from magma could be obtained at only a few sites. However, if significant technological problems are overcome, a large amount of energy could be extracted from these few sites because of the high temperature of magma. Conceptually, harnessing magma heat is straightforward: drill a hole into a 


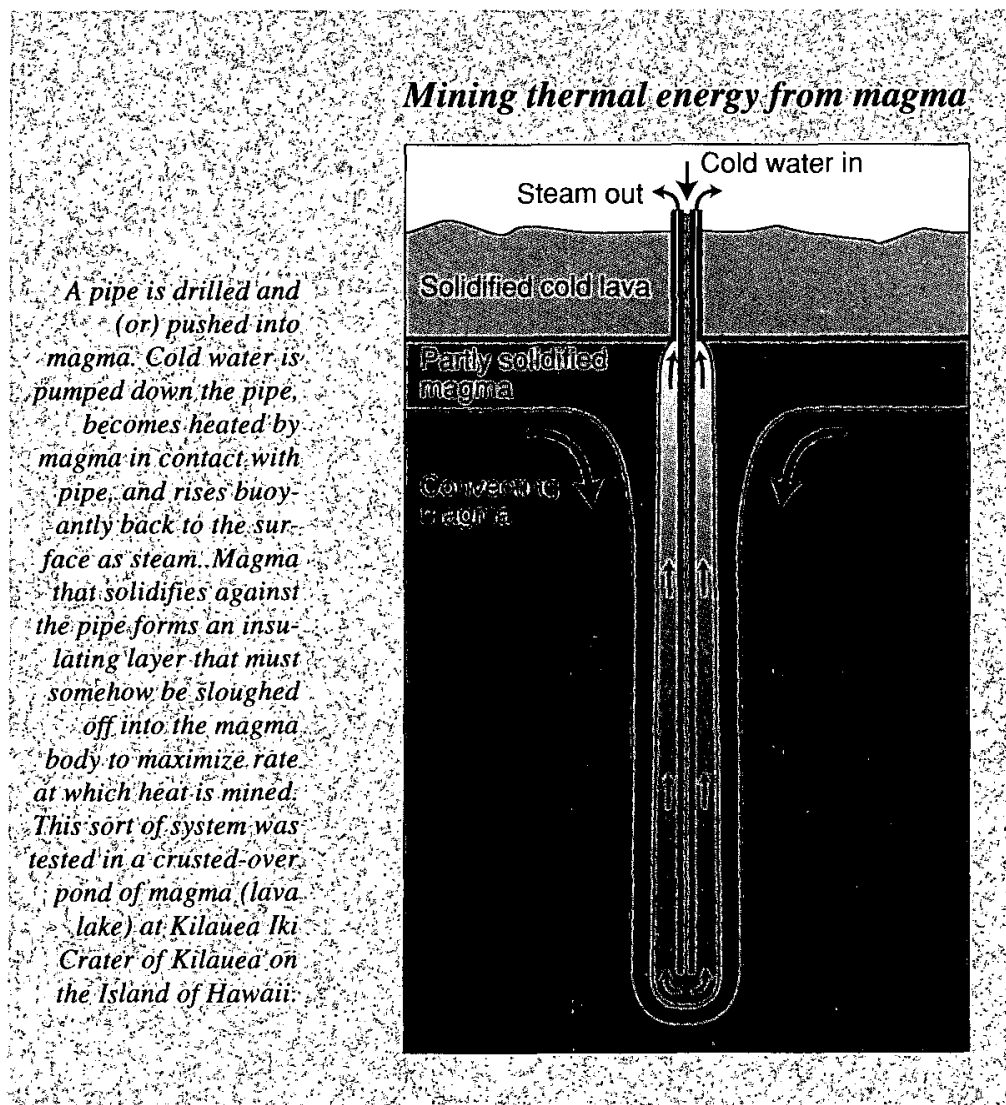

surface - depths easily reached using current drilling technology. The 15 cubickilometers of magma erupted in 1912 to produce the ollcanic deposits n The Valley of Ten Thousand Smokes, Aláska, was probably at drill able depth before enuption Had it been possible to mine this magma's thermal energy before enuption, using heat exchangers lowered into the magma through drill holes the output would have been the equivalent of about 7,000 megawatts of electricity for a minimum of 30 years equal to the combined power of 7 hydropowerstations the size of the one at Glen Canyon Dam Arizona, producing at top eapacity for 30 years.

The economic mining of useful energy from magma is not likely to be achieved any time soon, even though technical feasibility to do so has been examined theoretically and demonstrated both in the laboratory and in the field The field experiments were carried out during the 1980 's within the still-molten core of a lava lake that formed in Kilauea Ik Crater Hawai, 1959 The long-termeconomic of mining hea from magma are unknown at least in part because of uncertainties in the expectable life span of materials nicontact with magma during the mining process Finding materials that can withstand extremely high temperatures and the corrosive nature of magma is one of the main obstacles to overcome before magma energy technology can be widely tested Scientists at the Sandia National Laboratory, New Mexico are leaders in the field of research and development devoted to solving these problems

Another impediment to tapping the thermal energy contained in magma is in unambiguously locating the magma body before drilling begins Although experts agree that many bodies of magma are within the drillable part of the Earth's crust, their exact locations can be verified only, by drilling, and drilling expensive. The possibility of the drill missing the target adds to the uncertainties related to longevity of materials in a hot comrosive environment For the present; these uncertanties definitely make mining of magma heat a high-riskendeavor using this highest grade of geothermal ore

magma body and then circulate a fluid, probably water, through a heat exchanger at the bottom of the drill hole. This process presumably would extract the thermal energy released over several decades as the magma cooled and crystallized to form solid rock. There are, however, many technical questions that must be answered before the magma-energy option can be exer- 
cised. For example, for thermal efficiency, fresh hot magma must continually be brought into contact with the heat exchanger, otherwise magma will solidify against it and form an evergrowing layer of insulating rock that, if not periodically removed, would in time greatly reduce the heat-extraction rate. Can such removal of solidified material be done? It may occur naturally, if the cooled layer of solidified magma forms shrinkage cracks and splits away from the heat exchanger; physical agitation of the exchanger could help this process.

There are other major challenges to developing magma energy. One challenge is the unambiguous and precise location of target magma bodies. Another is the development of materials that can withstand the hot and chemically corrosive magma environment over the long term. Nonetheless, during the 1970's, successful drilling-based experiments were conducted in a body of solidifying magma (lava lake) that accumulated within Kilauea Iki Crater in 1959, at the summit of Kilauea on the Island of Hawaii. The drilling, using conventional methods, was relatively easy because magma was only a few meters below its capping crust, and the feasibility of using a water-based heat exchanger in magma was demonstrated.

\section{Conceptually, harnessing magma heat is}

straightforward: drill a hole into a

magma body and then circulate a fluid,

probably water, through a heat ex-

changer at the bottom of the drill hole. 


\section{Geothermal Studies at the U.S. Geological Survey}

ince 1971, the U.S. Geological Survey has participated in a large, multiagency Federal $N$ Geothermal Program through its Geothermal Investigations Program. The impetus for the Federal Geothermal Program was recognition that the uneven distribution of petroleum resources worldwide leaves most industrialized countries, including the United States, being heavily dependent upon imported fuels. Initially, the most urgent task of the Federal program was to develop data and methods to assess and inventory the Nation's geothermal resources, as a means of documenting the amount of geothermal energy that could potentially contribute to national energy needs.

The U.S. Geological Survey was well-suited to take on this task because of its years of previous research on hot springs and related hydrothermal mineral deposits. During the course of such research, the existence of two fundamental types of hydrothermal systems (hot-water and vapor-dominated) was discovered, and a basic understanding of how they work was learned. Accordingly, case studies of a hot-water system at Long Valley, California, and a vapor-dominated system at The Geysers, California, were developed. Many geochemical, geologic, geophysical, and hydrologic techniques that are widely used today were developed, tested, and improved during these studies. For example, geochemical techniques were devised to reliably determine the maximum temperature in the deep subsurface of a hydrothermal system from the chemical composition of spring water sampled at the surface. Information on subsurface temperature is indispensable in quantitative assessments of geothermal resources and is extremely valuable in making decisions about drilling during geothermal exploration and development.

The principal goals of the Geothermal Investigations Program are: (1) to understand the different types of geothermal environments, (2) to determine their geophysical, hydrologic and geochemical characteristics, and (3) to apply the information to quantitative national assessments of geothermal resources and to monitoring of possible environmental impacts from geothermal-energy development. Some of the principal activities toward achieving these goals are summarized in Appendix 2.

... the existence of two fundamental types of hydrothermal systems was discovered, and a basic understanding of how they work was learned. 


\section{Hot Springs 'Remember' Their Deeper, Hotter Origins}

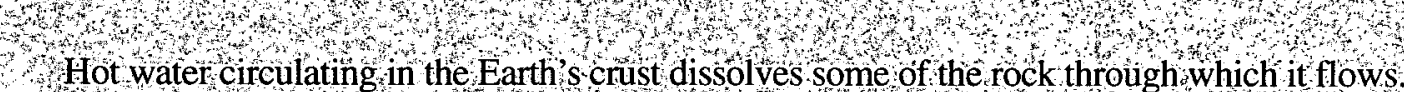
The amounts and proportions of dissolved constituents in the water are a direct function of temperature Thus, if water from ay drothermal system rises to the Earth's surface fast enough, its chemical composition does not change significantly and bears an imprint of the subsurface temperatures Field and laboratory studies sow that this deeper, hotter temperature is commonly remembered by thermal waters of hot spings Subsurface temperatures calculated from hot spring water chemistry have been confined by direct measurements made at the base of holes drilled at many locations world wide, The technique of determining temperature from the chemis try of hot spring water is called chemical geothermometry

Quartz is a common mineral in the Earth's crust and has almost ideal characteristics for chemical geothermometry The solubility of quartzis strongly temperature dependent, dissolved quartz does not readily react with othercommon dissolved constituents, and dissolved quartz precipitates yery slowly as temperature is lowered. The quartz geothermometer is especially úseful in the range of about 150 to $240^{\circ} \mathrm{C}$. If upflowing geothermal water mixes with cool shallow ground water, or partly boils in response to decreasing pressure, appropriate adjustments must be made to the calculated subsurface temperature

Feldspars the most common minerals in the Earth crist contribute the element's sodium, potassium and calcium to geothermal waters, in ratios also dependent on temperature An advantage of dealing with ratios of elements is that dilution by mixing with cool shallow ground water and boiling change the ratios litte, if any the ratio between the elements magnesium and lithium, which are also introduced into geothermal water from dissolution of rock, has also proved to be an accurate geothermometer

Isotopes (atoms of the same chemical element but with different atomic weights) of individual elements also distribute themselves according to temperature for example, yirtually all hy dro thermal waters contan dissolved sulfate, and isotopes of oxygen distribute themselves between the sulfateand its solvent, water according to a temperature-dependent relationship that can also indicate the subsurface temperature of a hydrothermal system, in practice, scientists generally use a combination of geothermometers, rather than relying on any single one, to deternine subsurface tempera ture from the chemical composition of hot spring watertin so domg, uncertainties associated with results obtained using only one method may be reduced or resolved with reference to the results from other methods

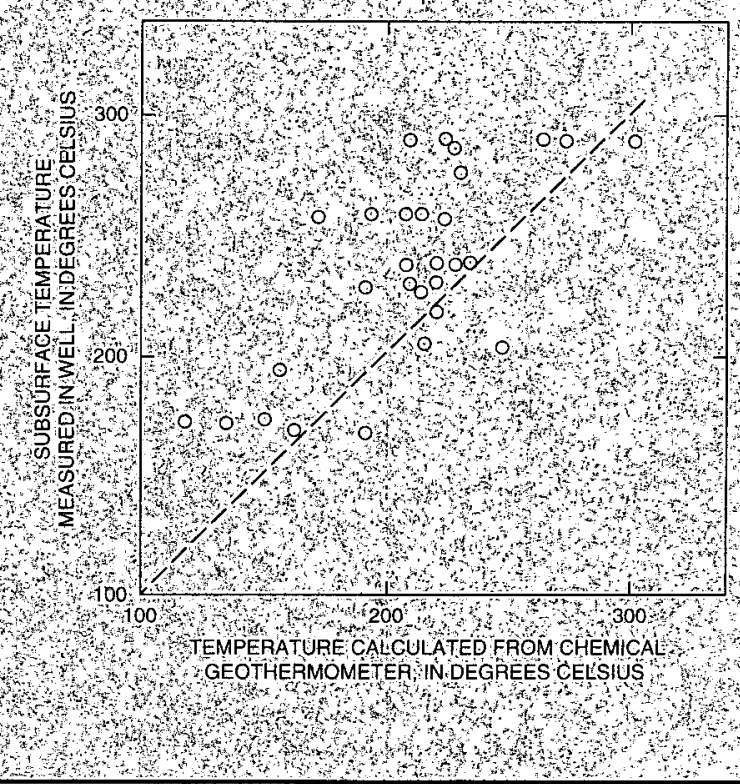

Graph of tempera tures measured in wells drilled into hy drothermal systems versus temperatures calculated from com positions, of hot spring wateror steam, before drilling Dashed line shows where points should plot if measured and calculated values agreed perfectly Dots somewhat above this line show that calculated temperatures tend to slighily under estimate measured temperatures, but still arevery useful in guiding exploration strategies 


\section{ASSESSING THE NATION'S GEOTHERMAL RESOURCES}

The Geothermal Investigations Program completed the Nation's first well-documented assessment of geothermal resources in 1976 and prepared an updated and expanded assessment in 1979. Both assessments involved the determination of the location, size, and temperature of hundreds of geothermal systems to estimate the amount of heat stored in subsurface reservoirs of hot rock and water, as well as the fraction of stored heat that might be brought to the Earth's surface for utilization.

In developing a data base for the assessments, nearly all known hot springs of the United States were sampled and chemically analyzed to permit calculation of subsurface temperatures. Because the size (volume) of a geothermal system is not often apparent from surface features, geophysical techniques were developed to help determine the subsurface configuration (size, shape, and temperature) of a hydrothermal reservoir. Determination of subsurface electrical conductivity can be particularly effective for outlining the extent of hydrothermal water. In addition, temperature was measured in many drill holes to delineate broad regions of high heat flow, which are most likely to contain geothermal targets. As a result of these and related studies, more than 200 hydrothermal systems were identified that could yield water (or steam) hot enough for electrical generation.

In discussions of geothermal-resource assessment, the word "resource" carries a very specific and restricted meaning for energy specialists. In quantitative assessments, "geothermal resource" explicitly refers to the thermal energy that could be extracted from the ground at costs competitive with other forms of energy within a foreseeable time frame, under reasonable assumptions of technological improvement and economic favorability. Within this context, all geothermal resources today are restricted to the hydrothermal environment.

The U.S. Geological Survey's assessments made in the 1970's indicated that the Nation's geothermal resources are much greater than the amount then being developed. The resource represented by known hydrothermal systems with temperatures capable of generating electricity is equivalent to about 23,000 megawatts electric for a nominal life of 30 years. Inferred, but as yet undiscovered, hydrothermal systems are estimated to contain up to 150,000 megawatts electric for 30 years. For comparison, the installed generating capacity of a typical nuclear powerplant, as well as that of the hydropower development at Glen Canyon Dam on the Colorado River, is about 1,000 megawatts electric.

\footnotetext{
As a result of these and related studies, more than 200 hydrothermal systems were identified that could yield water (or steam) hot enough for electrical generation ... known hydrothermal systems with temperatures capable of generating electricity equivalent to about 23,000 megawatts electric for a nominal life of 30 years.
} 
With further data and refinement in the methodology for calculating resources, the U.S. Geological Survey published in 1983 a national assessment of low-temperature hydrothermal resources (less than $90^{\circ} \mathrm{C}$ ). Although these resources are too cool for the generation of electricity, they are efficient providers of heat for direct-use applications. These resources are estimated to contain 87,000 megawatts thermal for a nominal period of 30 years.

For the United States, the distribution of hydrothermal systems is known well enough to indicate where the geothermal component can -in the near future-most effectively contribute to the national energy mix. Over the longer term, however, if technology breakthroughs are realized, a large addition to the energy mix could come from the environments of hot dry rock and magma, neither of which can currently be considered resources as strictly defined. The thermal energy represented by these environments is 1,000 times or more than that known to exist in hydrothermal systems. Even if a small fraction of this energy could be brought into the resource category, the contribution to national energy needs would be substantial.

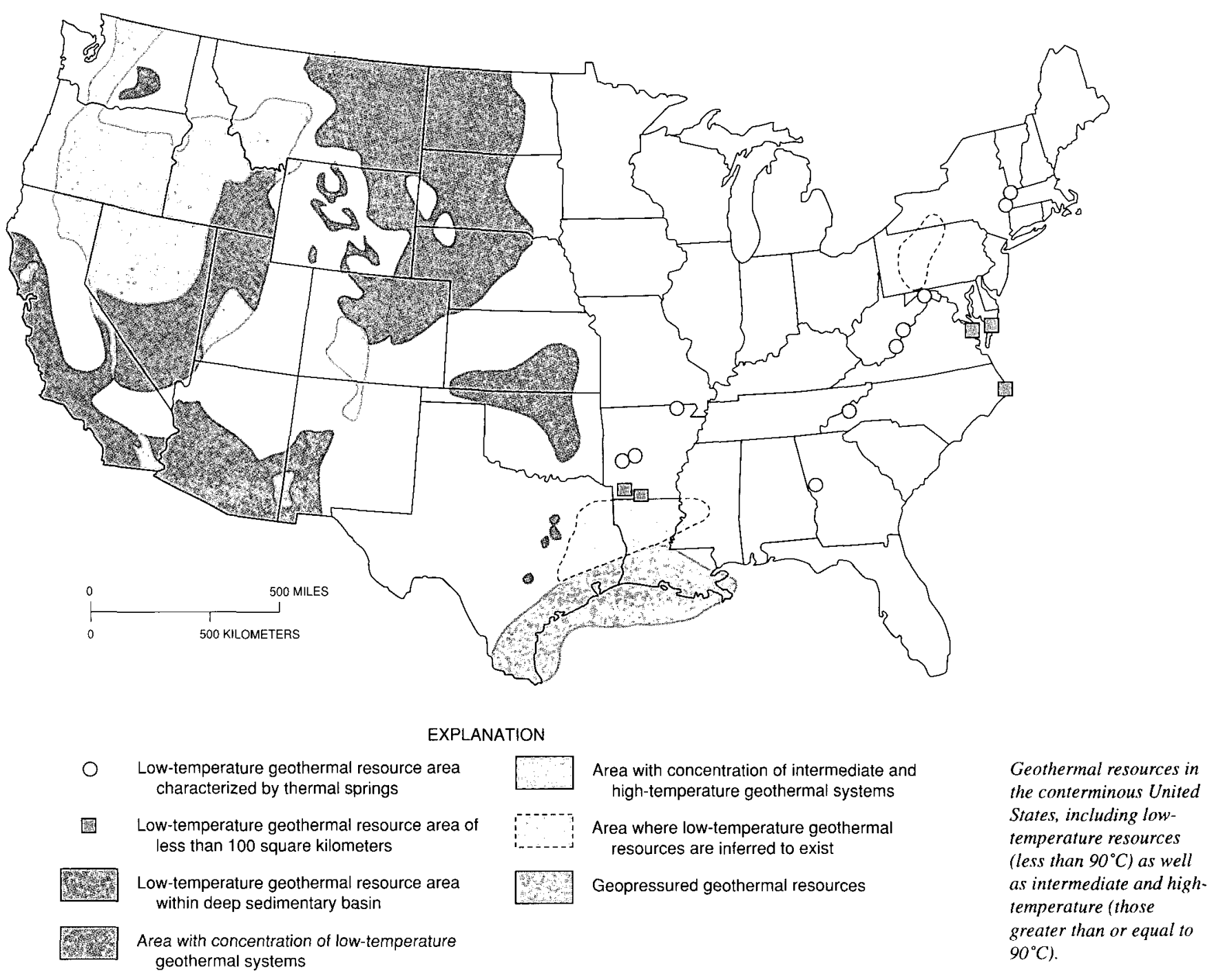




\section{'Seeing' Beneath the Earth's Surface}

Different types of rocks have different physical properties To detect variations in rock properties at depth, geophysical measurements can be made at or above the Earth's surface When combined with the results of geologic, geochemical, and hydrologic studies geophysical

$*$ geophysical data provide a three dimen sional view into the Earth's crust

Geophysicist making gravity measurement in the Sierra Nevada near Long Valley, californio Such dato are usefullfor helping to locate geologic structures and locat ing bodies of magma below the Earth's sir face photographby Carter Roberts.

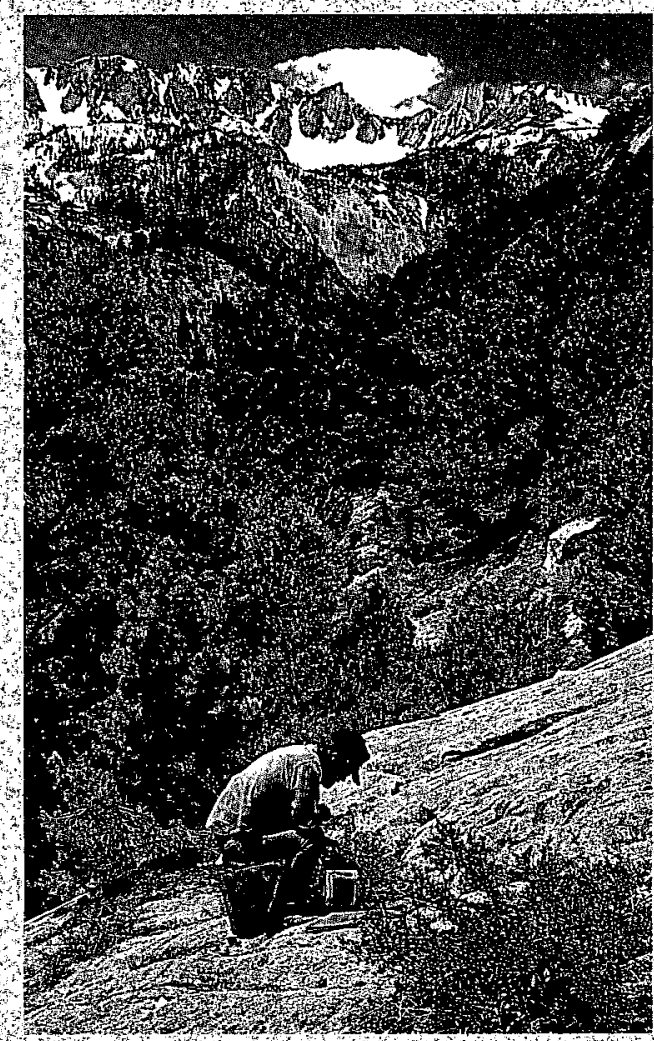
surface. data provide a three dimensional view into the Earth s crust Various geophysical methods have long been used to explore for minerals and fossil fuels, however their application to geothermal exploration is a rélatively recent endeavor Some methods can be used to determine the locations and nature of subsurface faults or porous zones that may act as pathways for circulating geother mal water or steam, others can provide information about the temperature variation in the crust

Subsurface temperature data are particularly useful because most physical properties of rocks vary with temperature Geophysicists have developed techniques to estimate the general size and shape of hydrothermal systems, and to locate bodies of magmar hot solid rock that are likely sources for heat that drives such systems

Seismology is the study of seismic waves that pas through the Earth Seismic waves originate from earthquakes or other sources (explosives for ex ample) and are; detected at the Earth's surface with nstruments called seismometers. Because some rock transmit seismic waves faster than others and beceuse seismic velocity slows with ncreasing rock temperature, seismievelocity data can give clues about rock ty pe, geologic structure, and temperature beneath the

Seismic tomography is a technque that produces a threedimensional image of the Earths subsurface Tomography s widely used in medicine where for examples sound wavesare used to image internal parts of the human body Similarly, to obtain an image the Earth interior, seismic waves from natural and artificial sources are recorded by seismometers distributed throughout an area of interest and analyzed by computer Seismic tomographic experi ments, which generally last for weeks to months, have been conducted at several volcanic and (or) geothermal areas (for example, Medicine Lake, Long Valley, and Coso California), where zones of sow seismic velocity provide evidence for crustal magma bodies.

Geomagnetism is the study of the Earth' magnetic field Some minerals, particularly ron oxides, are magnetic at temperatures prevailing in the shallow erust. Rocks containing magnetic minerals contribute to the overall magnetic field of the Earth Accordingly, surveys of the Earth s magnetic field commonly carried out from aircraft provide information about the location and shape of tocks With unusual magnetic properties. Areas having geothermal potential are most common in regions of geologically y oung volcanic rocks Because volcanic rocks are highly magnetic, geomagnet ic surveys can be particulary useful in geothermal explóration Laboratory experiments show that rocks contaning the most common magnetic minerals 
1 se their magnetization at about $580^{\circ} \mathrm{C}$, the Curie temperature, and the depth to crust with this temperature can be calculatted from geomagnetic data Regions characterized by shallow Eurie-temperature depths tend to have geothermal potential, and these often are the targets of more detailed geophysical and geochemical exploration studies

The ability of the Earth's crust to conduct electricity depends mostly on pore spaces in rocks and the chemical compositions of fluids and hydrothermal minerals within those pores. Geophysicists can map the electrical stuucture of the crust by monitorng the Earth's selectromagnetic field as it responds to natural for example lightning strikes and artificial electrical pulses. Parts of the crust that contain hydrothermal systems generally are highly conductive relative to surrounding, colder rock

Varations in rock density in the Earth scrust produce measurable varations in the strength of the gravity field as measured at the surface Variations in density can be interpreted in terms of geologic features that may indicate geotherual potential For example, at tong Valley, Califor nia a arge area of relatively low gravity corresponds almost exactly to the caldera delineated by surface geologic mapping Thus gravity data furmish independent evidence about the size, Shape, and 1ocation of the caldera, as well as a semiquantitative neasure of the thickness of low density rocks within and beneath the caldera Rock density depends only slightly on tempera. ture, but molten magma is generally muchless dense than the rock solidified from $\mathrm{t} / \mathrm{n} \mathrm{prm}$ ciple therefore, gravity surveys ean detect shallow crustal magma bodies the gravity low at Long Valley may be caused in part by magna and a gravity low over The Geysers geothermal field win ealifornia may also be partly related to the presence of magma.

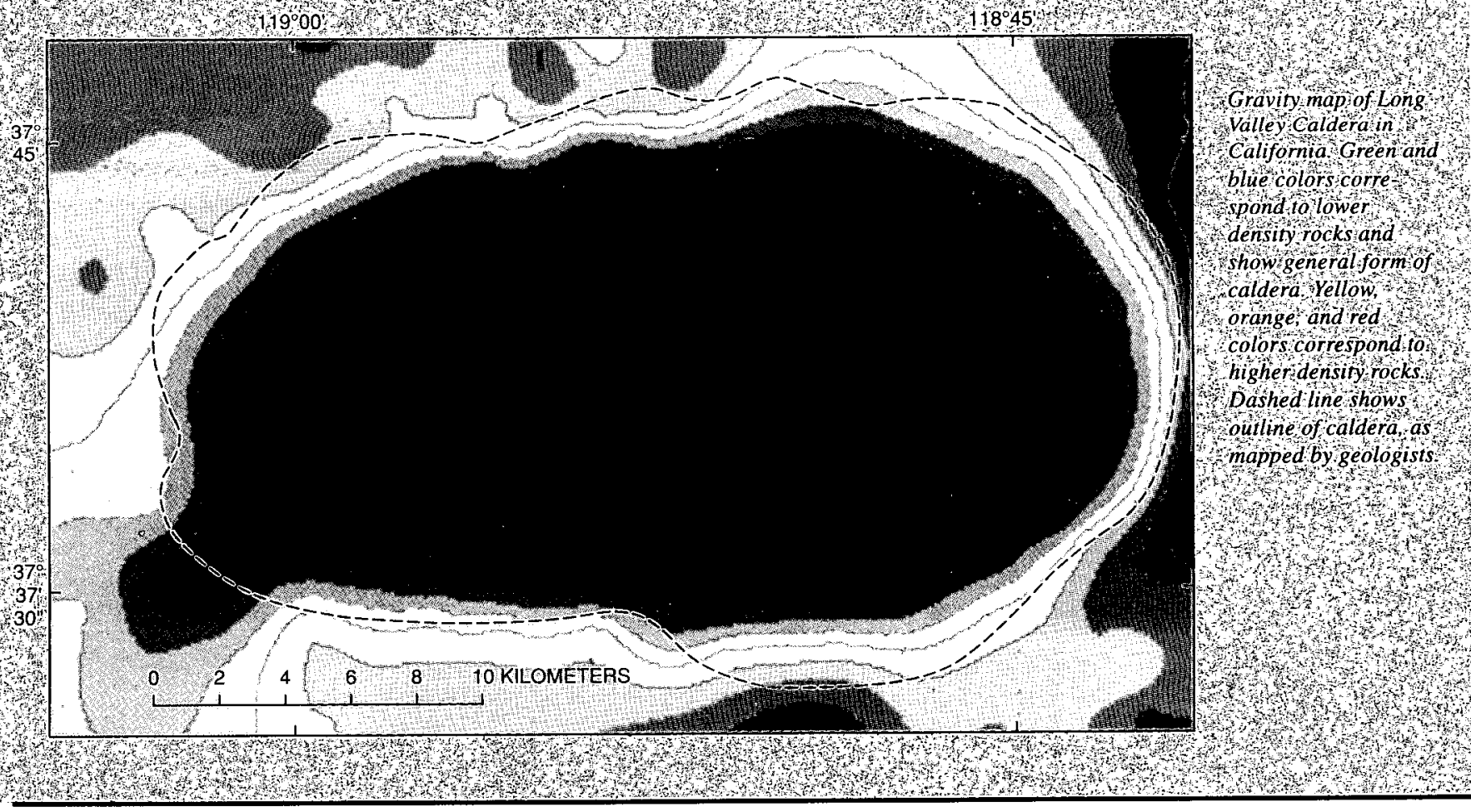




\section{Geothermal Resource Assessment How Much of the Earth's Heat Can Be Tapped?}

Although the Earth sheat is inmense, only afraction of it can be harnessed But how large is this fraction? In trying to answer this important question, scientists must use an approach called geothermal resource assessment This approach nvolves deter mining how much geothermal energy might become available for use in the future, given reasonable assumptions about technological advances and economics

For assessments of geothermal energy to be comparable to assessments made for other energy resources, the same methodology and terminology must be compatible In assessing geothermal resources, the $\mathrm{U}$ S Geological Survey has adapted methods and terms already being used by the energy and ming ndustries Within the context of $\mathrm{a}^{+}$ resource assessment, the term resource is narrowly defined and takes on a meaning much more specific than in ordinary writing or conversation

A graphical representation of concepts and terminology commonly used in resource assessments is shown by the McKelvey Diagram, named for the late vincent $\mathrm{E}$ McKelvey, former Director of the $\mathrm{U}$ S Geological Survey For geothermal resource

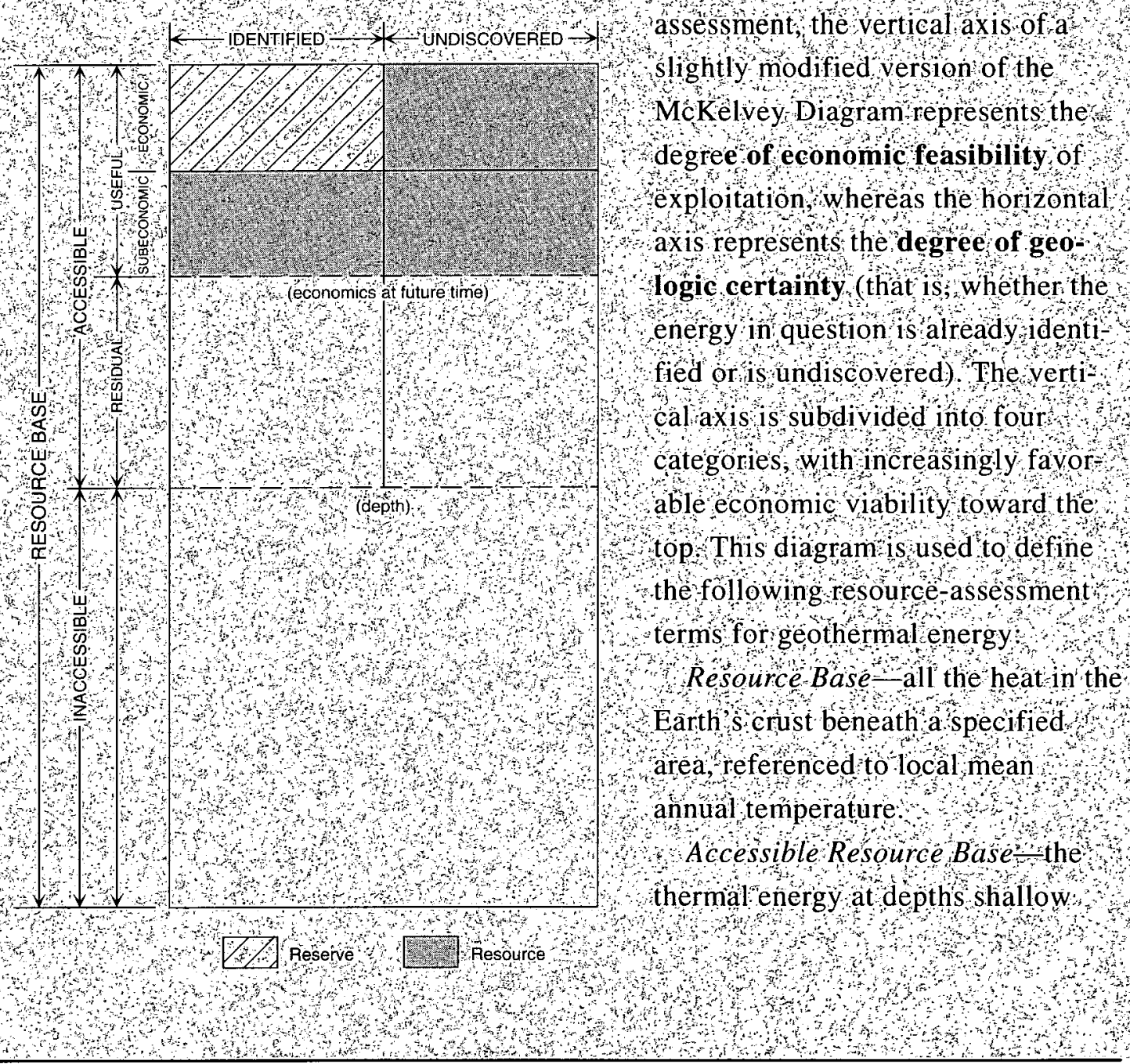


enough to be tapped by driling using technology available at present or within the

foreseeable future.

Resource that part of the accessible resource base that is producible given reasonable assumptions about future economics and technology

HRerve mthat part of the resourcethat tontified and is producible withexisting technology and under present economic conditions

TUSing the terminology above the $\mathrm{US}$ Geological Survey has estimated the geother mal resources of the United States, exclusive of national parks (see suggested Addi tional Reading" section) dentified geothermal resources at temperatures greater than 150 C Were estimated to be sufficient to generate 23,000 megawatts of electricty for 30 y ears. This transiates to 30 years of electricity at average uban rates of usefor about 23 million people in the United States In addition, identified geothermal re sources at temperatures less than $150 \%$ are estimated to be 280,000 megawatts of thermal energy for 30 years the equivalent of almost 20 years of oil imports by the United states at 1992 levels. These resources are appropriatefor nonelectrical uses such as space heating, industrulprocessing, and other direct ise applications, although some with temperatures above about 120 C could also be used to generate electricity using binary technology

These resource estimatesare minimum values of what geothemal can contribute to the Nation's energy consumption If estimates of undiscovered resources areconsid ered the total resource increases several fold/The great challenge for geothermal explorationists is to devise techniques and strategies to discover hiddenhydrothermal deposit that must exist but are not obviously expressed at the Earth surfacedMore over alarge amount of thermalenergy esdes in hot dry rock, which currenty lies on anuncertain category between resource and accessiblé resource base promising

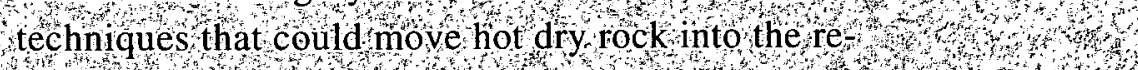
source categoryare being developed and tested.

Geothermal is unlikely to replâce fossilfuels as a dominan energy source for the United States, yet it can make a significant contribution to our energy mix: When environmental effects are factored intolong term costs, geothermal becomes even more economically attractive. Wdespread recognition of this concept could norease the potential contribution of geothermal resources as a source of alternative energy
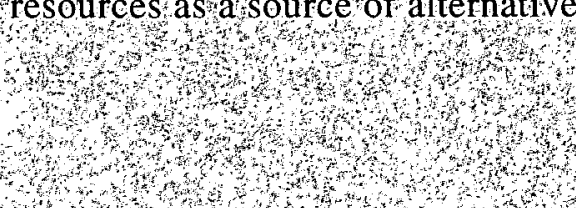

The great challenge for geothermal explorationists is to devise techniques and strategies to discover hidden hydrothermal deposits that must exist but are not obviously expressed at the Earth's surface.

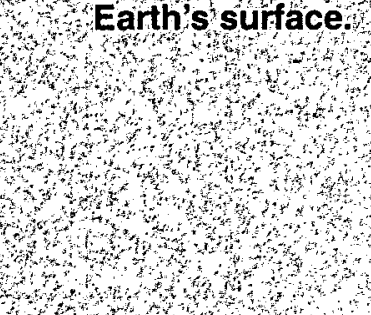




\section{GEOTHERMAL-ENERGY DEVELOPMENT}

The development of geothermal energy in the United States is ultimately the responsibility of the private sector. Traditionally, this development has involved collaboration among utility companies, energy companies, and venture capitalists, with minimal involvement of government at any level. During recent decades, however, the U.S. Department of Energy (DOE) has become an active research partner in formulating exploration strategies and development of drilling and production technologies, especially as related to the hottest and chemically most hostile geothermal environments.

For its part, the U.S. Geological Survey contributes research expertise in resource characterization and assessment. Scientists of the U.S. Geological Survey have long been mapping volcanic and other terranes of high heat flow. They also characterize and monitor the hydrology of areas with known or probable geothermal potential. They additionally apply state-ofthe-art geophysical and geochemical techniques during studies of resource potential to determine possible adverse environmental impacts of geothermal development. Scientists of the U.S. Geological Survey conduct cooperative research with specialists of the DOE-supported laboratories as well as with scientists of other government agencies. The results of such research are shared with industry and other interested parties.

In general, industry - by tradition and motivation-is disinclined to take the lead on longterm, systematic research on the development of alternative energy sources, including geothermal. To date, successful studies of alternative energy sources have relied strongly on productive collaboration between the private and public sectors. In the field of geothermal energy, the U.S. Geological Survey can best contribute to this kind of fruitful private-public working relationship by continuing integrated field and laboratory investigations of the fundamental processes associated with all types of geothermal environments.

\section{RELEVANCE TO OTHER GEOLOGIC STUDIES}

Apart from providing specific information about an energy resource, geothermal studies are also relevant to other geologic issues of national concern. Because most geologic processes are ultimately driven by the Earth's internal heat engine, geothermal research contributes to an understanding of such natural phenomena as mineral-deposit formation, earthquakes, and volcanic eruptions.

The large volumes of thermal water that circulate within the upper few kilometers of the Earth's crust are not only prime targets for geothermal-energy development but are also the agents that form a variety of mineral deposits, including those of gold, silver, lead, zinc, and copper. Circulating hot water partly dissolves the rock through which it flows, only to redeposit the dissolved chemical constituents elsewhere in response to changing physical and chemical conditions. In extreme situations, such as those inherent in some hydrothermal systems in the Imperial Valley of southern California, dissolved constituents are so plentiful that they are re-deposited as mineral encrustations along piping and other equipment of powerplants. In the short term, such mineral deposition (scaling) is an unwanted consequence of energy 
production that requires special treatment to minimize damage to plant equipment. Yet, over geologic time, similar processes occurring beneath the Imperial Valley will create valuable metallic mineral deposits. Explaining the formation and distribution of these and older mineral deposits in the geologic record depends on a thorough understanding of how hydrothermal systems function.

The rupturing of rocks under geologic stresses to trigger earthquakes is influenced by rock temperature. Thus, knowledge of the temperature distribution within the Earth's crust also provides information about the potential distribution of earthquakes. Detailed surveys of heat flow along fault zones furnish data important to understanding the behavior of individual faults and the occurrence of earthquakes. For example, measurements of heat flow along the San Andreas Fault Zone in California produced the surprising result that little or no frictional heat has been generated during past episodes of the rocks sliding past each other. This discovery required reevaluation of a long-held view that rock surfaces in direct contact along faults present great frictional resistance to earthquake-related slippage.

Most high-temperature geothermal systems are in regions of recent volcanism. Assessments of geothermal resources in such regions necessarily involve detailed studies of volcanoes and their eruptive histories, which in turn yield important insights about the magma bodies that feed volcanic eruptions as well as provide heat for geothermal systems. Thus, information critical to volcanic-hazards studies can be a cost-effective derivative benefit of geothermal studies, or vice versat. The common theme that links these various earth-science fields is the movement of magma and its associated heat through the Earth's crust.

A powerful geologic research tool, as well as the sole means of tapping geothermal energy, is the drill rig. In addition to contributions in the characterization of geothermal systems, drilling can also provide ancillary geologic information, core samples of subsurface rock for laboratory study, and allow direct calibration of interpretations of surface-based studies. In recent years, scientists of the U.S. Geological Survey have participated in a number of scientific drilling studies of active and fossil geothermal systems in California, Colorado, Hawaii, New Mexico, and elsewhere (Appendix 3). These multidisciplinary investigations, supported by several Federal agencies, were and are expressly designed to obtain maximum scientific information about the crustal rocks penetrated.

$\dagger \quad$ Building on this linkage, in January 1994, the Geothermal Investigations Program and the Volcano Hazards Program were merged into the newly defined Volcano Hazards and Geothermal Studies Program. See U.S. Geological Survey Circular 1073 (Living with Volcanoes) for information about the Volcano Hazards Program. 


\section{Geothermal Energy and Environmental Impact}

s with other types of energy resources, geothermal energy should be developed using methods
that minimize environmental impacts. The U.S. Geological Survey is involved in studies of such issues, through its research on hydrothermal processes in general and its assessment and monitoring of hydrologic and chemical changes induced by geothermal energy development in particular.

Compared with most other forms of power production, geothermal is environmentally benign. A typical geothermal plant using hot water and steam to generate electricity emits only about 1 percent of the sulfur dioxide, less than 1 percent of the nitrous oxides, and 5 percent of the carbon dioxide emitted by a coal-fired plant of equal size. Airborne emissions from a binary geothermal plant are essentially nonexistent because geothermal gases are not released into the atmosphere. The experience gained in drilling and completing wells in a variety of geothermal environments, combined with regulatory conditions imposed by the permitting agencies, serves to minimize the risks of accidental releases of geothermal fluids.

Land areas required for geothermal developments involving powerplants and wells vary with the local reservoir conditions and the desired power outputs. A well field to support a 100 megawatt geothermal development (for generating electricity) might require about 200 to 2,000 hectares. However, while supporting the powerplant, this land still can be used for other purposes, for example livestock grazing, once the powerplant and associated piping from wells are completed. Land-area requirements, visual and noise impacts of powerplants and well fields, and risks of production-related accidents must be adequately addressed during the development phase of geothermal projects. In some areas, the cultural and (or) religious significance of areas of land having geothermal potential must be addressed before considering geothermal development.

Although geothermal energy is sometimes referred to as a renewable energy resource, this term is somewhat misleading because the available hot water, steam, and heat in any given hydrothermal system can be withdrawn faster than they are replenished naturally. It is more accurate to consider geothermal energy as a sustainable resource, one whose usefulness can be prolonged or sustained by optimum production strategy and methods. Indeed, the concept of sustainable - versus renewable-production of geothermal resources is the current focus of 


\section{Geothermal Energy is Cleaner than Conventional Energy Sources}

Coal and fossil-fuel hy drocarbons are the principal sources of energy for the United States. Together they account for about 95 percent of all US energy consumption Combustion of

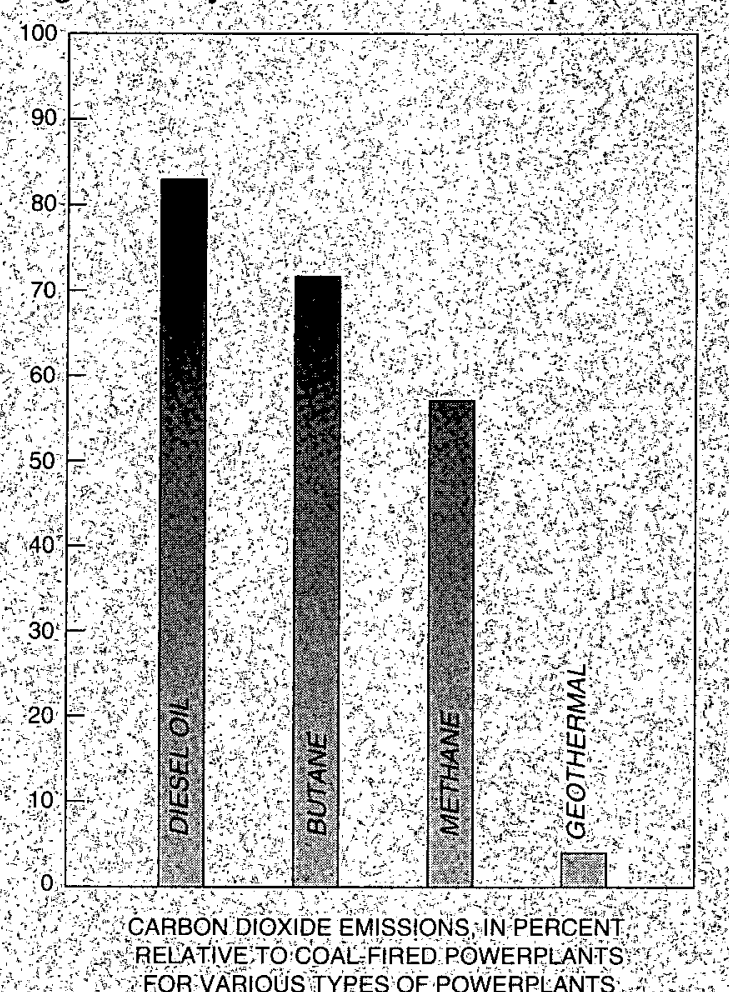

bituminous coal emits about 55 metric tons of carbon dioxide per day for every megawatt of electricity produced and even the relatively clean burning hydrocarbon, methane, releases more than 3 tons per dây for every megawatt produced In contrast, geothermally driven powerplants are much cleaner, releasing no more than 7 percent - and even as low as 0.3 percent of the carbon dioxide emitted by a methane-burning powerplant $\mathrm{A}$ similarly large contrast between geothermal and conventional fossil fuels exists for the emission of sulfurous gases.

Without dispute geothermal is a clean source of electrical energy Moreover, once on line generating electicity, geothermal powerplants are not only less polluting but also are remarkably reliable On average, geothermal powerplants are taken off line only about 5 percent of the time

Carbon dioxide is a greenhouse gas, whose ncreasing abundance in the Earth satmosphere may cause global warming. The scientific community has reached no consensus but whether or not long term global warming is occurring, data clearly show that the concentration of carbon:

Amount of carbon diox ide in the atmosphere in parts per million by volume, from 1740 to 1990. The se data were gathered at Mauna Loa Observatory on the Island of Hawait: dioxide in the atmosphere began to increase measurably with world industrialization and rapid population growth; the rate of increase has accelerated greatly during the past 50 years Combustion of fossil fuels is a major contributor to this buildup of earbon dioxide in the atmo sphere As scientists sort through the accumulating data and work to improve computer models that forecast long-term climate trends, using geothermal energy in place of fossilfuel resources provides an environmentally wise energy option.

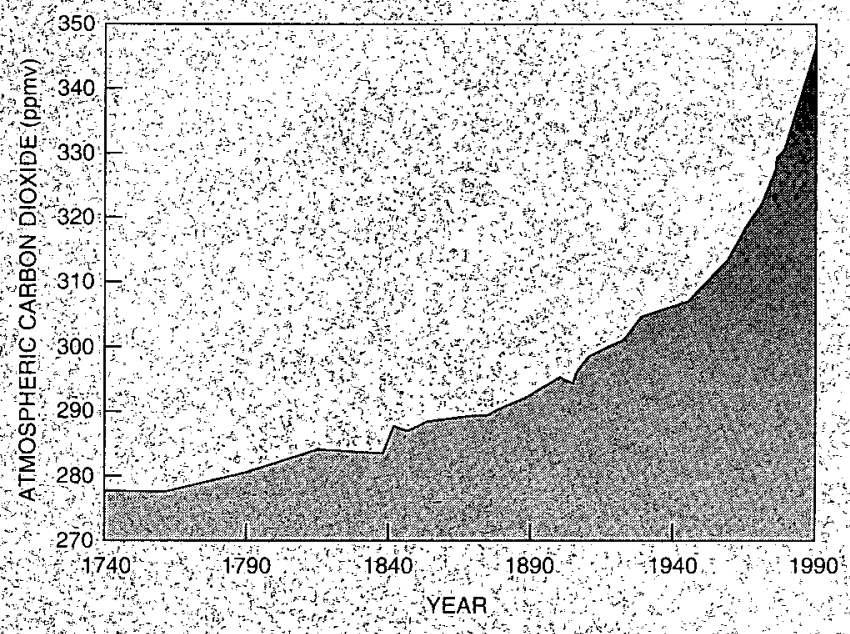




\section{Geothermal Development in Hawail Continuing Debate}

Mapshowing the five volcaños (triangles

denote summits) that make up the Island of

Hawaib riftzones

initial eruption site

for currently active

PuiOo eruption, and

the development area

for proposed Hawaii

it Geothermal Project

ond
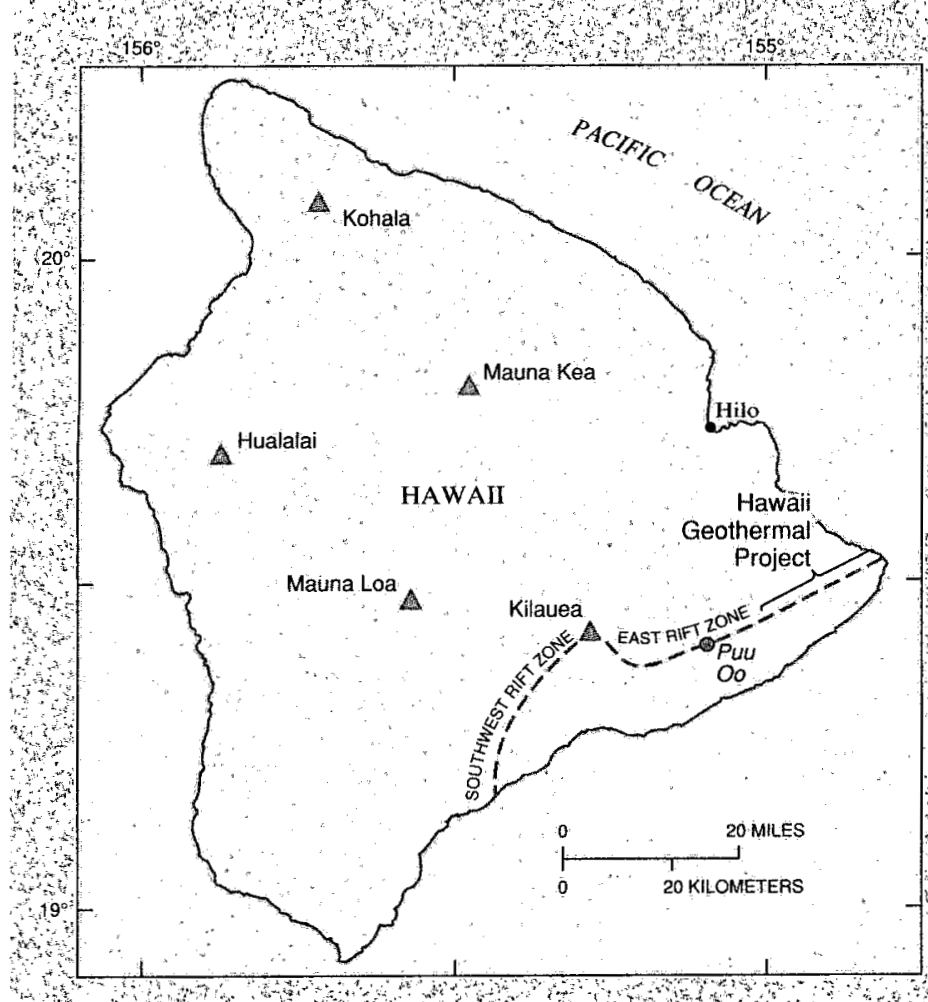

Thoúgh environmentally benign compared to conventional means of generating electricity geothermal-energy projects can nonethelés raise concens when located in areas that are either ecologically sensitive or culturally and or) religiously significant Some of the most promising land for geothermal potential is associated with active volcanoes, hot springs, boiling mud pots and geysers Such landscapes are commonly considered to have religious significance; and they are often the focal points of national parks. Concerns about preserving such areas as well as technical-development issues are at the core of the continuing debate over the desirability of harnessing geothermal energy in Hawai

The Hawail Geothermal Project, a cooperative effort between the Stâte of Hawail and the US Department of Energy (DOE) has the goal of reduc ing dependence on petroleum by developing geother mal electric power from heat sources beneath Kilauea an active volcano on the Island of Hawail Much of this electricity would be sent to the more densely populated islands of Mauiand oahu via cross island and underwater cable The project has been underway since the middle 1970 's and includes four phases Phase one nvolves drilling a production well and building a small demonstration powerplant, and this has been completed The second phase is to evaluaté the feasibility of transporting electrical power to other islands via cable and the necessary research has been completed The third phase, stillin progress entails verification and characterization of a substantial geothermal resource through drilling of scientific and commercial exploration wells The final phase nucludes both the construction of as many as 20 powerplants supplied by about 200 to 250 geothermal wells, in addition to the installation of the transmission cables to Maui and Oahu The production target is 500 megawatts of electricity

intensive studies by scientists and other specialists. Major questions being addressed are: How many hundreds or thousands of years are required to replenish a hydrothermal system? What is the best method for replenishing and sustaining a system to increase its longevity?

In practice, choices must always be made between maximizing the rate of fluid withdrawal (energy production) for a short period of time versus sustaining a lower rate for a longer period of time. For example, a recent decline in steam pressure in wells at The Geysers, California, is a result of too-rapid development of this field during the 1980's. Nonetheless, it is anticipated that production from The Geysers at the current rate of about 1,000 megawatts electric can be sustained for decades to come. Incremental development of a hydrothermal system, coupled with monitoring 
The Hawail Geothermal Project and associated activities have become intensely controversial on the Island of Hawain because of environmental; economic, Social, and religious concerns A a result, the $U . S$ Bistrict Court in Honolulu enjoined participation by all Federalagencies until an Environmental Impact Statement is completed. This statement will address potential environmental mpacts and altematives to geothermal development The DOEhas conductedmeetings to obtain public input about specific issues of concem and has sought input from other Federal agences on various technical issues. Five principal areas of concern have been identified for study by the US Geological Survey and other agencies land use, air quality water resources geologic hazards, and cable safety

Land Use Study the effects of disposal of solid and liquid waste such as drilling mud, sludge, and sanitary wastes on surface waters and hhallow ground-water aquifers

Air Quality: Define the existing air quality of potentially affected areas and stimate the mpacts to ambient air quality from controlled and uncontrolled emissions of hydrogen sulfide and other gaseous and particulate emissions from construction and operation of powerplants and wells.

Water Resources. Identify existing surface-water and ground-water resources and evaluate impacts of development to the quantity and water quality of these resources.

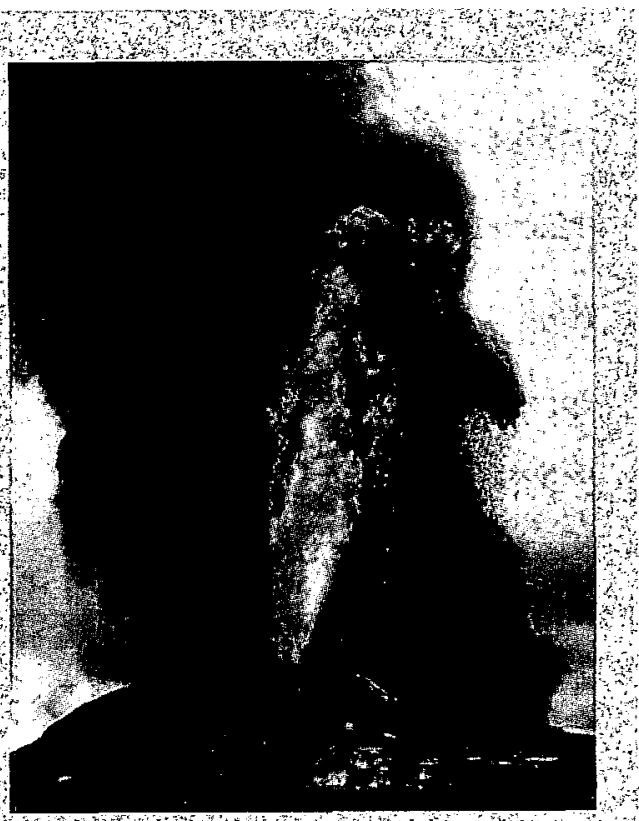

Lavafountaining in September of 1984 from Puu Oovent of Kilauea one of the five volcanoes that make up the Island of Hawail Photograph by Christina Heliker

Geologic Hazards. Evaluate the potential for induced subsidence and seismicity as aresult of fluid withdrawal and injection. Aso evaluate the likelihood that well fields, powerplants and transmission lines will be impacted by lavaflows and naturally occurring earthquakes during the lifetime of the project.

Cable Safety Evaluate the danger to the undersea cable from submarine rock slides earth quâkes, and undersea eruptions

As these studies are being carred out for the Hawail Geothermal Project a privately financed 25-megawatt (electric) powerplant and associated production and njection wells havebeen placed in operation in the lower east ift zone of Kilauea Although separate from the developments envisioned for the Hawail Geothermal Project the existing 25 -megawatt development demonstrates the commercial viability of geothermal resources in this region

for possible production-induced hydrologic and chemical changes, is the best way to determine the optimum rate of production for maximizing the longevity of a hydrothermal system.

Another important issue is the disposal of cooled geothermal water left after heat extraction or steam separation during the energy-production cycle. In the earliest geothermal developments, such "waste" water was disposed of in surface ponds or rivers. Now, in almost every geothermal development this water is injected through wells back into the subsurface. This now common practice not only minimizes the chance of contaminating surface waters, but it also provides replenishing water to help sustain a hydrothermal system, thereby increasing the total amount of heat that can be extracted over its productive life. 


\section{Yellowstone National Park - Threatened by}

Nearby Geothermal Development?

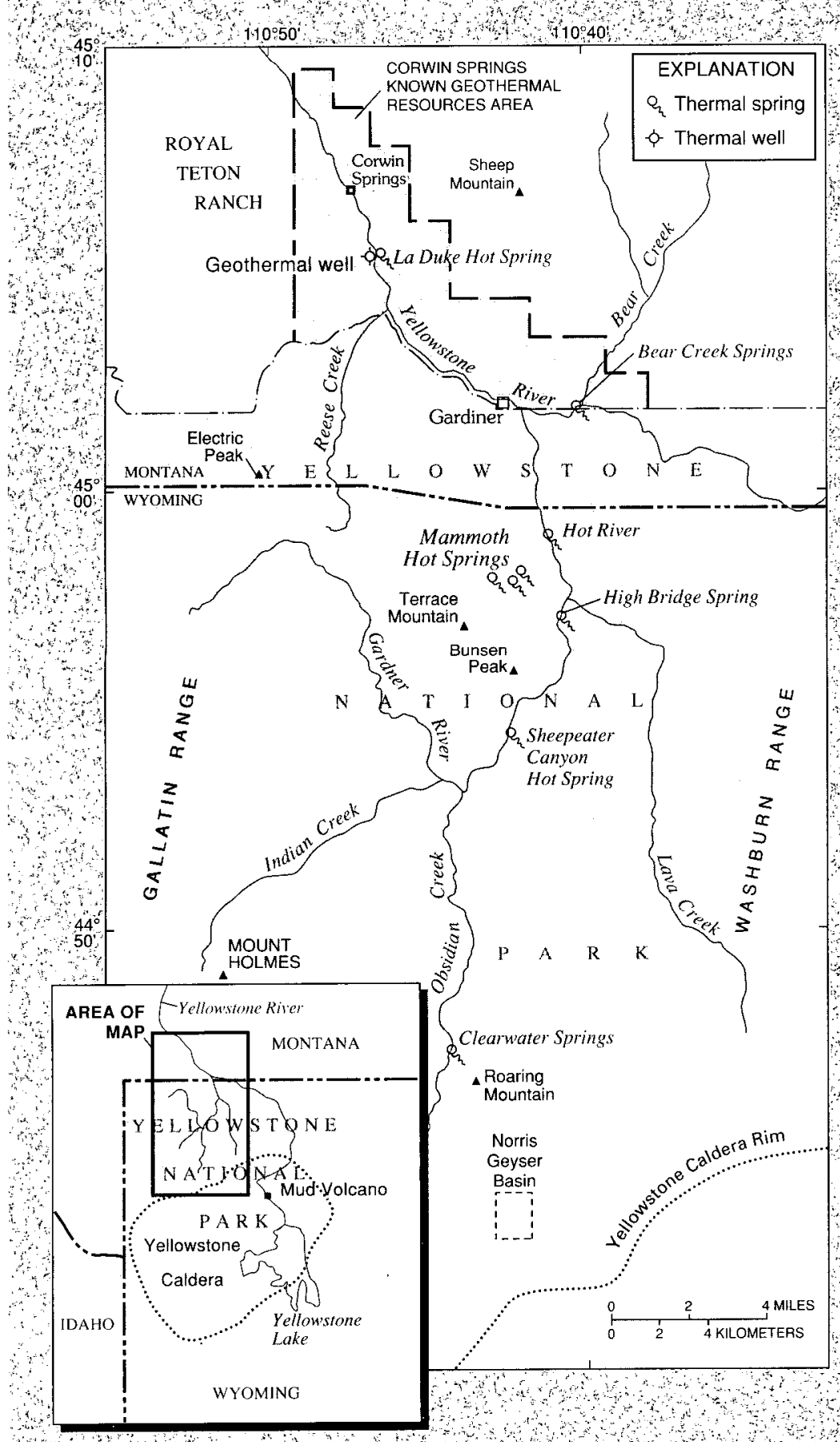

Several national parks include toot springs, geysers and other spectacular evidence of the Earth's geothermal energy: indeed, some parks were created largely because of such features For example, Yellowstone National Park the Nation's first contains the world's most varied and abundant themal features, including a proximately 10,000 geysers and hot springs

Public Law 100443 , passed by Congress in 1988 , requires the Secretary of Interior to protect the geothermal features of Yellowstone and other national paks from adverse effects of geothermal development on adjacent Federal lands. This legislátion also mandates the U.S Geological Survey, in consultation with the National Park Service, to study impacts on park geother mal features from present and potential gethermal development in adjacent areas. Specifically, the study addresses public concern over the possible effects on Yellowstone's geothermal features from production at a geothermal well about 3 kilometers north of the park boundary, in the Corwin Springs Known Geothermal Resources Area (KGRA) When this well was used 19.1986 to produce warm water a simultaneous reduction in flow occurted at La Duke Hot Spring, outside the park but directly across the Yellowstone River The nearest thermal springs inside the park are at Mammoth Hot Springs, some 14 kilometers

Map showing Yellowstone National Park, adjacent Corwin Springs Known Geothermal Resources Area principal hot springs, and a gether mal well drilled near La Duke Hot Spring. to the southeast, and a concern arose that the se could also be impacted

A U.S. Geological Survey study conducted from 1989 to 1991 concluded that separate subsurface hydrologic systems supply Mammoth Hot Springs and La Duke Hot Spring in their natural tate, but that these systems might become connected if large-scale geothermal development occurred near La Duke Hot Spring or elsewhere within the Corwin Springs KGR A.The study also concluded that if gethermal development is limited to use of the natural flow of La 
In areas with natural surface thermal features, such as hot springs and steam vents, subsurface depletion of geothermal fluids by production wells can change the rate of flow and vigor of these features, which may also be scenic and recreational attractions. Concern over such possible changes caused by commercial development has prompted legislation requiring various Federal agencies, including the U.S. Geological Survey, to try to forecast the effects of nearby geothermal development on thermal features in such national parks as Yellowstone and Lassen Volcanic. Experience suggests that adverse effects can be minimized by proper siting of injection and production wells to maintain reservoir-fluid pressure at near pre-production levels. A program of continuous monitoring of hot-spring behavior and subsurface reservoir conditions is required to identify potential problems early enough to allow timely mitigation measures.

With proper design, monitoring, and regulation, geothermal systems can generally be developed with long-term output and acceptable environmental impacts. The collection and interpretation of information on pre- and post-development conditions and changes are necessary to adequately address environmental issues. Accordingly, a principal activity of the Geothermal Investigations Program is hydrologic monitoring, which can provide early warnings of potential negative environmental effects from geothermal development, especially in areas adjacent to national parks. Such studies are being done at Long Valley Caldera and Lassen Volcanic National Park in California, at Yellowstone National Park in Wyoming, and may be desirable at Crater Lake National Park in Oregon. 


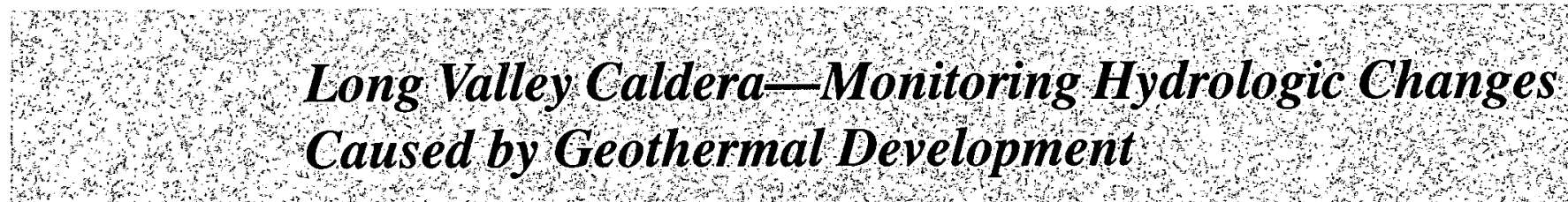

A geothermal feature at the Earth's surface has a natural life cycle bith, maturation, and eventually death, the geologic record contains many fos fil geothermal systems. The life cycle of a hot spring is generálly very long lasting centures to millennia compared to the human life cycle. However rapd geothermal change can be caused not only by powerful geologic events such as earthquakes and landslides but al so by human intervention.

Hot water produced through geothermal wells will mevitably perturb the natural subsurface conditions of a hydrothermal system At the surface a geothermal feature s response to such effects from nearby geothermal development may range from no measurable change to drying up or possibly to increased vigor. There are social and politicalireasons to avoid any human

Map of Long Valley Caldera in east-central California showing locations of geothermal powerplants hö springs and observation wells. The hot springs tand wells are being monitored by the $U . S$ Geological Survey to detect hydrologic changes that may result from geothermal development:

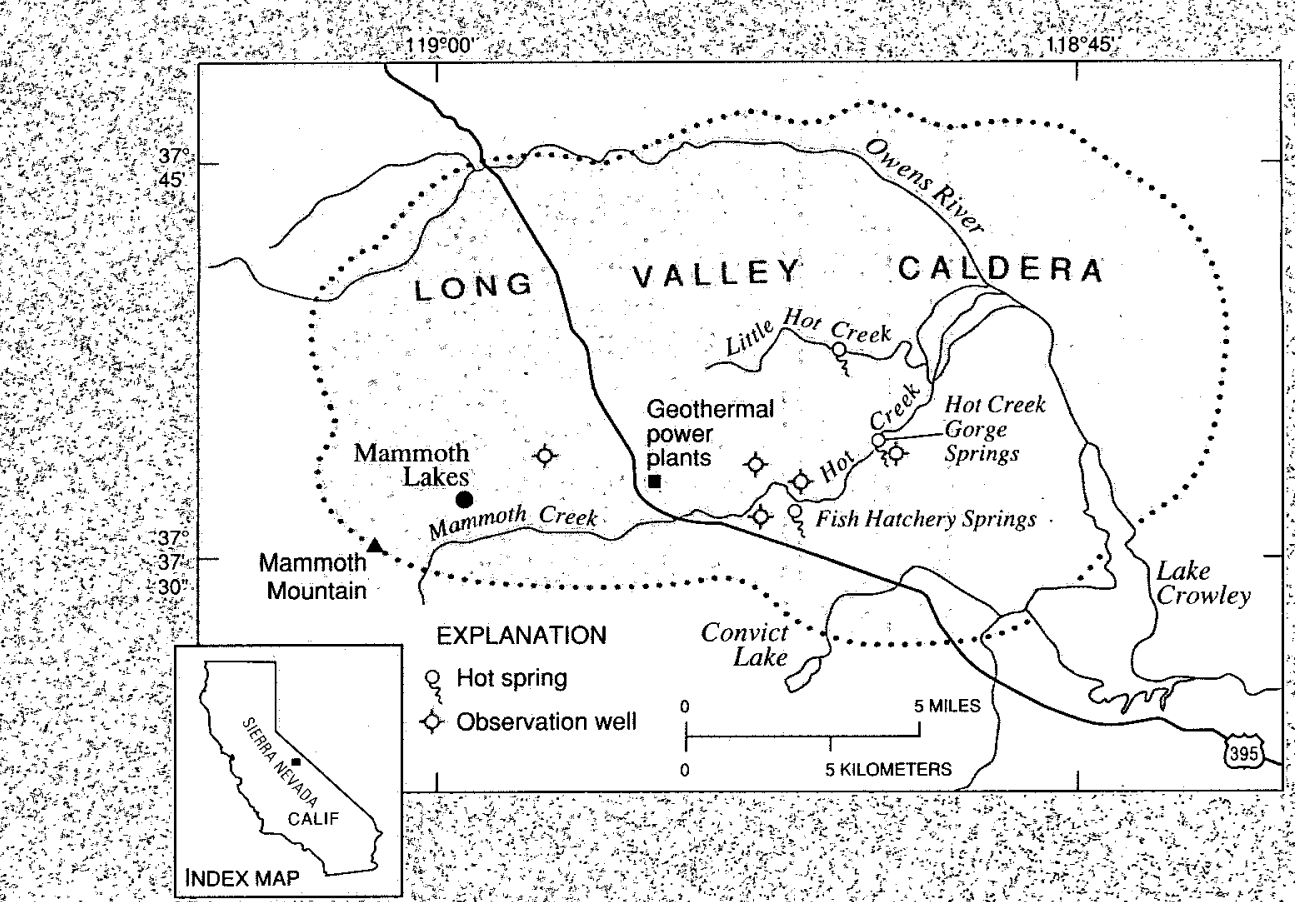

induced change to the natural condition, and considerable research is aimed at doing so through controlled and monitored development Scientists can monitor subsuiface hy drothermal conditions, enabling the early recognition of any human induced change and the initiation of any needed mitigating measures Such hydrologic monitoring is currently being conducted at the Long Valley Caldera in east central Califomia.

Active hot springs are common in the Long Válle y Caldera region, volcanically active as recently as about 500 years ago. Following surface exploration and test drilling during the $1970^{\circ}$ sand early $1980^{\circ} \mathrm{s}$ a geothermal binary powerplant was constructed there in 1985 Two more binary powerplants came on line in 1990 , and additional geothermal exploration and development are ongoing Moreo er, the ski-resort town of Mammoth Lakes, within the caldera, has drilled several wells to evaluate producing geothermal fluids for direct use applications 
These geothermal energy de velopments combined with a growing need for cool ground water for municipal consumption highlight the greatly increased demands on the region s hydrologic resources and the need to balance the benefits of geothermal and other ground-water develop ment with the long-standing recreational activities of the area To address such issues, the Long Valley Hydrologic Advisory Committee (GVAC) was formed in 1987 , it is composed of members from private companies and government agencies, including the US. Geological Survey, a nonvoting member.

A major purpose of the LVHAC is to oversee hydrologic monitoring focused on early detection of changes in hot springs and streams that might be induced by geothermal and other ground-water developments In addition, the committee advises the permitting agencies of significant hydrologic changes and may recommend mitigation actions as appropriate to minimize or perhaps reverse such changes. The advice and suggestions of the LVHAC are not legally binding but they form the basis for regulatory decisions by permitting agencies such as the US. Forest Service, the Bureau of Land Management and the Mono County government The US. Geological Survey is responsible for collecting and compiling baseline hydrologic data of the monitorng programand for furnishing this information to the committe on a quarterly basis

Thermal springs are present in the central and easten parts of Long valley Caldera Most important from an environmental-protection standpoint are the springs in Hot Creek Gorge and at the Hot Creek State Eish Hatchery Monitoring at these and other sprngs includes continuous or periodic measurements of rate of wáter flow temperature, and chemical composition, numer ous wells in the region also allow the monitoring of pressure (or water level) temperature, and water che mistry Similar monitoring data from the production and injection wells of the geothermal development area are collected and compiled by the powerplant operator

The formation of the $\mathrm{LVHAC}$ facilitated approval of the current geothermal develop ments in the Long Valley Calderatby providing a forum for discuission of the key issues and concerns relative to potential adverse effects on themal springs from pumping and injecting geothermal fluid An important function of the committee is to ensure that economically reasonable, environmentally sound compromises can be nade after consideration of the different concerns of various interest groups The US Geological Survey' S role in this effort is to nterpret the causes of the identified hydrologic changes and to recommend remedial measures to mitigate possible adverse effects.

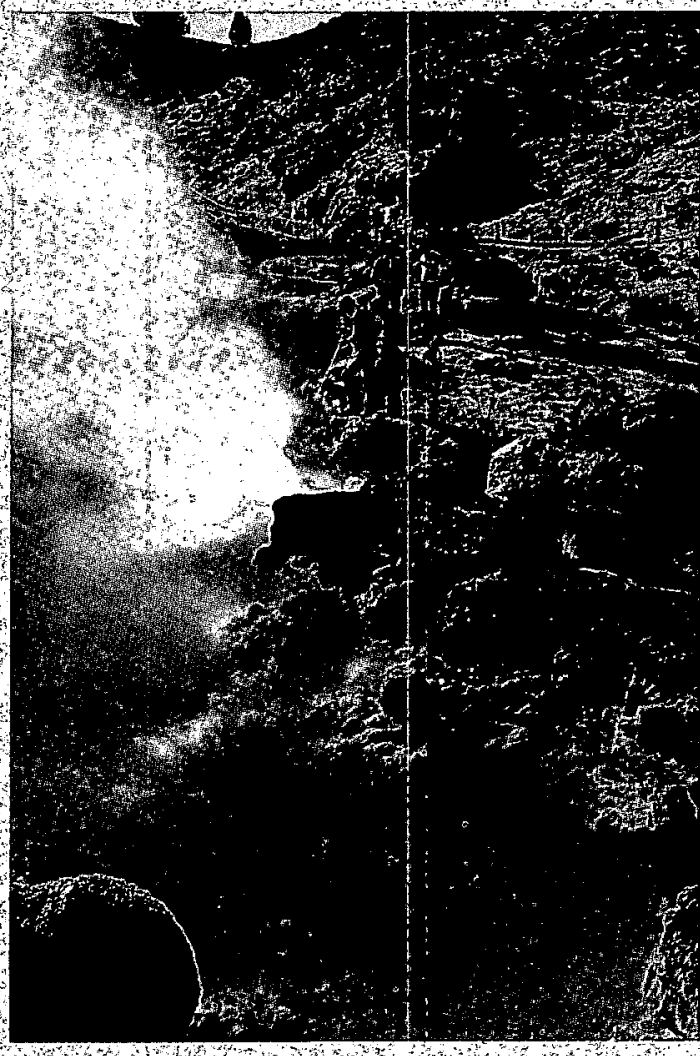

Boiling hot springs in Hot Creek Gorge lo cated within Long Val ley Caldera, approximatel 1 is kilometers east of the tow of Mammoth Lakes in east central California 


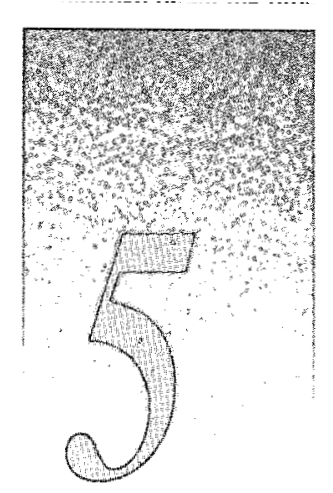

\section{A Look Toward the Future}

Total capacities of electrical and nonelectrical geothermal developments in the United States as of 1990.
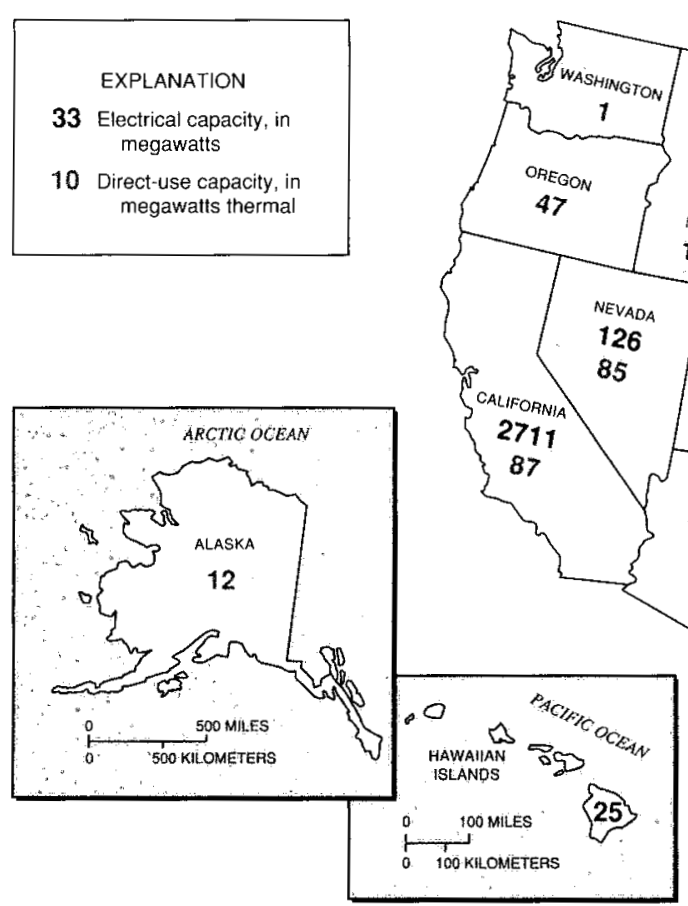
For example, considerable promise may exist for the discovery of moderate- to high-temperature geothermal resources within the Basin and Range physiographic province, the Cascade Range, the Salton Trough, the Rio Grande Rift, and the northern part of the Great Plains physiographic province. The Basin and Range, in particular, is characterized by geologic conditions favorable for the occurrence of hydrothermal systems. Presently-known high-temperature systems associated with young volcanic activity are concentrated along the margins of this physiographic province: along the western margin (in California, Nevada, and Arizona), and along the eastern margin (in Idaho and Utah). Other hydrothermal systems, not obviously expressed at the surface, could be present within the interior parts of the province. To date, only a few such systems have been developed. Discovery of additional geothermal systems within the Basin and Range province would be enhanced by new geophysical studies and scientific drilling at selected locations. Such work might be efficiently accomplished under the type of government-industry-coupled program that successfully produced a series of state geothermal-resource assessments during the 1970's and 1980's.

Another region that merits continued study is the Cascade Range in Washington, Oregon, and northern California. Hydrothermal systems have been identified and partially explored at

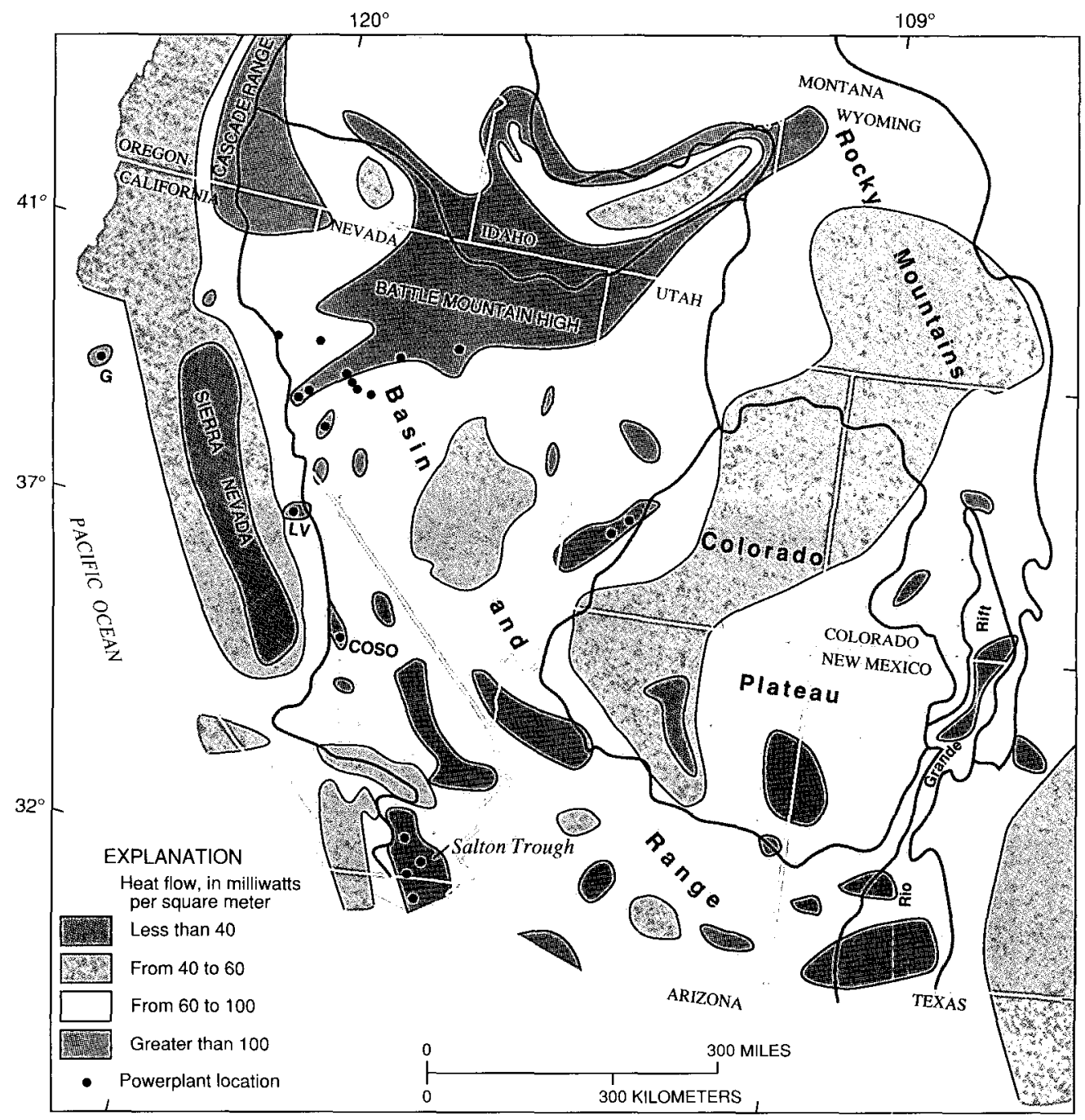

Map of physiographic provinces, other geographic features of geothermal interest, and heat flow in the southwestern United States. G, The Geysers; LV, Long Valley. 
Medicine Lake Highlands and Lassen Volcanic National Park in California, Newberry Crater and Crater Lake National Park in Oregon, and at Mount Meager in British Columbia, Canada. Ongoing research by the U.S. Geological Survey is focused on deciphering the evolution of the Cascade volcanoes and interpreting geophysical information in terms of models of fluid and heat flow on a regional scale within the Cascade Range. To be most useful, such studies should be complemented by scientific drilling of selected geothermal target areas. The results of this work also form the basis for a cooperative project between the U.S. Geological Survey and the Geological Survey of Japan, to compare and contrast geothermal aspects of two broadly similar volcanic chains in the two countries.

Principal volcanoes, geologically young volcanic rocks (yellow areas), and hot springs in the Cascade Range, Pacific Northwest.

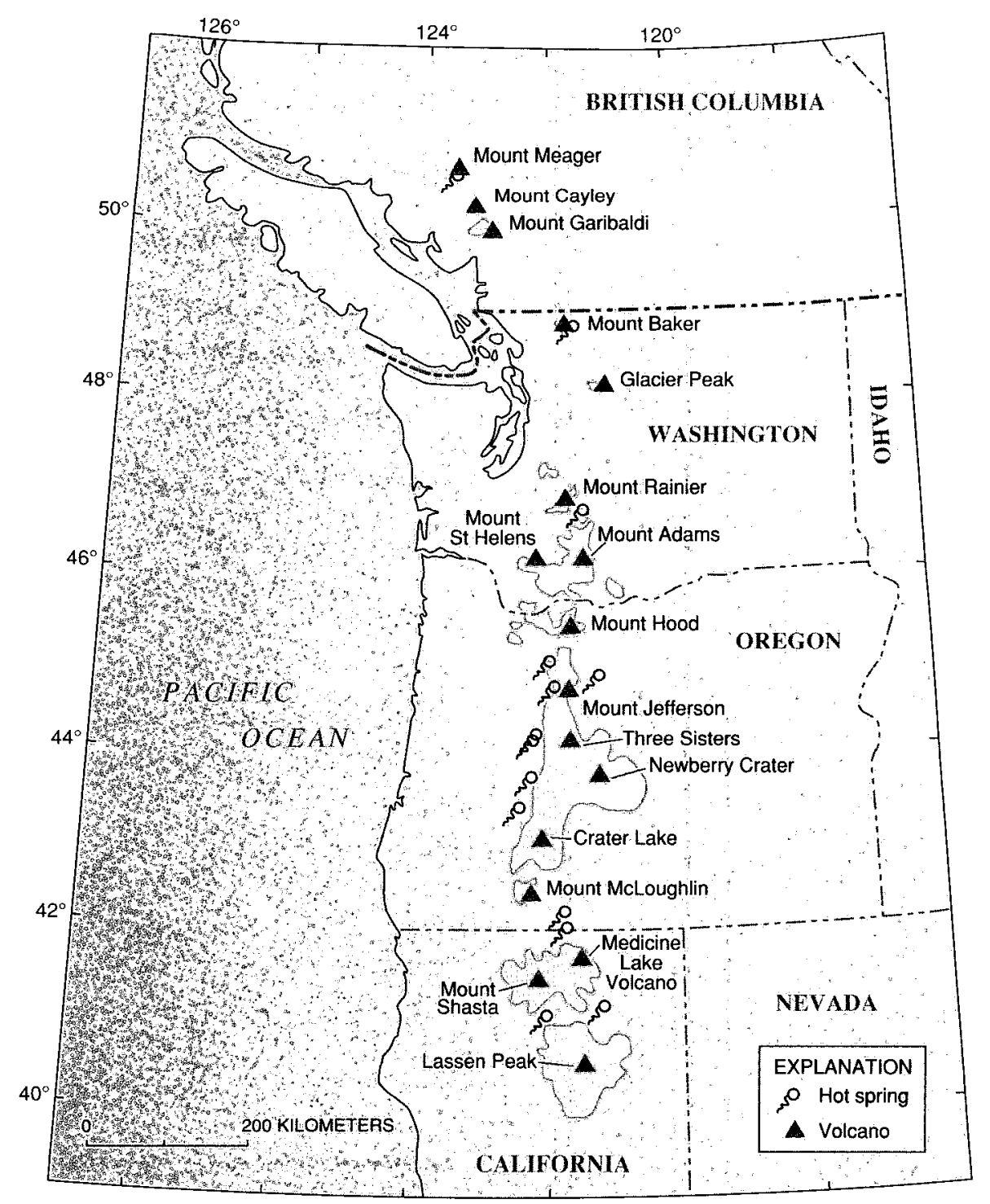




\section{SEARCHING FOR DEEPER HYDROTHERMAL SYSTEMS}

Because all hydrothermal systems with surface expression have been explored to some degree, an important line of research is to develop techniques and strategies to discover hidden systems at great depths. This research entails deep drilling. Given the relatively high risk of such ventures, this work seems appropriate principally for the public sector, perhaps on a costsharing basis with the private sector.

Additional research into the origins of vapor-dominated systems is also needed, and target areas should include The Geysers, California, and Larderello, Italy-two areas where this uncommon but highly sought after geothermal environment exists. Current understanding of how these exceptionally high grade steam systems originate and persist over geologic time is poor, despite the fact that these are the electrical-grade resource most easily developed. In addition, recent drilling at The Geysers and Larderello has revealed high-pressure, hot-water regimes adjacent to the developed steam zones. This exciting discovery invites an entirely new thrust for the study of deeper, higher pressure underpinnings (so-called root zones) of hydrothermal systems. Overpressured, high-temperature hydrothermal environments may be common near magma bodies, within the temperature range where the physical behavior of rocks changes from brittle (capable of fracture) to ductile (capable of flow). Research into the deeper parts of magmatic hydrothermal systems, in tandem with advances in the technologies for drilling deeper and at higher temperatures, could lead to the identification of substantially more high-grade geothermal resources for the United States and the world.

\section{DEVELOPING RESERVOIR-ENHANCEMENT TECHNOLOGY}

Many rocks at cost-effective drilling depths are hot enough to provide large amounts of potentially usable thermal energy, but they are not sufficiently permeable to form a natural hydrothermal reservoir. In such cases, thermal energy can be recovered using techniques for creating permeability through hydraulic fracturing. Potentially attractive targets for reservoir enhancement include all currently developed hydrothermal systems and others that have been considered uneconomic because of low permeability.

Tapping into the vast store of thermal energy in hot, low-permeability rock may well hold the key to unlocking much more of the Earth's abundant natural heat to benefit humankind in the 21 st century and beyond. First, however, further testing of the emerging hot-dry-rock and other reservoir-enhancement technologies must prove the commercial viability of such heat extraction. The geothermal studies of the U.S. Geological Survey could provide a solid scientific foundation for a large-scale national project-in collaboration with industry, universities, and national laboratories-to test such commercial viability.

\footnotetext{
Because all hydrothermal systems with surface expression have been explored to some degree, an important line of research is to develop techniques and strategies to discover hidden systems at great depths.
} 


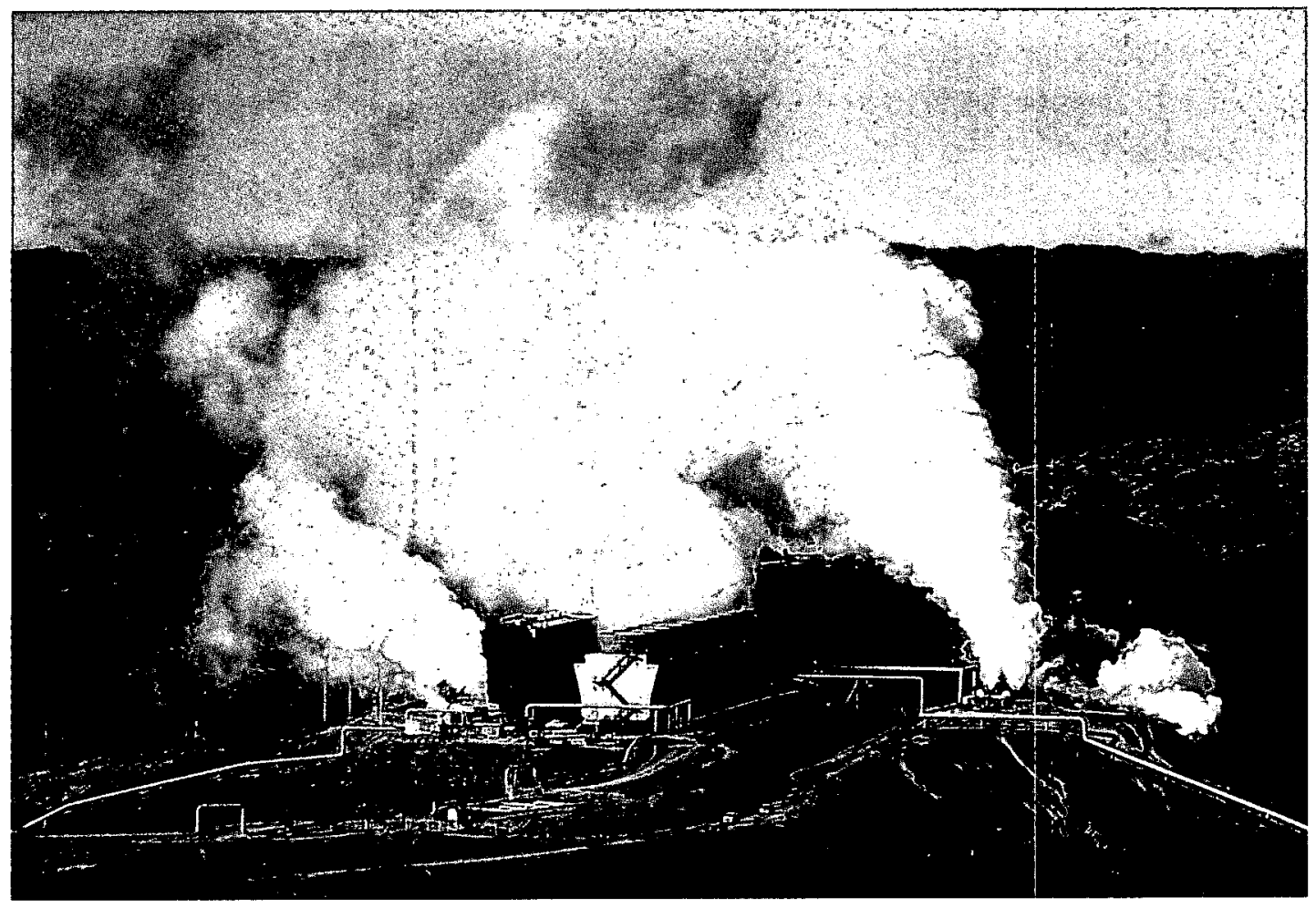

Geothermal powerplant at The Geysers near Santa Rosa, California. Photograph courtesy of Pacific Gas and Electric Company. 


\section{Suggested Additional Reading}

Anderson, D.L., Tanimoto, T., and Zhang, Y-S., 1992, Plate tectonics and hot spots: The third dimension: Science, v. 256, p. 1645-1651.

Bulletin of the Geo-Heat Center, Oregon Institute of Technology, Klamath Falls, Oregon, v. 14, no. 1, 1992.

Bulletin of the Geothermal Resources Council: v. 17, nos. 5,7,9, 1988; v. 19, nos. 1,2,3,7,10, 1990 ; v. 20 , nos. 3,5,6, 1991; v. 21, nos. 2,5, 1992.

Garside, L.J., and Hess, R.H., 1994, Nevada geothermal resource use-1993 update: Geothermal Resources Council Bulletin, v. 23, no. 2, p. 47-54.

Lienau, P.J., and Lunis, B.C., eds., 1991, Geothermal Direct Use Engineering and Design Handbook: Geo-Heat Center, Klamath Falls, Oregon, 445 p.

Kenkeremath, D.C., Blackett, R.E., Satrape, J.V., and Beeland, G.V., 1985, The current status of geothermal direct use development in the United States: Proceedings of the 1985 International Symposium on Geothermal Energy, Geothermal Resources Council, Davis, California, p. 223-236.

Lachenbruch, A.H., and Sass, J.H, 1977, Heat flow in the United States and the thermal regime of the crust, in Heacock, J.G., ed., The Earth's Crust: American Geophysical Union Geophysical Monograph 20, p. 626-675.

Lund, J.W., Lienau, P.J., and Culver, G., 1990, The current status of geothermal direct use development in the United States-Update: 1985-1990: Transactions of the Geothermal Resources Council, v. 14, Part 1, p. 277-291.

McCabe, P.J., Gautier, D.L., Lewan, M.D., and Turner, Christine, 1993, The Future of Energy Gases: U.S. Geological Survey Circular 1115, 58 p.

Muffler, L.J.P., 1977, Technical analysis of geothermal resources, in Sato, Sho, and Crocker, T.D., eds., Property rights to geothermal resources (part one): Ecology Law Quarterly, v. 6, no. 2, p. 253-270.

Muffler, L.J.P., ed., 1979, Assessment of geothermal resources of the United States-1978: U.S. Geological Survey Circular 790, 163 p.

Muffler, L.J.P., 1981, Geothermal resource assessment: in Rybach, L. and Muffler, L.J.P., eds., Geothermal systems: Principals and case histories, New York, John Wiley, 359 p.

Pollack, H.N., Hurter, S.J., and Johnson, J.R., 1990, The new global heat-flow data compilation: Eos, Transactions of the American Geophysical Union, v. 71, p. 1604.

Rannels, J.E., and McLarty, L., 1990, Geothermal power generation in the United States, 1985 through 1989: Transactions of the Geothermal Resources Council, v. 14, Part 1, p. 293-304.

Reed, M.J., ed., 1983, Assessment of low-temperature geothermal resources of the United States-1982: U.S. Geological Survey Circular 892, 73 p. 
Sass, J.H., Lachenbruch, A.H., Galanis, S.P., Morgan, P., Priest, S.S., Moses, T.H., Jr, and Munroe, R.J., in press, Thermal regime of the southern basin and range province: I. Heat-flow data from Arizona and the Mojave Desert of California and Nevada: Journal of Geophysical Research.

Smith, R.L., Shaw, H.R., Luedke, R.G., and Russell, S.L., 1978, Comprehensive tables giving physical data and thermal energy estimates for young igneous systems of the United States: U.S. Geological Survey Open-File Report 78-925, 15 p.

Sorey, M.L., editor, 1991, Effects of potential geothermal development in the Corwin Springs Known Geothermal Resources Area, Montana, on the thermal features of Yellowstone National Park: U.S. Geological Survey Water-Resources Investigations Report 91-4052, 205 p.

Sorey, M.L., and Ingebritsen, S.E., 1984, Quantitative analysis of the hydrothermal system in Lassen Volcanic National Park and Lassen Known Geothermal Resource Area: U.S. Geological Survey Water Resources Investigations Report 84-4278, 80 p.

Sorey, M.L., Suemnicht, G.A., Sturchio, N.C., and Nordquist, G.A., 1991, New evidence on the hydrothermal system in Long Valley Caldera, California, from wells, fluid sampling, electrical geophysics, and age determinations of hot-spring deposits: Journal of Volcanology and Geothermal Research, v. 48, p. 229-263.

Tilling, R.I., Topinka, Lyn, and Swanson, D.A., 1990, Eruptions of Mount St. Helens: Past, present, and future: U.S. Geological Survey general-interest publication (revised edition), $56 \mathrm{p}$.

White, D.E., and Williams, D.L., eds., 1975, Assessment of geothermal resources of the United States-1975: U.S. Geological Survey Circular 726, 155 p.

Wohletz, K., and Heiken, G., 1992, Volcanology and geothermal energy: Berkeley, University of California Press, $432 \mathrm{p}$.

Wright, T.L., and Pierson, T.C., 1992, Living with volcanoes: The U.S. Geological Survey's Volcano Hazards Program: U.S. Geological Survey Circular 1073, 57 p. 


\section{Appendix 1. Geothermal Developments in the United States as of 1990}

\begin{tabular}{|c|c|c|c|c|}
\hline & Locality & $\begin{array}{c}\text { Electrical } \\
\text { Capacity }{ }^{1} \\
\text { MWe }\end{array}$ & $\begin{array}{c}\text { Direct-Use } \\
\text { Capacity } \\
\text { MWt }\end{array}$ & Comments $^{3}$ \\
\hline \multicolumn{5}{|l|}{ Alaska } \\
\hline & Circle Hot Springs & - & 4.1 & Space heat and swimming pool \\
\hline & Manley Hot Springs & - & 3.9 & Space heat, bath, greenhouse \\
\hline & Chena Hot Springs & - & 2.3 & Space heat, bath, greenhouse \\
\hline & Other areas & - & 1.5 & Various uses \\
\hline \multicolumn{5}{|c|}{ Arkansas } \\
\hline \multicolumn{5}{|l|}{ Arizona } \\
\hline & Safford area & - & 16.7 & Fish and other animal farming \\
\hline & Tucson & - & 2.3 & Fish and other animal farming \\
\hline \multicolumn{5}{|l|}{ California } \\
\hline & The Geysers & 1,971 & - & Dry steam plants \\
\hline & Coso & 256 & 一 & Flash plants \\
\hline & Salton Sea & 214 & - & Flash plants \\
\hline & East Mesa & 102 & _- & Binary plants \\
\hline & Heber & 92 & - & Flash and Binary \\
\hline & Long Valley Caldera & 43 & - & Binary plants \\
\hline & Honey Lake & 30 & - & Binary plants \\
\hline & Amadee Hot Springs & 3 & - & Binary plants \\
\hline & Susanville & - & 17.8 & District heating, space heat \\
\hline & San Bernadino & - & 13.7 & Sewage treatment, district heating \\
\hline & Wendell Hot Spring & - & 8.3 & Greenhouses \\
\hline & Paso Robles & - & 3.8 & Fish farming \\
\hline & Mecca & - & 2.2 & Aquaculture \\
\hline & Coachella & - & 1.8 & Greenhouses \\
\hline & Cedarville & - & 1.0 & Space heat \\
\hline & Other areas & - & 2.1 & Various uses \\
\hline \multicolumn{5}{|l|}{ Colorado } \\
\hline & Pagosa Springs & - & 14.0 & District heating, space heat \\
\hline & Glenwood Springs & - & 9.6 & Space heat, swimming pool \\
\hline & Alamosa & - & 7.7 & Space heat \\
\hline & Other areas & - & 2.1 & Various uses \\
\hline \multicolumn{5}{|l|}{ Hawaii } \\
\hline & \multicolumn{4}{|c|}{ Idaho } \\
\hline ratano & Boise & — & 57.3 & District heating, space heat \\
\hline & Buhl & - & 22.1 & Greenhouse, fish farming \\
\hline & Warm Springs Creek & - & 20.7 & Greenhouse \\
\hline & Ketchum & - & 12.4 & Space heat \\
\hline & White Arrow & - & 11.9 & Greenhouse, fish farming \\
\hline & Cassia County & - & 10.7 & Greenhouse \\
\hline & Cookes Hot Spring & - & 7.1 & Greenhouse \\
\hline & Twin Falls County & - & 16.6 & Space heat, greenhouses \\
\hline & Garden Valley & - & 2.8 & Greenhouse \\
\hline & Boise area & - & 2.6 & Greenhouse \\
\hline & Caldwell & - & 1.8 & Space heat \\
\hline & Other areas & - & 5.5 & Space heat, greenhouses \\
\hline \multicolumn{5}{|l|}{ Montana } \\
\hline & White Sulfur Springs & - & 4.6 & Space heat, bath \\
\hline & Other areas & - & 5.1 & Space heat, greenhouses \\
\hline \multicolumn{5}{|l|}{ Nevada } \\
\hline & Dixie Valley & 50 & - & Flash plants \\
\hline & Steamboat Springs & 18 & - & Flash and binary plants \\
\hline & Soda Lake & 16 & - & Binary plants \\
\hline
\end{tabular}


[MW, megawatts; e, electrical; t, thermal]

\begin{tabular}{|c|c|c|c|c|}
\hline & Locality & $\begin{array}{c}\text { Electrical } \\
\text { Capacity }^{1} \\
\text { MWe }\end{array}$ & $\begin{array}{c}\text { Direct-Use } \\
\text { Capacity }^{2} \\
\text { MWt }\end{array}$ & Comments $^{3}$ \\
\hline \multicolumn{5}{|c|}{ Nevada (cont.) } \\
\hline & Beowawe & 15 & - & Flash plants \\
\hline & Stillwater & 13 & - & Binary plants \\
\hline & Desert Peak & 9 & - & Flash plants \\
\hline & San Emidio Desert & 3 & - & Binary plants \\
\hline & Wabuska & 2 & 11.0 & Binary plants, crop-drying \\
\hline & Bradys Hot Spring & - & 18.3 & Food drying \\
\hline & Round Mountain Gold & - & 14.1 & Mineral leaching \\
\hline & Caliente & - & 13.3 & Space heat \\
\hline & Elko & - & 10.6 & Space heat \\
\hline & Moana & - & 6.0 & Space heat \\
\hline & Reno & - & 4.4 & Space heat \\
\hline & Warren Estates & - & 2.4 & Space heat \\
\hline & Florida Canyon & - & 1.4 & Mineral leaching \\
\hline & Other areas & - & 3.6 & Various uses \\
\hline \multicolumn{5}{|c|}{ New Mexico } \\
\hline & Animas & - & 7.9 & Greenhouses \\
\hline & Las Cruses & - & 2.8 & Space heat \\
\hline & Other areas & - & 9.1 & Various uses \\
\hline \multicolumn{5}{|l|}{ New York } \\
\hline & Auburn & - & 1.2 & Space heat \\
\hline \multicolumn{5}{|l|}{ Oregon } \\
\hline & Klamath Falls & - & $\begin{array}{l}18.8 \\
12.6\end{array}$ & $\begin{array}{l}\text { Space neat (residential) } \\
\text { District heating }\end{array}$ \\
\hline & & & 6.4 & Space heat (commercial) \\
\hline & Vale & - & 5.4 & Agribusiness \\
\hline & Other areas & - & 3.5 & Various uses \\
\hline \multicolumn{5}{|c|}{ South Dakota } \\
\hline & Phillip & - & 4.4 & District heating, greenhouse \\
\hline & Pierre & - & 2.2 & Space heat \\
\hline & Haakon County & - & 2.1 & Space heat, crop drying \\
\hline \multicolumn{5}{|l|}{ Texas } \\
\hline & Marlin & - & 1.4 & Space heat \\
\hline & Other areas & 一 & 0.6 & Space heat, bath, aquaculture \\
\hline \multicolumn{5}{|l|}{ Utah } \\
\hline & Cove Fort & 13 & - & Flash and binary \\
\hline & Roosevelt Hot Spring & 20 & - & Flash plant \\
\hline & Salt Lake County & - & 11.8 & Space heat, greenhouse \\
\hline & Other areas & - & 0.9 & Greenhouses, baths \\
\hline \multicolumn{5}{|c|}{ Washington } \\
\hline & Several areas & - & 1.0 & Space heat \\
\hline \multirow[t]{4}{*}{ Wyoming } & & & & \\
\hline & Thermopolis & - & 9.0 & Space heat, greenhouse \\
\hline & Lander & - & 2.2 & Greenhouse, fish farming \\
\hline & Other areas & - & 0.4 & Various uses \\
\hline
\end{tabular}

${ }^{\mathrm{i}}$ Rated output of all powerplants in megawatts electric (MWe); dash indicates no development.

${ }^{2}$ Thermal capacity in megawatts thermal (MWt), calculated from maximum flow rate and water temperature data where available, or from annual energy use divided by load factors of 0.1-0 5 for space heating and district heating projects and 0.4-0.8 for other uses. Only those localities with thermal capacities greater than $1 \mathrm{MWt}$ are listed separately. Dash indicates no development.

${ }^{3}$ Dry steam plant signifies that wells produce dry steam that is piped directly to the powerplant; flash plant signifies that wells produce a mixture of steam and water that must be separated before steam is piped to the powerplant; binary plant signifies that wells produce liquid water which is piped to the powerplant where heat is transferred to a binary working fluid. 
Appendix 2.

\section{Selected Principal Geothermal Studies of the U.S. Geological Survey}

The items highlighted below give a sampling of the geothermal studies of U.S. Geological Survey.

- Development and refinement of methods to determine the subsurface temperature of a hydrothermal system from the chemical composition of surface geothermal fluids collected at fumaroles and hot springs fed from that system. These methods, collectively called "chemical geothermometry," are now being used as standard exploration tools worldwide.

- Recognition that surface samples originating from vapor-dominated hydrothermal systems have a chemical signature distinctly different from surface samples originating from water-dominated systems (for example, low chlorine concentrations versus high chlorine concentrations, respectively). Such recognition provides a simple and reliable means of identifying the type of hydrothermal system, without the need for costly confirmatory drilling.

- Monitoring the chemical composition of geothermal fluids produced through wells. Early detection of significant variations in composition, which in turn reflect productioninduced changes in the conditions of the hydrothermal reservoir, makes it possible to modify production strategy and methods - at a critical early stage-to prolong reservoir productivity and to minimize potential adverse environmental impacts.

- Integrated field and laboratory studies, including the making of new geologic maps, of many young or active volcanic fields in the western United States, Alaska, and Hawaii that host most known electrical-grade hydrothermal systems. Information derived from these studies provides the basic input for calculating geothermal resources associated with each volcanic field and also is used by industry to guide exploration.

- Discovery of magma bodies by means of innovative geophysical studies, including seismic tomography.

- Preparation and publication of maps of temperature gradients in wells and heat flow for the contiguous United States; these maps define broad regions of differing geothermal potential. In addition, detailed heat-flow surveys of selected smaller areas, such as Long Valley Caldera, California, provide evidence of local concentrations of geothermal heat.

- Drilling of a 900-meter-deep research hole at Newberry Caldera, Oregon. The drilling and surface-based geologic and geophysical studies discovered a hydrothermal system of at least $260^{\circ} \mathrm{C}$-the first direct confirmation of an electrical-grade hydrothermal system in the Cascade Range region. 
- Carrying out specific resource evaluations in support of the Federal geothermal-leasing program. Such activities provide the Federal Government with the information needed to establish a fair market value for the geothermal resources on Federal lands.

- Monitoring and resource-evaluation studies at Yellowstone, Lassen, Crater Lake, and Mount Rainier National Parks to advise the Federal Government on possible adverse impacts on natural geothermal features (hot springs, fumaroles, and mud pots) that might be induced by nearby geothermal development. A similar and even more intense effort accompanies ongoing geothermal development at Long Valley Caldera, California.

- Participation in many technical-assistance missions and training courses pertinent to geothermal-resource evaluations in foreign countries, including Argentina, Costa Rica, France, Guatemala, Honduras, Iceland, Indonesia, Italy, Jordan, Korea, Mexico, Portugal (both the mainland and the Azores), and in the Caribbean region (Saint Lucia and The Dominican Republic). Such activities, typically undertaken in cooperation with the Department of State or international organizations such as the United Nations, not only help to accomplish U.S. foreign-policy objectives, but also benefit the domestic program by allowing scientists of the U.S. Geological Survey to gain valuable experience in working in diverse geothermal settings and access to information from geothermal wells otherwise unobtainable.

- Using the data obtained from above-listed and other geothermal studies, together with all other available information, the U.S. Geological Survey completed three national geothermal-resource assessments based on uniform methodology applied on a hydrothermal-system-by-hydrothermal-system basis. This methodology now is in general use both domestically and worldwide. 
Appendix 3.

\section{Scientific Drilling in Geothermal Systems}

During the past two decades, shallow- to intermediate-depth research wells have been drilled in the Imperial Valley (the Salton Sea, California, Scientific Drilling Project), at the Inyo Domes, California, in the Valles Caldera, New Mexico, and in the Cascade Range of the Pacific Northwest. In addition, reconnaissance-style drilling to determine heat flow and hydrologic characteristics was completed over much of the western United States. The U.S. Geological Survey participated in most of these multidisciplinary, multiagency projects. Current and planned drilling projects with implications for geothermal resources include the DOE's Long Valley Caldera Exploratory Well, California, the U.S. Geological Survey's Creede Caldera Project, Colorado, a corehole at Hilo, Hawaii (funded by the National Science Foundation), and multiagency projects at Katmai, Alaska, The Geysers, California, and in the western part of the Long Valley Caldera, California. Foreign drilling projects with geothermal applications include those at White Island (New Zealand), Tyrniauz (Russia), and several projects in Japan. U.S. Geological Survey personnel are involved in scientific experiments at each of these sites.

Drilling near the center of Long Valley Caldera was envisioned initially as a probe into a near-magmatic regime to test the hypothesis that molten rock was present at drillable depth, to assess the extent and composition of corrosive geothermal gases and fluids, and to test various drill-hole casing and heat-exchanger materials under natural near-magmatic conditions. However, changes in funding sources and associated priorities have shifted the focus toward exploration of the hydrothermal resource beneath the central and western parts of the caldera.

The coreholes of the Creede Caldera Project are designed to sample ancient lakebottom sediments in this 25 -million-year-old caldera. These sediments may have been the reservoir for convecting hydrothermal fluid responsible for the deposition of silver and base-metal ores in the adjacent Creede Mining District. This project is a useful counterpart to studies of active hydrothermal systems at the Salton Sea, Valles Caldera, Inyo Domes, and Long Valley Caldera. At Creede, much of the fossil magmatic/hydrothermal system has been exposed through erosion and thus is more readily accessible by drilling than are the younger and deeper active systems.

The Katmai project is one of the most complex scientific drilling experiments ever proposed, primarily because of its remote location and extreme environmental sensitivity (in a national park). The project was designed to investigate a unique geothermal setting-namely, a very young volcanic system that in 1912 produced the largest explosive eruption of the 20th century. At present, there are serious doubts that the project will go forward, based primarily on environmental concerns. If these doubts are 
resolved, the Katmai project should provide information about fundamental processes of volcanism and hydrothermal mineralization that occurred at Katmai, as well as general findings that can be applied to understanding magma-related geothermalenergy environments.

In response to the recent declines in steam production and quality, scientific drilling began in the summer of 1994 at the bottom of an existing 1,340-m-deep production well at The Geysers geothermal field to penetrate another 300 meters into its steam reservoir. This DOE-funded study - The Geysers Coring Project-will focus on comprehensive laboratory studies of the rock and fluid samples to be collected, together with related in-hole measurements, to better forecast reservoir performance, condition, and longevity.

Drilling for research purposes is recognized worldwide as an important and necessary tool for advancing understanding of geothermal and related earth-science issues. A U.S. program is in place under the aegis of the Interagency Coordinating Group (ICG), which consists of the Department of Energy, National Science Foundation, and the U.S. Geological Survey. Each agency is responsible for initiating and funding drilling projects that relate to its own mission, and the ICG provides a mechanism to integrate the interests of all participants. 